\title{
Pareceres juridicos en asuntos de indias
}

(Conclusión)

Parecer de los PP. de la Compañía de Jesús, Juan Sebastión, Esteban de Avi. la, Manuel Vásquez, Juan Pérez Menacho y Francisco de Vitoria, dado al Virrey D Luis de Velazco, sobre si es lícito repartir indios a las minas que de nuevo se descubrieren. 1599.

Por parte de su excelencia se preguntan las dudas siguientes:

La $1^{\text {\%̆ }}$ si es lícito dar indios para minas de nuevo descuviertas o que adelante se descubrieren siendo útiles.

2 quantos y en quanta contidad \$ærá lícito que se den para las tales minas.

$3^{\text {o }}$ de que lugares $\mathrm{y}$ de quanta distancia será lícito enviar los yndios $\alpha$ las dichas minas.

$4^{\circ}$ si será lícito quitor yndios de los trajines، y labranzas para enbiallos $\alpha$ las dichas minas.

5 - - si será lícito quitar de algunas minas no provechosas los yndios que están en ellas ocupados y embiallos a las dichas minas diz nuevo descubiertas o que de nuevo se descubrieren, siendo útiles.

Ante todas cosas se ha de suponer que aquí no tratamos si es lícito compeller indios a la labor de las minas porque esto no se nos pregunta, sino si será lícito dar indios para nuevas minas de nuevo descubiertas, o que de nuevo se descubrieren a lo cual decimos: lo primero, que no se puede repartir lícitamente ni sin deservicio de Dios nuevo número de yndios para las minas, aunque estas se hayan descuvierto de nuevo o con el tiempo se descubrieren; lo qual se prueba, lo primero. Por la mucha dificultad que siem. pre se ha tenido el justificar el compeller yndios ynocentes para la labor de minas, pues vemos que hombres muy graves y doctos assi en este reyno como en España lo han reprovado como ylícito e ynjusto y algunos que han dicho que se puede permitir, $\alpha$ sido con talles limitaciones y condiciones que, por ser esta muy dificultosa de guardar en la práctica, en sustancia si el decir que no hera lícito $y$ de tres hombres graves que, según se dize, fueron deste parecer, el uno se desdixo de palabra y el otro que fué el Arzobispo Locysa, en su testamento declaró como avía escrito al señor visorrey don Francisco de Toledo que el dicho Arzobispo no entendió que avían de compeller los yndios, por ser contra su libertad, y le avía pedido lo rremediase, y por vier que no se rremediava avía escrito a Su Magestad y a su Real Consejo de Yndias suplicándole mandasse rremediarlo, y porque con esto todarvía tenía escrúpulo de conciencia de nuevo declarava y declarói que no tenía por lícito compeller los yndios para las minas, de las quales palabras paresce que bien mirado nunca fué el Ârzobispo Loayza de parescer que se compeliesen los yndios, sino de que se admitiesen los que de su libre voluntad quisiesen alquilarse para travajar en las minas etcétera; $3^{\circ}$ que el padre Joseph de Acosta, si bien se mira, en el libro tercero de Procuranda salute yndorum $c$. 18. en realidad de verdad no lo da por lícito; porque hacia el fin del capitulo dice que ni quiere rreprovar la sentencia que afirma ser lícito, ni poner 
nuevas condiciones para que lo sea, sino solo repetir las que otros an puesto y después de averlas teferido concluye que si se guardan como conviene y como las propusieron varones doctos paresce se puede tolerar que vayan los yndios a minas; pero si no se guardan, $y$ los yndios son tratados rigurosamente como esclavos, cada uno mire por si como quien ha de dar cuten. ta $\alpha$ Dios, y pues que es cierto que estas condiciones no se guardan por la mucha codicia de los mineros, no obstante las ordenanzas que en razón de esto con tanta prudencia y zelo cristiano an dado los señores virreyes; siguese claramente que el padre Ácosta no dá por lícito compeller yndios para las minas todo lo qual se confirma considerando el escrúpulo que siempre se ha tenido de forzar yndios para las minas, si no es de pocos años a esta parte, que parece que la continuación del abuso ha quitado este escrúpulo; porque antiguamente no se davan yndios para minas compelliéndolos, sino de su libre voluntad, lo qual ultra de afirmarlo hombres antiguos en la tierra, se collige de algunas cédulas de Su Magestad, como parece por una de veynte $y$ uno de diciembre de S.M. para el Señor Virrey don Antonio dis Mendoza, donde se refiere que los yndios del collao pidieron a Su Magestad les concediese que en lugar del tributo de ropa y otras cosas que pagabon les: diese licencia para trabajar en Potosí a su modo, sin español que les fatigasse, dóndoles los ynstrumentos necessarios, y que no travajasen en el tiempo de las sementeras que eran tres meses y que andarian seis cientos yndios en la labor y vemos que Su Magestad no se atrevió a concederlo sino que lo rremitió al Virrey que entonces venía y le mandó se ynformase si todos venían en ello, y que aun en caso que todos viniesen en ello mirase si era cossa que se podía hazer sin daño de su salud y conservación, y que lo tratase y consultasse mucho y le ynformasse de ello, $y$ en el ynterin no aviendo ynconveniente condesendiesse con los yndios; $y$ en la ynstrución de los comiscrios en el capítulo 15, dice, que se havía tratado si se labrarían las minas con esclavos que se enviasen de España o con yndios, no forzándolos sino de su voluntad, o si sería mejor darlas a caciques o españoles y el capítulo 16 y 17 donde se trata del oro $d \in$ Chile, en hablando de yndios dice, que sea sin agravio suyo y con ynteres, $y$ su voluntad y también nos han ynformado personas fidedignas, que aviendo escrito una o dos vezes el Señor Virrey don. Francisco de Toledo a Su Magestad si se servía de que compeliese a los yndios para las minas, no tuvo respuesta, $y$ escriviendo por tercera vez que si Su Magestad no respondía tendría esto por respuesta de que Su Magestad no se servía de ello y así el no compelería de ay adelante $\alpha$ los yndios, y con todo esto no tuvo respuesta con ser un negocio de tanta sustancia para Su Magestad.

Lo $2^{9}$ se prueba por que el forzar hombres para la labor de las minas los legisladores gentiles lo tuvieron por un género de dura servidumbre tan contrario a la libertad del hombre, que ningún hombre embiaban sino es por vía de martirio o por culpas gravísimas como consta en la ley illícitas ss. veritas, de officio praesidis, ley ad tempus, capítulo de infamibus, y la ley aut damna inter eos, de poenis, la qual pena es tan grande que con admitir el derecho canónico algunas del derecho civil para castigar delictos muy graves de eclesiásticos, nunca ha admitido ni admitirá esta, como lo nota Gerónimo Zanetino, in Tractatu De Diferentiis inter ius canonicum \& civile, differentia 176, a lo qual se llega que ultra del trabajo que de suio tiene el labrar minas ay nuevos ynconvenientes para los yndios die malos tratamientos con que son vexados de los mineros, dándoles tarea demasiada y azotóndolos algunas vezes sino las cumplen, sin bastar $\alpha$ estorvarlo las ordenanzas que prohiben semejantes agravios. Las muertes, los grandes peligros a que se 
ponen bajando y subiendo por escaleras movedizas de cuero torcido donde en desviando un pie suelen caer y hazerse pedazos, llevando algunas veces acontece derrumbarse alguna mina y quedar enterrados vivos número de yndios hoyéndoles dar vozes por la parte de afuera sus hijos y mugeres sin poderlos remediar, y quando bienen a descubrillo hallarlos ya muertos: assi mismo se le rrecrecen inconvenientes de la distancia de comino que algunas vezes es de ciento, veynte y treynta leguas y mas, de todo lo qual resulta gran disminución en los yndios como se ve por experiencia y por ser tan exesivo este travajo de labrar minas como se vee en el imperio Romano que con tener minas en muchas provincias $\alpha$ el sujetas, no forzaba $\alpha$ los inocentes a labrarlas antes en la ley ${ }^{\alpha}{ }^{\alpha}$ tit. metallariis, libro II, se dice claramente que la labor de las minas era voluntaria, las palabras son estas: quicunque metallorun exercitum vellet affluere (id est, vt ait glossa, quicunque velit esse metallarius) is labore proprio \& sibi reipublicae commoda comparet itaque si quis sponte conduxerit $\&$, y en las leyes, de España, ni de Partida ni de ordenamiento ni recopilación, no se hallará cosa en contrario.

Lo $3^{\circ}$ se prueba, porque como dize Soto (Libro $1^{\circ}$ de Justitia et Jure, $\alpha$. $1^{9)}$ quando un príncipe tiene debajo de su corona diversos reynos para que las beyes que da a cada reyno sean justas, se requiere que sean en pro y utilidad del mismo Reyno como las diera el que fuera príncipe de solo aquel reyno; porque en este derecho y no en mas sucede el príncipe que tiene diversos reynos devajo de su corona, y pues el forzar tanto minero de yndios a las minas no es en utilidad de este reyno pues redunda en tanto detrimento de los yndios que son gran parte del, síguese claramente que siendo Su Magestad bien ynformado no querrá dar leyes y hordenanzas con detrimento de los naturales deste reyno, aunque sea en utilidad de los reynos de España; de todo lo qual se ynfiere, que no será lícito dar nuevo número de yndios, aunque sean para nuevas minas, antes nos parece que el estado de las cosas está de manera que si Su Magestad y su Real Consejo viera por vista de ojos lo que los yndios padecen en la labor de las minas, antes trataran de moderar el número de yndios que van a ellas, pues solo $\alpha$ Potosí van trece mill yndios, que no acrecentarlo; y assi el Padre Acosta en un parescer que dió al qeñor don Froncisco de Toledo dice ser negocio de mucho escrúpulo embiar tan grande número de yndios a las minas, a lo qual ayuda mucho el estilo de Nueva España donde los yndios que se enbian a las minas son en mucho menor número que en este reyno, y de partes mas cercanas que son como de diez a doze leguas o poco mas.

Lo $4^{\circ}$ nos parece que dado caso que fuera lícito compeller nuevo número de yndios a las minas no convenía en razón de buen govierno; porque una de las cosas que principalmente ha de pretender el governador es la conservación y augmento de su república, como lo enseña Âristóteles 8, ethicorum c. $10 \&$ libro $3^{\circ}$ politic c. $4 \& 5^{\circ}$ y Santo Tomás en el Opúsculo De Regimine Principum, desde el capítulo 12 hasta el 15, y compeller más número de yndios a minas es contra la conservación y augmento de este reyno y contra el pro de los Reynos de Castilla; quie esto sea contra la conservación y augmento de este Reyno, vése claramente, pues los yndios se van disminuy'endo y consumiendo cada día de manera qua a este paso se consumirán de suerte que apenas se hallen yndios para enbiar a las minas, de lo qual se vee claramente que también redundaría en daño de los Reynos de España pues dessarian cassí del todo los quintos de Su Magestad y en gran parte cesarían los tributos de los yndios.

$\mathrm{Ni}$ paresce medio conveniente ni justo disminuir el número de los yn. dios que se dá a las sementeras y guarda de los ganados, para acrecentar. 
los a las minas, siendo como es cosa mas necesaria la labor de los compos y guarda de los ganados que la labor de minas; pues lo primero es precisamente necescrio para el sustento de la vida humana y no la plata, porque en caso que no la ubiera con trueque y cambio que son de iure gentium, se podría sustentar una república; $\mathrm{y}$ por esto los antiguos romanos hicieron tanto caso de la agricultura, y don Dionisio Rey de Portugal llamaba a los labradores nervios de la República, y asi vemos el cuidado que se tiene en España de la labor de los campos y cría de los ganados y en razón desto el Rey Phelipe Nuestro Señor en una pregmática nueba dió grandes inmunidades y franquezas a los labradores, assí en sus personas como en los cosas pertenecientes a la labranza, parte de lo qual le estava antes concedido por el Rey don Juan Segundo y por los Reyes catholicos Don Fernando y Doña Isabel, como se refiere en la Nueva Recopilación, libro $5^{\circ}$ tlo. 17, Jey 6 y en el libro 8 tlo. 13, ley 25; y con ser España tan alarvada de minas de oro y plata (libro $1^{\circ}$ Machab, 8) roras vezes se labra alguna mina por juzgar de quanto más fruto será para el Reyno la labor de los campos que no de las minas, y en disminuyéndose los yndios que se dan para sementeras y ganados, creciendo como crecen de cadá día el número de los españoles en este Reyno, habría grande carestía de mantenimientos que es uno de los maiores daños que puede aver en una república.

De aquí se infiere, que tampoco será justo quitar yndios de los tragines para echallos a minas; pues los tragines son de mantenimientos tan necesarios para la conservación del Reyno.

Lo que en esto se podría hazer es, que cunque sería justo y cun al parescer necescrio que se moderase el número, de yndios que al presente va a minas; pero en caso que los governantes no hayan de disminuir este número, podrion enbiar a nuevas minas ricas quitándolos a las que en Potosí están ya muy pobres y muy difficultosas y peligrossas de labrar por su mucha profundidad, teniendo en esto atención al util y comodidad de los yndios trocando los quje van de puestos mas lexos, repartiéndolos para las minas mas cercanas y de temples mas conformes al de los yndios.

Ni obstan a la resolución dada algunas razones que en contrario se suelen alegar. Lo $1^{\circ}$ que cessando en este reyno la labor de minas cessaría el comercio con los reynos de España y por el consiguiente la justicia, paz y religión; pues no ay en esie Reyno otros frutos de importancia mas de la plata, que convide a los españoles a venir acá con tanto trabajo y riesgo, ni con que premiar a los que mantienen la tierra en paz y justicia y religión cris. tiana.

Esta razón no basta, lo primero; porque con el número de yndios que al presente labron lasi minas nos conservamos en paz y justicia y en 'fee y religión y culto divino. Lo $2^{\circ}$, porque la fee assi como no se ha de introducir con violencias, tampoco se ha de conservar con ellas, antes enseña la esperiencia que muchos yndios por miedo de las minas y de otros muchos travajos que cargan sobre ellos se esconden en guaycos donde no tienen quien los enģ⿰彳亍⿱日一 latrias y ritos antiguos, y ni reconocen rey, ni acuden con sus tributos.

La $2^{\circ}$, que con la plata que va deste reyno se sustenta y defiende en gran parte la fee en España. A esto se responde, que no se presume ser voluntad de Su Magestad que acudon los yndios con tanto detrimento suio $\mathrm{Y}$ disminución a la maior parte de los gastos que se hazen en España y defensa de la fee, ni ay razón que dicte que están más obligados a esto los yndios que negros, horros o mulatos, o españoles pobres que ay en este reyno; y pues la sede apostólica los releva de otras cargas y obligaciones 
eclessiásticas mucho mas ligeras, por ver con pecho de padre prudente y amoroso que son planctas tiemas en la fe; justo será que esta carga de la defensa de la fe no cargue toda sobre los yndios, pues no están más obligados que otros a la defensa de la fee con tan notable detrimento en sus haciendas $y$ personas.

La $3^{a}$, porque lo manda Su Magestad del Rey Nuestro Señor en tres capítulos de cartas escritas a los señores Virreyes, Conde del Villar, Marqués de Cañete, y bien se cree que Su Magestad lo habrá primero consultado $Y$ mirado la justificación dello.

A esto se responde que en cosa donde se siguen tan grandes ynconvenientes no es cosa nueva obedecer el mandato, y suspender la execusión hasta que el superior sea mejor ynformado $y$ el derecho asi lo dispone $y$ de lo contrario se seguirían notables ynconvenientes, especialmente, pues el Rey Nuestro Señor tiene mandado a sus virreyes que quando sus reales mandatos se fundaren en siniestra relación, o fueren de cosas que tuvieren difícil execusión, que ésta se suspenda y quanda no obiera tan expresa voluntad de Su Magestad la razón natural y la virtud de la esperiencia dictara que convenía suspenderse la execusión, y que el mandato de Su Magestad se funde en relación diminuta, consta de su real carta para el señor Conde del Villar, donde $\mathrm{Su}$ Magestad refiere que le fué hecha relación de las muchas minas que cada día se hyban descubriendo y de la embriaguez y ociosidad de los yndios y de otros defectos de que son notados, y no se le hizo relación a Su Magestad de quan disminuidos y consumidos están los yndios، y que cunque de suio son poco amigos del trabajo y haraganes, pero de hecho están muy bien ocupados en muchos asientos de minas en tragines, en mitas y la labor de los campos guarda de los ganados, serbicio de los tombos, y de los obrajes de paños, y chasques aderezos de caminos, y puentes, edificios de las casas y templos de manera. que para cumplir el número de los que están señalados para las minas, es necesario algunas vezes embiar yndios de muy poca hedơd y algunas vezes es necesario poner en los tambos yndias que sirban por falta de yndios varones $y$ fuera de los que por orden de goviernadores se ocupan en las cosas dichas hay mucho número de yndios que de su voluntad se ocupan en servir a españoles y en oficios de sastres, zapateros, $\delta$., pues ¿quién puede dudar sino que si Su Magestad fuera ynformado de estas ocupaciones no mandara que los ocuparan de nuevo en minas, siendo esta ocupación tan trabajosa y peligrosa como queda dicho especialmente, pues tantas vezes con zelo de príncipe cristiono encorga a sus virreyes y governadores la defensa, buen tratamiento de los yndios y su acrecentamiento, especialmente que Su Magestad en los dichos capítulos no manda expresamente que las minas nuevas se labren, acregentando nuevo número de indios y asi su real mandato se ha de entender en la forma que sea menos dañosa para los yndios.

De lo dicho consta la respuesta $a$ las demás dudas y assí, no se responde a ellas más en particular -esto sentimos remitiéndolo a otro mejor parescer, en el collegio de la Compañía de Jesús de Lima, 16 de henero de 1599 años. Juan Sebastián - Estevan de Avila - Manuel Vásquez - Joan Pérez Menacho - Francisco de Victoria. (Rubricado).

A. de I. 


\section{MEMORLAL del P. Alfonso Mesía Venegas, sobre la Cédula del servicio personal de los indios. 1603.}

Cerca de la cédula de S.M. Y demás despachos que tratan del servicio personal de los indios, se pregunta qué obligación tiene el Señor Virrey á su cumplimiento, y qué es lo que de dicha cédula se podrá cumplir o dejar de cumplir con buena conciencio, supuesto el estado que de presente tienen las cosas de este reino. siguientes:

Doce son las cosas que S. M. prohibe en dicha cédula, que son las

Lo 1:-Que no haya repartimientos de indios para los campos, edificios, guarda de ganados ó para otras cosas semejantes.

2 '-Que no se eche a indios tributos en servicio personal, en manera alguna.

$3^{\circ}-$ Que en ninguna manera se permita ir indios á trabajar en obrajes de paños ó ingenios de azúcar de españoles, aunque digan van de su voluntad.

4:-Que no se carguen los indios con ningún género de cargas, por ninguna persona.

5:-Que no se repartan indios para las chácaras del Cuzco, Charcas é otras partes, ni los obliguen a perseverar ó quedarse en ellas, si no fuere de su voluntad.

6.-Que no se traspasen los indios con las chácaras á otras granjerías, en cuyo beneficio sirven.

70-Que todo se guarde ni mós ni menos en las viñas y olivares.

$8^{\circ}-$ Que lá pesquería de perlas no se haga con indios.

9:-Que en ninguna manera \$ミ den ó repartan indios a minas, de cualquier metal que sean.

10-Que, por consiguiente, se quiten todo género de jueces repartidores para haberlos de repartir.

$11^{\circ-Q}-Q$ le las tasas, que parece están cargadas para los indios que van a las minas de Potosí, si fueren excesivas y no hubiere otro inconveniente, se moderen, y se informe a $S$. M. de lo que en esto se hiciere.

$12^{\circ}-$ Que las minas no se desagüen con indios, en cuanto fuere posible.

A tres puntos se puede reducir la fuerza que hace la voluntad de S.M. en la ejecución die sus Reales Cédulas. El primero, que de tal manera vá trabada esta ejecución en la perpetuidad y conservación de estas provinciás y con el curso de las cosas de que depende esta estabilidad, que cuando encarga y manda S.M. en todos los puntos más sustanciales de su cédula, que se acuda y que se mire por la conservación, propagación y augmento de los in. 
dios, dice quie no se pierda de vista ni se deje la de estos reinos, como cosa tan forzosa y trabada con la primera y de que depende la una de la otra.

Lo segundo, manda asimismo que desagravien los indios de las injusticias que se les hacen en Potosí y en cualquiera otras minas, pero de tal manera, que se entienda que no ha de cesar su labor, pues por ella están en pié tantas cosas del blen de la cristiandad y sus reinos, de suerte que si la labor de los indios hubiese de descaecer en notable parte, no es voluntad de S.M. que se ejecuten sus cédulas.

El segundo punto es que, encargando la ejecución de ellas en las últi mas palabras de la cédula, lo hace con dos limitaciones: primera, remitiendo á V.E. el añadir ó quitar lo que le pareciere, no obstante lo dicho en la cédula segunda, que advierte á V.E. en lo que dispusiere no tenga inconveniente de consideración ni cause sentimiento ni descontento general, no novedad de importancia, $y$ que ofreciéndose tal inconveniente, que se puedá tener lo contrario, y se prevenga lo que fuere menester para que se consiga lo que se pretende. De donde se infiere que, si no se pueden prevenir, no es voluntad de S.M. se ejecute la cédula.

El tercer punto es el que se saca de la cédula particular que tiene $\mathrm{V}$. E., que le remite S.M. en todo y por todo este negocio, y se le dó plena facultad para hacer en este caso según el estado presente de la cosa, pues tales razones podía haber acá, que conviene no tratar della.

De lo dicho saco una conclusión: que si se ejecutase esta cédula, se toparía con todos los inconvenientes dichos, que previene en ella S.M. Y no quiere se rompa con éllos.

Pondríase a riesgo conoscido la perpetuidad y conservación de estas provincias; causaría sentimiento y general descontento en todo el reino, que darían cuidado de toda importancia. Esto se prueba así: cesaría casi de todo punto la cultura de las tierras, la crianza de los ganados, la labor de las minas, en las cuales cosas están situadas la vida, hacienda y honra de los españoles deste reino. Luego justormente se saca la conclusión dicha.

Y que esto cese, muéstrase así: cuatro medios da S.M. en su cédula, que son generales para obvior los inconvenientes propuestos: primero, que compren negros los señores de las haciendas, tierras, ganados y minas, etc., y se sirvan dellos; segundo, que se ayuden de mulatos, mestizos, esparioles ociosos y gente que en la república se llama perdida; terceró, que obliguen las justicias $\alpha$ los indios $\alpha$ que trabajen y salgan a la plaza, y se alquilen como hacen en España, y que se les tase sus jornales, para que esto tenga menos dificultad; cuarto, que estando los indios lejos de los asientos de las minas, tierras de labor y guardas de ganados, se pueble cerca dellas, para que con más comodidad salgan a las plazas, $\mathrm{y}$ se les obligue al trabajo por Peste medio, que se juzga más conforme a su libertad.

Mirados bien estos cuatro medios, ó son dificultosísimos, ó llenos de mayores inconvenientes para los indios y la mísma república, ó de todo imposibles.

El primero, que se compren negros para tantos y tan diferentes ministerios y siervicios téngolo por peligrosísimo al reino, pues esta gente es de suyo atrevida y libre, poco temerosa de Dios y de su Rey. Veróse oprimida y trabajada con el trabajo, y todo debe causar un temor moralmente cierto de algun motín ó alzamiento entre ellos, pues los pocos que hay en Lima dieron que hablar en esta materia; y en España, en ciudades populosísimas, como Sevilla y otras ha sucedido esto, nascido de las mismas ocasiones, en que se topaban en esta gente estos malos intentos y muchas razones para tenerlos, $y$ en este reino son mayores que en ningún otro, pues si entrase un inglés en 
el Callao, bastaban dos ingleses de los que están entre nosotros para darles la tierra, alzándose con los negros, y cuatro españoles desalmados lo podrían emprender y cada día se topa quien tenga ómimo para cometer semrajantes maldades. Y ultra de esto, llenorían la tierra de pestilencias, por ser esta gente muy subiecta á ellas, y si alguna ha venido á este reino, de sarampion y viruelas, más ordinarias de las que hasta aquí solía haber, ha sido mal traído de los negros que han entrado en él. Y dado caso que esto tuviese todar seguridad, ¿cuántos hay en el reino, de haciendas muy gruesas, que puedan comprar esclavos para ellas; sino que, con toda la ayuda que tienen en los indios, es al cabo del año lo comido por lo servido. Los más labradores son gente pobre, y en Potosí no hay ocho mineros ricos, y ésos se llaman ricos, porque sus haciendas son grandes, $\mathrm{y}$ no porque tengan descanso de plata, que no hay tres que no estén adeudadísimos y todos perdidos. Item, cuando, hubiese posible para ello no lo avia de parte de los negros y del plazo del año que se les dá para prevenirse dellos, porque es necesario irlos á comprar fuera del reino, que según los mercaderes que andan en este trato, y de los navios que corren en él, son muy pocos, y aunque se multiplicorsen en tres portes mós, no podrían dar en muchos años la tercera parte de los negros qui pedía la labor de las cosas dichas. Item, cuando no bastara ninguna de las cosas dichas, no son los negros para las minas, que en cuatro días se morirían, por el gran frío que en todas hay, y por trabajar muchas veces en agua, y hasta el día de hoy no hay minero rico ni pobre que haya echado negro en ellas, por gran audacia que sea la suya, si no es para los ingenios, de los que se llaman morteros y para cerner metal, es cosa certísima que en cualquiera otra ocupación se morirían luego; pues ó este paso se podrá ver y discernir en lo demási ni son tampoco para sementeras, guardas de ganado, etc., por muchas razones.

Lo segundo, de los mulatos, etc., no es cosa de consideración, que toda esta gente es muy poca, y no se juntarón a arar ni cavar, ni como se dijo de los negros, no podrán servir en las minas, que piden gente tan hecha en trabajo como los indios, y tan delgada en sus vestidos, que pueden bajar y subir por partes que se andan en el cerro tan angostas y cerradas, que apenas pulede pasar por ellas un indio, caminando como una culebra; y cuando en el cerro el día de hoy entra un español, una o dos veces, sin cargó ninguna, sino a visitar las minas de su amo y hacer trabajar en ellas, es una gran cosa y que no lo hacen todos, y á este español, que es tan solícito, le dan 2 ó 3 pesos.

Lo tercero, que no se repartan indios, sino que los obliguen las justicias á que se alquilen en las plazas, etc., no es factible esto, por dos razones: la primera, porque los indios que trabajan, pongamos ejemplo en Lima, et sic de reliquis, se traen de la sierra, de veinte, treinta o cincuenta leguas de aquí, como son de Guarochirí, Yauyos, Guamantanga, Santa, Atavillos, Piscas y Antapircas; ¿pues qué órden se ha de dar para hacerlos salir a las plazas, ó quién los podrá mandar venir y alquilarse con efecto, pues oún cuando vienen los indios por sus mitas, y los traen sus cxciques y los entregan para repartirlos por su número y cuenta, falton gran parte dellos. De donde se puede colegir los que vendrón o parecerón en la plaza, cuando estén sujetos á presentarse con este número y cuenta, y los que los han de envior, que son los corregidores y caciques, los querrán para sí y para sus granjerías, y los darán a sus mayores amigos y ó los que más pueden, y será certísimo que padecerón en general y en particular los pobres, $y$ será todo una confusión. 
El sagundo inconveniente que esto tiene es: que habría cada día mil pendencias en la plaza sobre alquilarlos y quererlos llebar cada uno; y serát fuerza haberlas, pues el tener entonces indios dependeria de la mejor maña y mano que cada uno se diere a llevarlos, y la necesidad é interés dellos es tan grande, que como suelen los hombres por cosas de menos peso y consideración que ésta aventurar las vidas, se pueden justamente temer y prevenir las pendencias que de esta ocasión podrían resultar. En España tiene esto diferente razón, que hay siempre quien ruegue, con su trabajo; ahí siem. pre sobran personas para todas las cosas.

Lo cuarto, de que se hagan pueblos y se pueblen en ellos los indios necesarios para las labores de tierras, minas, etc., cuando no hubiese los inconvenienies que acabo de discir en el modo de repartir los indios, hablando en general, son muy grandes los que se le harían á los indios; primero, porque si los mudon á otra parte, es desterrallos de sus patrias, privalles y desterralles de sus tierras, obligalles á que dejen sus casas é iglesias y que hagan otros daños, que no se pueden reparar en ninguna manera, porque el destierro de sus patrias y deudos es forzoso, el desamparo de tierras necesario, el haberles de dar justa recompensa imposible, porque el día de hoy estón repartidas todas las tierras del reino, y es cierto que no se hallarán ningunas vacas para sitio de los dichos pueblos, labranzas y crianzas de los inciios que en ellos se poblaren. Principalmenie, que habiéndose de fundar cerca de los puestos y valles donde se siembran las tierras, las que hoy tienen dueño, $y$ entiendo que no hay palmo della en el reino que esté sin éi, las iglesias y sus casas, y gasto en pasarse y traginar sus mujeres é hijos, todo ha de ser a costa de los pobres indios, si no es que S.M. quisiere hacerlo y gastar en esto más de un millón. Item, es cosa sin duda quil se acabarían los indios, sacándolos de su natural y siendo fuerza en muchas partes, para conseguir el intento dicho, pasar los de la sierra á los llanos, como se ha de hacer en Lima, que todo su servicio le tiene de la sierra; es cierto que les es dañosísimo á los indios, y en este reino, en pocas leguas, es tanta la desigualdad de los temples, que en más o menos frío, más o menos calor, se experimentan extremos. Item, sería despoblar unos corregimientos del reino por hacer otros; obligar a los encomenderos á nuevos salarios de corregidores, y partir los que hay acá no se debe hacer, pues con tener a ochocientos y mill pesos de salario, se juzga por no competente, y les parece ó los corregidor es que non rcceperunt mercedem Iaboris proprii, y que pueden tratar y contratar y granjecrlo y suplirlo con otra vía. Lo mismo se diebe entender de los doctrinantes, setc. Item, habríase de cargar el trabajo que D. Francisco de Toledo echó a un indio de siete a siete años, en solos los que se poblasen en estos pueblos, pues si se pone en ellos número de indios que lleve la mitad de un año, en éstos cargaría cada año, y si se duplicase, les cabría de dos á dos años y pensar que se podrían poblar pueblos con tres, ó cuatrocientos indios ó la mitad, sin que de todo punio se mude el Perú, téngolo por imposible, pues el día de hoy hay la mitad menos de gente de cuando D. Francisco de Toledo les señaló la séptima parte, y así hay más de las tres partes de indios menos; y si las tres que quedan se pueblan en las partes necesarias para las labores y guardas del ganado, etc., se habrá de despoblar los pueblos que agora las tienen hechas, que tiene un millón de inconvenientes y no es factible.

De lo dicho se collige con claridad la dificultad grande que tienen los medios que S.M. propone, y que poniiéndolos en ejecución, caerá de golpe este reino, faltará la comida y la plata, que lo uno conserva la vida y lo otro entretiene la gente, etc.; y así, me parece que obstando a la ejecución de la 
Real cédula las cosas y dificultades propuestas, no es voluntad de S.M. que se ejecute, sino antes consta y parece ser la controria.

Presupuesto y asentado que sea así lo que tengo dicho, no pretendo que qe queden las cosas en el sér que están, sino que, conocida la dificultad que tiene su remedio, sirva siquiera de que se sienta su estado y couse compasión la miserable gente que lo padece. Podemos considerar a este reino, como una casa atormentada con un gran temblor, derribada la mayor parte della, y la que queda en pié, tan sentida y con tantas listas de aberturas, que si el dueño della, lastimado de verla así, quisiese remediarla y volverla á su primer estado, había de ser con riesgo de derribarla toda y levantarla de nuevo. Pero si no quiere aventurarse á tanto gasto y pérdida, procuraría llenar los vacíos de las aberturas y fortalecerla y enlucirla lo mejor que pudiese, y así quedaría disimulado su daño y más segura su vivienda.

Querer poner en su punto y perfección este reino, después del temblor que ha pasado por él (1), de tantos daños recibidos en los indios y estar menoscabados, es casi imposible, y para hacerse, hase de desencuadernar y entablar de nuevo, con riesgo de perderse todo. En lo que se debe ponjer el blanco es en remediar los particulares abusos que en todo género y uso de los indios hay en sementeras, guardas de ganado, trajines y minas, en que padecen los misereables agravios é injusticias, dignas de prevenir y castigar. $\mathrm{y}$ vélas tocando todas las que entiendo, $\mathrm{y}$ sus remedios.

\section{SEMENTERAS}

La labor de las tierras y guardas y crías de ganado, es lo que en primer lugar ha de ser favorecido para los indios, pues, en general, para todos es el beneficio que dello resulta, y la agricultura es principio del acrescentamiento del linaje humano, el cimiento de todos los oficios é industrias, y ella sin ellas podría en manera alguna pasar, y ellas sin ella no; y por esta razón han hecho tan gran caudal de los labradores todas las naciones. Don Dionisio, rey de Portugal, los llamaba los siervos de la república, $\theta$ el Rey D. Felipe II, Nuestro Señor, de gloriosa memoria, en la pragmática que hizo en el año de 97, los favoreció con grandes inmunidades y franquezas. Esto supuesto, para que no se les deban quitar los indios, diré los doños que reciben.

1ㅇ--Ei no pagarle los labradores ni darles de comer; cumplen con ellos en acabando de servir su mita, con darles unas cédulas, en que dicen deberles tanta plata, la cual nunca se les paga, ni muchars veces es posible, pues no acierta el indio sino a volverse $\alpha$ su tierra y morirse allá, y deja la cédula a su hijo que ni conoce cuya es ni hace caso della. El remedio que se ofrece es, que siempre que se repartiere la mita en el pueblo o en la ciudad, se dé un pregón, en estando los indios juntos, en el cual se les diga len su lengua á los indios, y en la suya á los españoles, que el español que no les pagare ó diere mal de comer, venga el indio á dar aviso al alcalde que los reparte, y el alcalde mandará V.E. que haga pagar al indio por aquella vez, y reprenda al chacarero; $y$ por segunda vez que se quejare el indio, no les den indios ningunos aquel año, y que para esto no sea menester hacer grandes procesos, sino que en oyendo á los indios y afirmando este agravio dos

(1) Alusión al terremoto de 1600 que asoló la ciudad de Arequipa y su comarca. 
ó tres indios, y no mostrando el chacarero que los pagó ante dos españoles, se ejecute esta pena y se les ponga por el alcalde dos meses der suspensión, si no la ejecutóre. Y para esto, asista siempre con el alcalde al repartimiento de los indios el protector de losi naturales, para que pida en justicia y los defienda.

2:-Los contratos de compañía que se haaen, dando uno las tierras í indios y poniendo otro el pagarlos y su trabajo, etc., son dañosísimos y perjudiciales ó los indios, porque estas compañías las hacen ordinariamente gen. te pobre y que no tiene con qué pagar los indios ni de comer para ellos ni para sí. Y el daño particular en este trato es que, por salir aprovechados aquel año, martirizan los indios, y de día y de noche los hacen trabajar en labrar la tierra y regar. Remedio es mandar al Señor Virrey que, en sabiendo que alguno tiene hecho este contrato, con sus tierras é indios, se les quiten luego los indios, sin que en ello haya réplica; que en esto recibe beneficio gieneral el reino, y el daño que hay es de un particular, que no importa nada.

Suelen algunos recibir mayordomos en sus chácaras y haciendas, concertándose, por una cuota de los frutos, y porque ésta se agrande, v. gr. la sexta ó séptima parte, sácanla del sudor de los indios.-Poner el mesmo re. medio.

Suelen los labradones ocupar los indios que se les dan pora las sementeras, en labrar casas ó en trapiches de azúcar y miel, de lo cual se sigue á la república haber menos sementeras en su comarca y más caros los bastimentos, y los indios que alcanzaron á gozar de este beneficio de tener la comida barata, piérdenlo y corren riesgo en los trapiches de cortarse las manos, etc. $y$, en los edificios, de desgracias que cada día suceden. Remedio: quitar los indios al labrador que se entendiere los ocupa en otra cosa.

Las licencias que se dan á los corregidores para hacer sementeras, sin duda que son con mucho daño de los indios; porque el corregidor toma para ellas el mejor pedazo de tierra, quita el agua á los indios, ocúpalos en su hacienda, y vienen los pobres á ser esclavos en sus mismas tierras y á ser maltratados y ocupados.

Entiendo que generalmente no se paga en el reino su justo jornal á los indios que guardan ganado; podríase remediar con enviar V.E. sus provisiones á todos los corregidores, para que vean cómo se les paga en sus distritos, y para que cada uno junte á los prelados de las religiones y protector y vea en cuál distrito están bastantemente gratificados los trabajos de los in. dios pastores con lo que se les paga, y que avisen \& V.E. lo que juzgaren, para que últimamente mande lo que más convenga al bien de los indios, advirtiendo á los tales corregidores cómo los señores del ganado obligan a los indios á que les paguen el ganado que se les pierde ó les hurtan; y que para esto sea lícito, dicen todos los sumistas que ultra de lo que se paga á los guardas del ganado por pastoreallo en tales y tales puestos buenos, se les ha de pagar algún tanto por asegurarlo de que se perderá, que lo eraminen bien y envíen su parecer.

\section{MITAS}

El útil que dellas hay en este reino es conocido, y para los mismos indios es grande. Diré los daños y agravios que reciben.

El $1^{9}$ es en el jornal: dáseles cinco patacones cada mes y no les pagan la vuelta; v. g. hacen 100 indios un viaje de los Andes á Potosí, y no les dan sino cinco patacones cada mes, desde que empiezan su viaje, $\mathbf{Y}$ 
6 la vuelta de Potosí no les dan nada, y el agravio es conocido, pues no se les paga la comida. Come un indio cada mes media hanega de maíz y chuño (1), que vale cuatro patacones, y un paco (2) 6 alpaca hecho cec,na, que llaman charqui, que vale tres patacones. También lleva harina de quinua y un poco de pescado seco, que serán otros dos cada mes, ya son nueve; luego no se les paga la comida; y no se cuentan ollas que llevan, $y$ sus carneros en que llevan la comida, que si se les muerte uno, pierde el indio siete patacones que vale y ordinariamente llevan para sí cargados uno ó dos carmeros.

$2^{\circ}$-Les mandan aderezar las isangas (3) en que llevan vino ó los cestos de coca y hacer guascas (4) de icho; y por estas cosas no se les paga nada. El remedio de estas dos cosas es que con efecto se asiente que se les pague justamente su trabajo.

$3^{\circ}$-Reciben estos indios gran daño en su propio ganado, que dejan en. sus pastos, porque en sabiendo que el dueño está cousente lo hurta, y no temen a la mujer, y hay de esto mucha experiencia fuera de que pide este ganado mucha asistencia de los indios, y esto cesa con su ausencia y es causa de que parte dello se huya. Reciben el mesmo daño en sus chácaras, porque la mujer puede poco, y hace mucho en acudir a sus hijuelos, hilar, hacer ropa, etc.; y así se pierden sus ganados y chácaras por falta de dueño que lo mire $y$ beneficie.

$4^{\circ}$-Reciben daño en sus almas, que como se ausentan los indios tres Y cuatro meses y á veces más de cinco, y estas ausencias son ordinarias, se les olvida lo que saben de nuestra fe, no oyen misa en todo este tiempo, en los caminos cometen pecados, que no harían si estuvieron en sus casas y con sus mujeres, y ellas no menores con la ausencia de sus maridos.

$5^{\circ}$-De estas ausencias reciben daño las comunidades, que van cada día a menos, faltando ó la propagación y generación dellas. No hallo en esto otro remedio sino procurar que las cusencias sean más breves; $y$ esto se conseguiría mandando S.E. que los indios que bajan con ganado de la provincia de los Pacaxes, Omasuyo, Paucar-Colla, Chucuito y las demás provincias que vienen al Cuzco por Coca, se remuden, en llegando á la Provincia de Paucarcolla, Omasuyo, ó Pacaxes, y en ninguna manera sean los mes: mos indios que salen los que suban á Potosí con el ganado y hacienda. Y para que esto tenpa efecto, mande V.E. al corregidor de Sicasica, por donde ha de pasar el ganado forzosamente, que tenga especial cuidado en inquirir si los indios que subieren con sus partidas gruesas de carneros de Potosí, se mudaron en los puestos que he dicho; y si se hallóre no ser así, detengan los carneros y no les dejen pasar hasta que traigan indios de remuda, y con tres o cuatro veces que se haga así, no se atreverá nadie a dorr todo el trabajo ó unos mismos indios, y los miserables tendrán partido el tiempo, de suerte que si en un viaje habían de estar cuatro meses, no esten sino dos con la remuda dicha, y estorbaránse tan grandes inconvenientes $\mathrm{y}$ daños.

(1) Harina de papas.

(2) Mamífero del orden de los camélidos, que habita en la Sierra del Perú. Se le llama también alpaca.

( 3) Cestos de caña. Usance especialmente para pescar camarones.

(4) Voz quechua que equivale á cuerda, soga. 


\section{MINAS}

Supuesto que es razón de dar indios para minas, se ha de hablor como en negocio tolerado por los Reyes, sus virreyes $y$ consejeros, y por los seguros que tienen de sus conciencias con parecer de hombres muy doctos, débese poner solamente en disputa en esta materia $\mathrm{y}$ hacer mucho peso en si convendrá dar indios á las minas que se labran con muy moderado ó ningún truto, como son las de Castrovirreina. Vilcabamba, y Salinas; y supongamos que los indios que van á estas minas son los siguientes: á las de Castrovirreina 1,500 indios de los Aimaraes, Jauja, Chocorvos, Cotas, Lucanas, Tarma y Chinchaicocha, y otras partes, las más lejos 100 lequas. A las Salinas vơn 600 indios de los corregimientos de Chuquiabo, Pacajes, Achacachi, Sicasica, Chayanta, Paria y provincia de los Lipes; estón los más lejos 85 leguas. A Vilcabamba van 480 indios de la Provincia de Andahuailas, Chumbivilcas y corregimiento de Avancay, y son por todo los indios que von á Bstos tres asientos, 2,665. Son razones para no quitarse: el estar ya asentado; el haberse gastado en labrar las minas y en hacer ingenios las haciendas de algunos mineros; el sacarse al fin alguna cuota cada año, con que se socorre más el reino y S.M. Todas estas razones no tienen fuerza, ni son pa ra que se puedan tolerar ni pasar en estas minas, pues no debe bastar el estar entabladas; que los que tratan de su bien particular en alguna cosa, si por los medios que ponen no lo consiguen, luego la dejan y se apartan della; luego, si los que tratan del bien universal, deben con más razón de continuar lo que no aprovecha ni es útil para el intento que pretenden, pues es mayor el daño que se hace en continuarlo, ¿qué vamos a decis de lo particular a lo universal y común?. Item, hasta aquí han oído los señores virreyes y entendido los graves daños é injusticias que generalmiente se hacen á los indios en toda labor de minas, y se han encogido diciendo que no tienen facultad para quitar ni moderar los indios; agora no sólo tiene S.E. facultad, sino mandato expreso del Rey, Nurestro Señor, para quitar los indios á todas las minas, etc., luego por lo menos se deben de quitor a las inútiles. Ni debe obstar el haber gastado algunos sus haciendas en hacer ingenios, etc., para las tales minas; que el daño de cuatro particulares ó de ocho no ha de preponderar sobre el daño de muchos y á la ejecución de la cosa, cuando conviene é importa, pues juzgando S.M. por conveniente pasar su Real corte á Valladolid, no se reparó en $20,000.00$ que se perdían en la mudanza, y no perderán los mineros de todos estos asientos 300,000, ni perderán más de la calidad y valor de las haciendas que tienen por estar y $\alpha$ fundadas $y$ hechas, que los materiales é instrumentos todos se venderón y aprovecharón en otra parte, ni el reino recibirá daño de consideración, pues en un navío que se piserde en esta mar suele interesar al reino más de un milllón, y no se siente mucho su pérdida ni se echa de ver; y quizas castiga Dios á este reino con tan grandes pérdidas en mares y ríos y sucesos tan desgraciados de pocos años acá, para mostrar que nos quiebra los arcaduces por donde se negocia y corre la sangre de estos miserables indios.

Ni es cosa de consideración que se dejen de sacar cada año de todas estas minas 300 a 400 pesos, pues tienen por contrapeso el daño tan notable que hacen á la conservación deste reino, é importa más a S.M. conservar 3,000 indios, que andarán de mita en minas, que lo que se saca dellas y por lo menos se perdería más en los tributos que dejarían de dar los indios, acabándose con sus vidas, que se ganaría en continuar la cuota que se saca de minas tan flacas, y que cada día lo han de ser más. 
Item, no está obligado este reino á dar todo lo qule tiene hasta quedar exhausto y del todo deshecho.

Item, rigor grande y crueldad sería, y contra derecho natura?, mandar trabajar a un viejo tanto como á un mozo; y esto, no por otra razón, sino porque son menores las fuerzas de un viejo.

Este reino se puede considerar respecto de los indios que están en esta edad; pues, ¿por qué se les ha de dar agora tanta tarea de trabajo como cuando estaba en su juventud, cuando florecían los pueblos de gente, cuando no había tantos españoles que los expoliasen, cuando las labores de minas eron menos $\mathrm{y}$ de labraban sin tanto trabajo, y el fruto era de más grosedad y provecho? Pues por qué agora no se les alivia el trabajo, que es sin fruto de consideración?. Y pues hace más fuerza esta razón; decir que lo quiere así Nuestro Rey y Señor, digámoslo e instemos á V.E. para que conceda este pequeño beneficio á estos miserables indios. $Y$ si se preguntare si sería buen gobierno y en bien del reino y de los naturales, que estos indios que están en minas flacas y de poco fruto, como son los de Castrovirreina, se pasasen á otras minas ricas que en diferentes partes se van descubriendo, respondo que no hay obligación, mirando el bien de este reino: por: que su bien primario es conservar en paz y en las cosas de nuestra fe y que tenga quien en todas le gobierne, y con lo que le dan las minas de Potosí se consiguie todo esto.

Ni se debe por el bien secundario, que es ayudar al de España y á su Rey y Señor, para la defensa de sus reinos, pues con lo que se saca de Potosí se acude y se ha acudido también suficientemente á esto, y antes que se fundara el asiento de Soocha (1), se gozaba de todos los dichos bienes; y pues no depende de estos asientos y otros semejantes, débense deshacer como medios sin fin del todo justificado; que son degolladeros de indios $y$ naturales, principalmente dando Potosí hoy más quintos que nunca ha dado.

Item, en género de buen gobierno el gobernador está obligado, en conciencia, á moderar cuanto se puedan los trabajos de la república, con notable detrimento de los particulares della; y constando, como consta, que se van muy aprisa acabando los indios y que los trabajos de las minas son insoportables, tienen obligación de aliviarlos y reparar esta violencia de trábajo, moderando las minas salten inútiles, reservándoles del todo de esta carga y no añadiéndosela, valiéndonos del ejemplo que tenemos en el repartimiento de indios para las minas de Potosí, que por haberlos ida cada día car. gando y no haber tenido ningún descanso, están las provincias perdidás $y$ acabadas. Como verá, el Señor D. Francisco de Toledo repartió 1,000 pará la labor de las minas de Potosí y 100 para suplir faltas de la mita. Vemos que este repartimiento era llevadero y carga que se podía tolerar; pues considerando que en los 32 años que van, á partir de 18 que comienzan a tributar, hasta 50 que acaban, sólo le cupiese de venir dos veces en la vida a estas minas a cada indio. Fuése disminuyendo el número de la gruesa de los 16,000 indios, que había de haber sido causa para que se les relevase y disminuyese el número de 1,100 que se les habían repartido; y en lugar de hacer esto, se les repartieron y añadieron otros 1,100, con que se les repartió la séptima parte, y la Provincia de Chucuito se ha ido acabando de gente y adelgazando de suerte, que es compasión mirarla. Lo mismo digo de los indios que están repartidos á estas minas inútiles, que tienen exhaustos y acabados sus pueblos, y en lugar de tratar el aliviarlos y descansarlos, propo- 
nen a V.E. los echen en nuevas minas, donde se acaben de acabar y se concluya con todo de una vez.

Item, los indios del Perú no están obligados a beneficiar cuantas minas hay; que los de Nueva España, con estar menos destruidos y dar menos plata á S.M. no labran todas las que tienen, antes se reparten con mucha moderación, y previniendo que no vayan de partes apartadas, sino de las más cercanas, y con otras comodidades que en esto se han tenido, por la piedad de los que lo han gobernado, con que está aquel reino más entero que éste.

Ultimamente digo que no es beneficio el que se les hace a los indios en pasarlos a mejores minas con las comodidades que se pueden prometer de mejores temples, más abundancia de comidas, las minas más fáciles de labrar por estar sobre la tierra, etc. Las razones son éstas:

Lo primero, las comidas no serón en muchos días y meses más baratas, porque aunque diéramos que ahora hay mucho trigo y maiz en los puestos que pretenden ser asientos de minas nuevas, en poblándose de gente asi de españoles como de indios, ha de subir la comida por razón de la demas gente que la gastaró, y porque serán menos las sementeras que se harán entonces, que, sin duda, ocuparón más los españoles en otras cosas á los indios de la comarca, y no les dejarán con sosiego en sus casas y en sus chacarillas, y cesará la abundancia de comida, que sólo era abundancia para los pocos que la gozaban y tenían quietud para acudir ó sembrar y labrar la tierra.

Lo segundo, es engaño decir que tendrán menos trabajo los indios, antes se debe figurar mayor, pues sólo trabajan ahora en los asientos donde están en sacar metales y si se diesen á minas nuevas, trabajarían en ellas, y en hacer casas para españoles, y fundar pueblos, y hacer ingenios, y con la codicia que acuden los españoles á los principios á estas cosas, sería muy doblado el trabajo y carga que tendrían los indios; y como los mineros á los principios son siempre pobres, no pagarían $\alpha$ los indios, y vemos que en Castrovirreina no les pagaban sino de cuatro a cuatro meses, en acabando la mita y no sé si de presente se hace así, y sí sé que D. Alonso de Mendoza me dice que sí, y es muy digno de remedio. Y si pedían los indios antes plata para comer, les pagabon en maiz á como quería el español, y si el indio enfermaba antes de cumplir la mita ó se iba, se quedaba sin paga de lo trabajado; y aunque estos jornales de indios que faltaban al tiempo de la paga, hacia D. Pedro de Córdova Mejía que con efecto se pagasen y se pusiesen en una caja, no sé cómo se repartían después ni entiendo cómo se podrían repartir ni dar ó quien los había comprado con su sangre. Y últimamente digo en este punto, que si los indios se hubiesen de mudar de minas no buenas ó otras que lo fuesen, sería processus in infinitum, aunque lo más cierto y sin duda sería ser finito, porque se acaborían más presto los indios. $Y$ así no sería yo de parrecer que se diesen, ni se debe juzgar por voluntad de S.M., sino contra ella, que manda que no se den de nuevo á minas indios, $y$ esto es dar de nuevo, pues los indios que se dieron a Castrovirreina, etc., no fué por sentencia de culpas que no lo es; luego debe cesar la obli. gación si alguna tienen, y débese llamar nueva la que de nuevo se les pidiere, muáándoles á otro asiento.

Para entender bien lo que sobre este punto se dijere, es necesario suponer que de las provincias de Pacajes, Carangas, Paria, Omasuyo, Chucuito, Canas y Canches, y de todo el Collao, lo más lejos del cerro, 150 leguas, van cada año de mita 12,600 indios para repartirse en tres tercios del año, de cuatro á cuatro, y se necesita bajor en ellos los 4,200 de suerte que nun- 
ca falte este número en el cerro, sino que trabajen de ordinario en él. Y acabada esta mita, viene otra, $y$ van a descansar los primeros, aunque el primer tercio que acaba de servir los cuatro meses, les cabe luego á los 2,000 el trabajar dos meses en servir en las lagunas, trajines de metales, servicio de la villa y hospital y minas de Porco (1), que están siete leguas de Potosí. Y para que mejor se entienda el agravio que se les hace á estos indios, y las injusticias que padecen, pondremos ejemplo de lo que pasa $\alpha$ los indios que salen de la Provincia de Chucuito (2) que, repetimos, se puede entender que pasa así á los demás.

De la Provincia de Chucuito salen 2,300 indios cada año para el entero de la mita que hemos dicho. Todos estos van ordinariamente con sus mujeres é hijos, que por haberles visto subir dos vecas, puedo decir que serón todos más de 7,000 almas. Cada indio de éstos lleva por lo menos ocho y diez carneros, y algunos pacos ó pacas para comer; otros de mós caudal llevan sus comidas de maíz y chuño, sus mantas para dormir, esterillas para defenderse del frío, que es riguroso, porque siempre duermen en el campo. Todo este ganado pasa ordinariamente de 30,000 cabezas, y casi siempre llegan á 40,000, y año hubo que se contaron 50,300 cabezas. Pues digamos que no son más de 30,000; éstas con el chuño, maíz, harina de quinoa y cecina Y sus vestidos nuevos, vale todo más de 300,000 pesos de á ocho... (3).

Toda esta riqueza con este carruaje ha caminado á Polosí por sus jornadas, y en distancia de cien leguas tardan dos meses, por no poder caminor más aprisa el ganado ni sus hijuelos, que de seis á cinco años llevan a pie. De toda esta comunidad y riqueza que sacan de la Provincia de Chucuito, no vuelven á ella 2,000 almas, y el resto, que serán 5,000, parte se muere, parte se queda en Potosí.

Otros se van á los valles más cercanos, y la razón que para esto tienen, es que cuando se quieren volver no tienen ganado, ni comida para el camino, y saben que, en volviendo, los han de ocupar los caciques, y corregidores en trajinar y en el servicio de los tambos. Y como en el día de hoy están los indios en este camino real tan solos y trabajados, y hay tantas cargas y molestias, que padecen de los españoles; y también porque, en llegando de Potosí á sus pueblos, como el cacique está apurado, y no tiene indios con que cumplir su mita, y el gobernador le apremia á que la entregue, los vuelve á nombrar fara que vayơn otra vez, y con las mismas obligaciones y cargos referidas, quy quiebra el corazón verlos, pues por huir esto, y redimir su vejación, quédanse en Potosí, donde hacen su voluntad y tienen de comer. Vea V.E. si es servido ahora lo que les pagan á aquestos indios por dos meses que gastan en ir á Potosí, y cuatro que trabajan en las minas, $\mathrm{y}$ dos en los trajines, etc., y otros dos meses en que vuelven a sus tierras, que son diez meses y veró V.E. una injusticia clara y manifiesta, que sólo se les paga á estos indios por estos diez meses, los que son de trabajo para ellos, y con efecto, trabajon cuatro meses en las minas á cuatro reales cada día, y los dos meses que se ocupan en las cosas referidas, á tres reales y medio cada día; pues digamos que se les paga á cuatro reales; seis meses son veinte y seis semanas, y trabajándolas todas, sacando sólo los domingos, á tres patacones, cada semana son 78 patacones. De estos 78 patacones se han de quitar al indio 22, que paga más de tributo al ney por ve-

(1) Asiento minero del Alto Perú, vecino a Potosi.

( 2) Provincia de Chucuito, en el Departamento de Puno, del Perú.

(4) Está borroso el original. 
nir á las minas (cosa de admiración, que por lo que había de ser exceptua do de tributo, por esa misma razón le corgan paga de tributo). El indio que se está en la Provincia paga tres pesos ensayados, y una pieza de ropa qus vale seis pesos ensayados, que son diez patacones, y el que viene á las minas de Potosí paga 18 pesos ensayados, que son 29 patacones, seis rlsales y seis granos corrientes, que con el medio peso ensayado que dan para of hospital y los granos de cada semana, viene á ger lo que paga en Potosí cada año cada indio 32 patacones que sacados de 78 que le dan por su trabajo, viene á quedar el miserable indio con 46 patacones, por diez meses de trabajo que pasa él y su triste familia, desterrados de su natural, dejadas sus casas y tapias, sus tierras perdidas, y gastado el ganado que tenían, y su comidilla en el viaje: que por lo menos valdría do que sacó el indio más pobre de su casr en cameros y comida, etc., más de 100 patacones. Y por esto y el trabajo tan excesivo de seis meses, y los cuatro de minas, trabajando doce horas al día, bajando sesenta, y algunas veces cien estados, donde es unr perpetua noche, pues siempre es menesier trabajor con ccrndelas, el aire grueso y de mal olor encerrado en las entrañas de la tierra, las bajadas y subidas peligrosísimas, subiendo cargado con su taleguillo de metal atado en las espaldas, tardando en salir cuatro y cinco horas por pasos, que si discrepan de poner bien el pié caen cien estados; y que después de haber subido reventando, hallan por abrigo un minero que les riñe porque no salieron mós presto, porque no trajeron mayor carga, que luego en un punto les hacen volver; $y$ que por todo esto y cuatro meses que quedan dichos de peregrinaciones, se les dé solo 48 patacones, ¿á quién no corusa. rá compasión?.

De esta relación se coligen tres daños é injusticias que reciben los indios, muy dignos de remediar.

10 - Es hacerles caminar 150 leguas con el gasto y peregrinación refarida por despoblados y campos, padeciendo grandes fríos, bebiendo coguas malas y encharcadas, y que, cuando llegan al puesto del Potosí, y donde pedía su trabajo algún descanso, se hallan sentenciados á una tarea tan rigurosa, y en acabando con ella, ton rendidos $y$ sin fuerzas, que no las tienen para atreverse ó volver á sus tierras, sino que desmayados y obligados de su necesidad, eligen el quedarse en aquel temple de Potosí, que es tan desigual á los demás del reino, que vienen á morirse y acaborse poco ó poco.

Para obviar este tan manifiesto daño, han dado muchos hombres práct.cos de la tierra por medio que se poblasen junto al cerro de Potosí algunos virlles, $\mathrm{y}$ en ellos treinta y siete mil ochocientos indios, que son tres mitas de á doce mil seiscientos indios, para que de tres á tres años be cupiese á cadu indio el trabajo en el cerro y sus minas. Y aunque Don Francisco de Tolede señaló la séptima parte de los indios, para que de siete á siete años le cupie se á cada uno su vez; pero con la comodidad dicha de ponerlos cerca del cirro de caminos tan largos, y por estar el reino en tal estado, se podrá tener por mejora y beneficio de los indios el no haberles de ccer su vez sino de tres á tres años.

El medio con que esto se había de poner en ejecución es difficultosísimo y tiene mil inconvenientes. Diré algunos diversos, en que han gastado tjempo personas prácticas de esta tierra, deseosas del bien común.

Unos dicen que para entablar esto se sacasen de una vez de cada pueblo de los que acuden al servicio del cerro, y la mitad quedaría triplicada. de suerte que del pueblo de donde salen cada año ciento y cincuenta indios, salyesen de una vez seiscienios, que son ires milas, haciendo primero 
diligencia con los indios y requiriéndolos que los que se quisiesen mudor á Jos asientos que en los valles cercanos á Potosí les tenían preparados, lo dijesen para que fuesien en primer lugar los que dispusiesen de su voluntad. y sirviese esta diligencia para hacerlo sin menos violencia, pues cuando dijesen todos que no querían y se les apremiase, no se les tenía por violencia el forzarles á ello, pues era para su mayor bien y provecho. Y sacado el dicho número de indios con efecto y en la forma dicha de los pueblos y provincias sujetas á darlos, se pusiesen en pueblos cómodos y vecinos al cerro, donde se perpetuasen $\mathrm{y}$ avecindasen.

Contra esta traza se ponen algunos inconvenientes considerables, como sería que se despoblarían los pueblos de donde se sacase el dicho número de indios, y consiguientemente las provincias, por estar el día de hoy tan exhaustas y del pueblo de donde se sacasen seiscientos y cincuenta indios con sus casas y mujeres, no quedaría ninguno, y pocos pueblos podrían satisfacer por entero con esta mita.

A esto dicen que se habían de empadronar todos los indios que hay en Potosí y en todas las chácaras de Chuquisaca y las demás de aquel contorno, por todas las quebradas donde están escondidos los indios, y que destos se habian de enterar en primer lugar la dicha cantidad de las tres mitas.

De esta resolución infieren otro inconveniente, que sería el que recibirían las chácaras de Chuquisaca y de los contornos de Potosí, etc., si se les quitasen los indios, que era quitar el sustento á la tierra, y con él caer todo lo demás de golpe. A esto responden que se pueden dejar en las chácaras indios de Quito, Chachapoyas, Nuevo Reino, y de los valles de Trujillo y otras partes, y con esta traza y disposición se acudiría al bien universal y particular, al de los pureblos y provincias, que viéndose ya libres de mitas, y las chácaras con servicio bastante de indios forasteros, y podría estar todo con mejor ser y concierto y menos males y agravios.

Otros dan por medios para la ejecución de este intento que no se trate de sacar indios de nuevo en la forma dicha, de los pueblos, sino que se empadronen todos los indios que hay en Potosí, que sin duda, hay más de cincuenta mil indios, sin los entrantes y salientes, y de éstos se cumpla el número de las tres mitas, que son treinta y siete mil ochocientos indios, y se les reserve de otro cualquier servicio, poblando por sus parcialidades y comunidades en pueblos antiguos, que el día de hoy están despoblados y sin casi giente, cerca de Polosí; y que á ésto se les diese por cabeza para su gobierno, no caciques ni gobernadores perpetuos, porque éstos son los mayores enemigos y carniceros de sus vidas que tienen, que con el reconocimiento que les haden y vasallaje perpetuo en que están los pob $b_{2}$ indios, no se atreven á tener uno a su voluntad; y como la de los caciques de ordinario sea no sine sed contra rationem, viene á ser que son de su parte más vejados y trabajados los indios que por la de los corregidores y doctrinantes. $Y$ la razón desto es, que como los caciques son perpetuos, nunca se atreven á quejarse dellos, como lo hacen de corregidores y curas, porque temen que al fin ha de pagar lo que dijeron é hicieron contra ellos, pues nunca han de escaparse de sus manos y jurisdicción.

Contra este medio se opone una dificultad, ó por mejor decir, imposibilidad, que por tal la juzgan muchos, de que no hay en Potosí tanta gente, que se pueda con ella satisfacer el intento como se pretende; porque cuamdo haya en Potosí cincuenta mil indios por todos, que es el mayor número que puede haber, de éstos serón los ocho ó diez mil que cada día entran y salen, y los doae mil seiscientos de la mita presente que hon de salir al fin del año, Y más de diez mil que son oficiales y sirven á españoles, que son por todos 
los dichos treinta mil indios; y los veinte mil que quedan se ocupan cada día, fuera de los seis mil doscientos indios que andan ordinarios de mita en el cerro é ingenios, más de otros ocho mil que trabajan alquilados en el mismo cerro é ingenios, casas, beneficios, trajines de metales, traen leña y otros menesteres y servicios de las minas; de suerte que no hay día que no estén de doce á trece mil indios ocupados en las minas y en ministerios y oficios convenientes á ellas condenados solamente á sacar plata.

$Y$ porque entiendo que ha de tener V.E. algunos que positivamente disuadan y contradigan este medio de poblar gente en Potosí, y de la que allí hay en que esté situada la mita de aquel cerro, afirmando que no hay copia de irdios para el efecto de este intento, responderé que no hay más razón pa. ra que sus razones y tanteo satisfagan, que para dar crédito á las de otros muchos con que fundon que esto es factible, y que no foltarán indios en Potosí. Y cuando sus razones sean algo más aparentes ó tengan más fuerza por hablar con alguna particular experiencia que hayan hecho, al fin es certísimo que las unas y las otras cuentas que se hicieren $y$ todo lo que se numerare son cuentas de cabeza y á buen ojo, porque nadie asegurará su verdad, afirmando que él ha empadronando la gente que hay en Potosí, ni que sabe de cierto el número della, que unos afirman que hay ochenta mil indios arriba en aquella villa, y otros más o menos. $\mathrm{Y}$ pues no hay quien pueda hablar con esta certeza y seguridad de su verdad, sálgase de una vez de esta duda, averiguándolo V.E., y satisfaga ớ esta exclamación de la gente pía y experimentada que dicen no haber otro medio sino éste para perpetuidad del cero; pues sì ello pudiese tener efecto el poblar y avecindar de gente sus minas, no hay quien dude ser lo más acertado, y por lo menos sabemos que era éste el gobierno del Inca, con que esta tierra estaba ton poblada y poderosa de gente en su tiempo; y mientras no se empadronare de una vez la gente que hay, y se supiere si se puede hacer ó nó, se han de quedar en pié los juicios que tienen, por parecer ser factible, y los que tienen el contrario, $y$ siempre se ha de hablar de esto y culpar á los que pudieron tratar dello, y debían quererlo y mandarlo así S.M., como agora lo manda V.E., y no lo hicieron; principalmente que en averiguar la gente que hay en Potosí, que es el fundamento y cimiento de todo lo que se va tratando, no ha de costar mucho, pues todo se reduciría á dor dos instrucciones buenas á quien lo haga, y hacer elección de dos personas cristianas y solícitas que se ocupen en esta averiguación.

Dicen los que imposibilitan este medio que dado que haya la gente que se desea de asiento en Potosí, para el efecto dicho, que con todo esto tienen por imposible poblar con ellas las mitas ordinarias de tres á tres años de trabajo á cada indio, como está dicho. Fúndanse en que no tenían qué comer, porque les taliarían de cuarenta á cincuenta mil pacos y carneros de la tierra, que entran cada año en Potosí con la mita que viene de fuera, que viene prevenida con traer su comida.

Faltarían también de noventa á cien mil cargas de maiz y comida que mete también la misma mita, pues cuando no entre cada indio sino con siste cargas, son cerca de noventa mil, y toda esta falta sería una gran mella, que sin ella era imposible poderse sustentar.

A esto se responde que no se puede negar sino que ésta es la mayor dificultad que el caso tiene; pero mirada con algún espacio y consideración, Y tratando de medios para su remedio, no stería imposible el dárselo.

Lo que toca á la comida de carneros es lo más fácil, por estar la villa de Potosí el día de hoy lo más abundante de este género que se puede pensar. Han sido muy grandes las estancias de ganado vacuno que hay en to- 
do eso de Tomina (1) y camino de Tucumán, multiplicando fructuosamente este ganado, de suerte que hay estancias, donde de una matanza se matan mil reses, y se hace de todas ellas charqui (2), muy regalado y tan bien curado y sazonado, que se puede comer sin asarlo, y de esto se hace arrobas y se vende cada una á los indios en tres pataconles, que es cosa muy barata y cada día ha de ir baratando más, por ser grande la suma que todos los años se saca de este ganado mayor de Tucumán, y hay muchos mercaderes que andan en este trato.

De cierto que no es moralmente posible que falte el sustento de carne, conforme á lo que tengo dicho. Añadiendo ó esto, que si se poblasen pueblos, tendrían los indios sus ganados de pacos y cameros de la tierra, socorriéndoles con parte de ellos las comunidades, pues en tal caso siría justo partiesen con ellos, y es cierto que hay temples y pastos donde poderse crior $Y$ tener.

Lo que tilene más dificultad es la comida de maíz, chuño, papas, etc.; á esto se responde que no se había de tratar de estas poblaciones, sin dar tierras á los indios en que sembrasen, siendo de justicia debido el dórsela, pues se desterraban de las suyas, quitándoles la esperanza de volver á gozarlas; y medio único para quitarlos y sosegarlos, el dárselas, y era necesario, para que pudiesen sembrar y tener comida para su sustento. $Y$ si se pregunta qué tierras, á esto respondo que no es justo que tope negocio tan grave en esta dificultad, $Y$ pare $y$ se deje de hacer por ella, aunque se comprasen de españoles, volviéndoles lo que dieron á S.M. de composición (3); Y en esto no se les hacía agravio, pues para el buen gobiemo de un reino se puede tomar a un particular, ounque diga que no lo quiere vender, un género de mercadería que tenga, y se le puede $y$ debre sacar en un precio moderado; luego, para un bien tan grandioso y tan universal de todos los reinos de la cristiandad que dependen de la conservación de Potosí, bien podía S.M. quitar las tierras que tiene dadas y compuestas con los españoles, volviencio á cada uno lo que dió por ellas y pagóndoles sus mejoras; fuera de que en los Charcas hay admirables valles y en todo aquello de Macha, Moro, Caracara, y por el distrito de los Charcas, particularmente, una gran suma de tierras, que se pleitean agora entre los indios de Macha y el cabilao de los Charcas, en cuienes repartieron estas tierras cuando se compusieron; y es común voz que están agraviados en esto los indios, y si se les restituyesen estas tierras, habría en ellas para los que las pretendien y para otros muchos.

Item, hay muchas tierras en lo de Puna y Chaqui (4) y por aquella comarca, y por lo menos se deben buscar y tratar dello, y no dejarse, porque uno diga que no las hay, que cuando se busquen y no se hallen, se daría otro medio que diré luego, porque quiero satisfacer primero a lo que algunos dirán, que si se quitasen las tierras a los españoles no se añade más comida en Potosí, pues ellos las habían de sembrar con más cuidado y comodidad.

A esto se responde que no se les añade comida, sino quítoseles á los españoles la granjería de venderla á los indios y dáseles á los indios, con que los tendrán contentos y pueden vivir. Y digo más, que sí se añade comi-

(1) Provincia del Alto Perú al Esto de Chuquisaca.

(2) Came seca al sol, muy usada en todo el bajo y Alto Perú.

(3) Medie que tomó la Corona para asegurar la propiedad de tierras cuyos dueños los tenían sin justo título.

(4) Puna y Chaqui, pueblos de las Provincias vecinas a Potosí y Porco. 
da, porque los indios sembrarán sus semillas y no dejarán palmo por sembrar, y los españoles tienen muchas tierras descansadas y ocupadas con huertas, casas, recreaciones y sementeras de trigo que cogen mucha tierra.

El medio que dije daría, cuando esto faltase, es que se hiciese una athóndiga (1) en Potosí, como las hay en Sevilla y ciudades populosas de España, y son necesarias donde hay falta de comida. Esta alhóndiga se podría poner de las Provincias de Omasuyo, Pacajes, Chucuito y Paria de todos los tributos que pagan á S.M., no arrendándolos de aquí adelante, sino cobrándolos en especie, y se pagarían mejor, con más la quietud que tendrían los indios con no haberles de sacar para minas, y por mano de los contegidiores se había de fletar para Potosí toda la comida y ropa que se paga al Rey Nuestro Señor, en las partes dichas, y había de entrar en una alhóndiga, en la cual se pusiese y repartiese por su cuenta y razón, y se podría dar en un precio moderado, de suerte que S.M. no llevase en esto ni hubiese más ganancia que asegurar su Real hacienda en la cantidad que habían de hallorse estos géneros en las Provincias, donde se habían de vender por pregones y remates, y juntamente socorrer á los indios en darles comidas y vestidos á baratos y moderados precios, que lo seríon sin duda donde no se buscase más granjería que la dicha.

Y si se dijese que con qué han de comprar los indios esta comida y vestido, aunque se les dé tan barato, que agora no la compran, sino cadía uno la lleva de su cosecha y tierra, á esto se responde: que no habiendo de caminar $\mathrm{y}$ peregrinar los indios cuatro meses del año, trabajarían voluntariamenIe en Potosí y ganarían mucha plata, y para muchos sería todo el año, en diferentes ministerios, de trabajo, y ganarían mucho con que gastar y pagar y comprar lo que tuviesen necesidad, y se beneficiarían más minas.

Y traigo a la memoria de S.E. un papel que, de cinco años á esta parte, dió á S.E. un soldado llamado... (2), donde daba una traza fácil $y$ muy útil para esta manera de alhóndiga, para que se trabaje menos en pensar la disposición que ha de tener, y de donde se ha de proveer, y por qué manos, etc. etc.

Esto es lo que hablan todos y dificulton en esta materia. Mi sentir en ello sería, que habiendo oído V.E. en ello sus pareceres, tomados por escripto, los remitiese á la Audilencia de los Charcas, para que allá se tratase con personas prácticas y expertas de la tierra, y se confiriese todo y viese la que se puede facilitar y menos dificultar, advirtiendo que en lel pedir parecer $y$ en el oir se vaya con recato con personas hacendadas y que tienen raíces, que éstas han de mirar su bien particular y ordenar á el sus razones y no se ha de acertar, y cuando se haya trabajado en buscarla, podrá V.E. con lo que resultare, tomar la última resolución y se habrá cumplido con la cédula de S.M. Y satisfecho á los que hablan en esta materia y desiean esto, Y cumplido en lo que se debe con la conciencia; y por lo menos se podrán agora remediar muchas injusticias y abusos presentes que piden remedio y se les pueden dar, $y$ por consiguiente, se les debe. Irélos tocando brevemente.

(1) Mercado de cereales.

(2) En blanco en el original. 


\section{Cosas dignas de remedio en Potosí.}

Que no paguen al Rey más tasa los indios que vienen á la mita que los que se quedan en la provincia, pues es tan excesivo su trabajo, que dan en él las vidas, y dél y de su servicio resulta tan gron utilidad á la hacienda Real, como el que goza de quintos y que sus reinos tengan abundancia de plata, y no es justo que porque sirven de esta manera paguen más. Y por no alargarme ien este punto, digo que no hallo fundamento por donde $S$. M. deba llevar semejante tributo. Y si hasta aquí se ha dicho que estaba entablado en esta forma y que no tenían mano los Señores Virreyes para desatar esta obligación, ahora las dá S.M. y lo manda; hágase por armor del Señor, que según los daños se sabe que los indios padecen y reciben en sacarlos de sus casas y llevarlos á las minas, no sólo se les había de relajar el tributo, sino que de todo punto se les había de hacer libres y franoos de pagarle, y quizós con esto habría para la mita más indios é irían á ellas con más gusto y trabajarían más y darían por este camino más suave y mayor riqueza.

Que se les pague a todos los indios el tiempo que gaston en el camino, cuando van a trabajar, tasándoles los días que fuese justo, y que esto se entienda con todas las mitas, así con las que van a Potosí, como á cualquier otro asiento de minas, y las que se dan para sementeras y otro cualquier repartimiento, al cual concurran los indios viniendo algunas leguas. Y esto estớ pujesto en justicia, que desde el día que el indio sale de su casa, sale en servicio de los mineros ó chacareros, á quien va á servir; luego es justicia que se le pague el tal servicio. Un oídor y un corregidor, desde el día en que se embarcan en Sanlúcar, les corre su salario, hasta que llegue á su plaza. Una casa que se arrienda, aunque está vacía, se paga. A una mula que se alquila, le pagan la ida y la vuelta, y lo mismo al mozo que la lle$\mathrm{va}$, aunque halle quien se la alquile á su vuelta y no vuelva vacío. Luego está puesto en justicia que donde hay la misma razón y corre mayor, se guarde la propia igualdad y recompensa.

Diicen á esto los mineros de Potosí que el señor Marqués de Cañete subió un cuartillo en el jornal de cada día, por la ida y vuelta, y que así se dan ahora 4 reales, no dándose antes sino tres reales y tres cuartillos. A esto se responde que los cuatro reales que les dan cada día, los merecen muY bien por el trabajo de aquel día, y que no está con ellos bien recompensado, y que así, no lo debe estar la ida y la vuelta, sino se les hace otra mayor satisfacción. La dificultad que esto tiene, es cómo se le puede pagar á cada uno in justitiam commutativom, que al que viene de más lejos se le paguen más días de camino, y al que menos, menos, porque si todos sirvieran a un año, fuera fácil, y repartiéndose entre tantos, es imposible, y mudándose los indios cada mes, mucho más imposible. $\mathrm{Y}$ al fin, digo que es así y que no hay otra traza sino subirles igualmente ó todos el jornal de cada día, satisfaciéndoles por esta vía. Dicen á esto los minzros que serían perderse ellos si se les subiese el jornal, por estar las minas muy flacas, los gastos de Potosí muy grandes, y finalmente, sería este medio para acabarse todo, porque ellos alzarían mano de la labor por no rematarse y perderse.

A esto se responde y concluye fácilmente. Lo $1^{\circ}-$ Con decir que á los indios que mingan (1) dan tres tanto que á los indios de cédula y de obliga-

(1) Mingar es trabajar a jornal ó alquilar sus servicios por cierta suma. 
ción, lo cual no hicieran si no tuvieran ganancia. $2^{\circ}-\mathrm{El}$ que da por 200 indios 200 pesos de arrendamiento; seguro tiene el no perderse, pues los da.

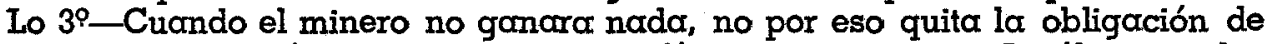
pagar al indio; búsquese camino y satisfágase esta justicia. Lo último, si los metales están el día de hoy más bajos, también lo están todos los gastos del cerro y cosas que se requieren para el beneficio dél. Un español lleva la mitad del salorio menos; un quintal de azogue vale un tercio menos; el trajin de los metales es á dos tercios menos; al minero, la comida menos, el vestido vale menos; luego si el minero goza de tantos baratos, justo es que cumpla su obligación y pague al indio lo que justamente mereciere. En cuónto será bien darle, véase por lo que queda dicho de los diez meses en que se ocupan los indios, cuatro en ir y volver á sus casas, y seis en trabajar, y lo que por todo dijimos que se les daba y venía á gozar el indio en limpio, y también se puede juzgar conforme ó lo que gastan en vestir y comer en el dicho tiempo, que es lo menos que se le debe dar ó cada uno por su trabajo, y lo que es tan preciosísimamente obligatorio, que cuando se lo negase un amo á su esclavo podría lícitamente hurtárselo; advirtiendo que el juicio de lo que se hubiere de añadir, no se ha de hacer, para no errar, sino con parecer de religioso, siervos de Dios y personas seglares, no interesadas $y$ de buen celo.

Alegaron ó este propósito los mineros que los indios les hurtan metales, y que con esto les satisfacen. Esta razón no tiene fundamento para excusarse por ella, y así no me alargo en la respuesta.

Para que se haga esta satisfacción tan debida más suavemente y con menos daño de los mineros, conviene poner todo rigor en que no haya arrendamientos de minas ni ingenios por ninguna razón, principalmente cuando las minas é ingenios no tienen sustancia; $y$ el arrendamiento no se hace sino por sólo los indios, que con estos arrendamientos se empobrecen los mineros que los hacen, con la mucha plata que pagan, y reciben mil injusti cias los indios, y tienen los que los arriendan obligación de restitución por lo que en esta forma llevan. Parece que esto ha deseado y desea V.E.; así es verdad; pero véanse de nuevo los medios que habrá para cerrar del todo esta puerta, como pemiciosa en gran manera. Declárese en el repartimiento que S.E. hiciere, que de tal monera se dan aquellos indios para que ninguno trabaje, que no los pueda arrendar, y que para el tal arrendamiento no adquiera derecho. Y mándese que el Corregidor y Alcaldes de minas visiten cada semana el cerro, y véase si se trae labor en todas las minas para las cuales se han dado indios; y en sabiendo que no, quítensele luego los indios, y sea ipso facto del minero que los arrendaba, y no de otro, que pues él daba 100 rs. por cada uno, la mejor prueba que puede dar de que los había menester para sus minas; y con esto temerón todos de arrendar sus indios, viendo que han de ser parra la persona á quien los arriendan.

Mándese también tomar juramento ó los señores de minas é ingenios, que no han de arrendar sus indios con sus haciendas ó sin ellas, sin licencior del Virrey, y fortalézcase por todos los caminos y vías negocio de tanta importancia.

No dé V.E. á nadie licencia para arrendar sus haciendas, que no conste manifiestamente que son muy buenas y de tanto interés que no se arrienda sólo el de los indios que tienen; y mande V.E. el día de hoy examinar Ias licencias que tiene dadas para estos arrendamientos, y verá cómo los más no tienen otra justicia sino el pobre trabajo de los indios; porque las minas que con ellos se arrendaron no se labran, ni los ingenios; y ó estos tales quítenseles las licencias y mándeseles que beneficien sus haciendas 6 
que dejen los indios. Y con esto se conseguirá una de dos cosas; 6 que serán mós minas las que se labraren, ó se darán los indios á los que los merecen $Y$ no se venderón, y andarán más descansados los mineros quitóndoseles estos subsidias y pagas gruesas que hacen por compras de indios, que no son otra cosa estos arrendamientos, $y$ cuando empobrecieren veinte ó treinta personas por esto, sería menos mál que permitir tantos males, y haríales bien á sus almas, pues no están seguros ellos y sus haciendas en egtos arrendamientos, y S.M. manda en esta cédula que se quiten.

4.-Padecen otro grande agravio los indios por manos de sus caciques, que es alquilar 50 y 100 indios á los mineros, y estos indios son los que absolutamente trabajan mós en el cerro, sin piedad del minero, porque quiere sacar de su trabajo su plata, y sin que el indio pueda quejarse, porque conio es su cacique el que lo tiene alquilado, teme ir á la justicia con los agratios que le hacen, porque no le descuartice el cacique, y así es yunque donde se da y martilla sin que pueda abrir la boca, ni decir "oquí me duele". Téngase particular vigilancia en esto y en quitar todo poder y facultad á los caciques y capitanes para esto, y saviendo que lo hacen, castigarlos con treinta días de cớrcel á la primera vez, y con destierro á la segunda, de suerte que no se atreverán más á hacerlo y mándelo así S.E.

$5^{\circ}$ - Ágravio es que los capitanes, caciques, curacas y hilacatas (1), que estón en Potosí para hacer cumplir las mitas de los indios suyos, no pudiendo enterar el número, porque no vienen otros de su tierra con que poder suplir, hacen que vuelvan a servir los indios que habíar ya cumplido con su mita, entreteniéndolos y haciéndolos cumplir y suplir contra justicia, lo que por justicia les hacen cumplir. El remedio que esto tiene es mandar apretadísimumente la ejecución de lo que tiene V.E. ya mandado, que cumpliendo una mita salga de Potosí con sus capitanes señalados, para que la lleven y vuelvan ć sus provincias, y que haya mucho rigor en el cumplimiento debido de éste.

6:- Sucede á algunos caciques que, por estar despobladas sus Provincias, no tiensn con qué enterar la mita en Potosí, y les fuerzan las justicias y señores de las minas á que alquilen los que les faltan á su costa y don... (2), á cada indio que alquilan cada semana; de suerte que si á un cacique le faltan en una semana 20 indios, le cuestan 180 pesos, y si esto le dura un mes, gasta 720; y para esto vende sus mulas, carneros, vestidos, plata labrada, y lo que puede y no puede. Pues es certísimo que vino un cacique el año 60l á la celda de un Padre de la Compañía, y llorando con grande sentimiento, le dijo: Padre, yo estoy obligado á entregar 31 indios, y destos há seis meses que me falton 16, y cada semana los he enterado y pagado 126 pesos en alquilarlos, y para esto he vendido una mula que tenía, mis carneros $\mathrm{y}$ mis vestidos que tenía, $\mathrm{y}$ he buscado plata prestada, echando derrama (3) entre mis indios; y no teniendo remedio para entregar los indios, la semana pasada empeñé una hija que tengo, á un español, porque me prestase 64 pesos que me faltaban, y la semana que viene, no sé que hacerme, sino ahorcarme".

Esta es una injusticia clara, y el remedio también lo es mandar que, constando que el cacique no tiene los indios para entregar su mita ó por habérsele huido, enfermado, etc., ó por no haberlos en sus pueblos, no se le pi-

(1) Nombre que en la lengua aymara significa mayoral, cabeza de familia ó de grupo.

(2) En blanco en el original. Debe decir nueve pesos.

(3) Contribución ó cupo. 
dan; y no se le admitan indios de otra parcialidad, que sin duda serón alquilados, sino de la suya. Y cuando se dudase que es malicia del indio, póngasele en la córcel y castíguesele con esto, y no con una pena tan rigorosa. como es obligarle á lo imposible y á redimirse por los escalones y grados que queda dicho en el caso referido.

$7^{\circ}$-Agravian también á los indios los mayordomos que están en las minas, en no dejarlos bajar del cerro los domingos á descansar á sus casas, porque el lunes empiecen temprano á trabajar, dóndoles tarea que cumplan: cada día, y conforme á ella se les paga su trabajo, v. gr., seis costalillos cada día, $y$ al fin de la semana al que ha sacado treinta se le paga el jornal de cinco días, y no de seis. Es justo se remedie esto con gran vigilancia, pues aún manda S.M. en su Real cédula que les tasen y moderen á los indios las horas de su trabajo.

$Y$ no se contentan los mayordomos con hacer trabajar doce horas al indio, sino que en ellas ha de cumplir su tarea el flaco igualmente con el que tiene fuerzas, y no se le paga conforme al tiempo y días, sino respecto. de la medida que le tienen señalada que sqque. Y esta se remediará echando un pregón cada principio de mes que se reparte la. mita, en que se les diga á los indios en su lengua que no han de trabajar por tareas sino, por lo que pudiere cada uno; $y$ si les pidieren tareas, el minero ó mayordomo se venga á quejar al Corregidor, á cuyo cargo y obligación será luego echar el tal mayordomo en la cárcel y tenerla allí diez días por la primera vez, y por la segunda desterrarle del cerro, y lo mismo se les diga á los indios que se quejen, cuando les detuvieren las fiestas, y el Cornegidor castigue al modo dicho al que lo hiciere. Dirán algunos que el modo más suave para los indios es darles su tarea, que cuando no la tienen, anda el mayordomo tras. ellos acocé́ndolos y azotándolos porque se den prisa y, al fin, trae cada miserable junto $\alpha$ si dos que le martirizan: el trabajo de la mina y el que le dá el mayordomo en aguijarle y espantarle. A esto se responde que se les diga á los indios que se vengan á quejar en haciéndoles mal tratamiento, $y$ el Corregidor castigue sin remisión á quien lo hiciere, y cada uno mirará por sí, pues correrá con su pena cualquier desmán que hiciere.

$8^{\circ}$-Es que como los caciques no pueden entregar el número de los in. dios que cada año están obligados, el Corregidor de Potosí despacha jueces: españoles para que hagan á les caciques que enteren, y estos jueces van con días y salarios; $y$ como los indios se ven imposibilitados, á los que les quieren obligar, redimen su obligación con pagar al juez sus salarios, y no se entera la mita, y el cacique quiere cobrar de sus indios lo que pagó al juez, y echa derrama y cobra de la viuda, vendiéndole sus carnerillos, y de la huértana, empeñándole sus vistidillos, y de esta manera abissus abissum invocat, una justicia llama ó otra, y todo ello hace una labor de injusticias.

El remedio es cumplir lo que S.M. manda, que no se cobren estos salarios de los indios, sino de los mineros, y es muy puesto en razón. Y porque sulelen ser las más veces culpas de los corregidores, condénenle en los salarios y dése aviso a V.S., para que los castigue; y si fueren los caciques, no se les dé pena pecuniaria, sino cárcel o suspensión de oficio; que así lo mandor S.M.; en este caso paguen los mineros los salorios.

En las minas de las Salinas tienen un extraño modo, de cobrar estos salcrios, que ofende sólo el oírlo, y es que cada indio que falta, paga al juez 12 pesos porque lleva tres días de comisión, cada uno á cuatro pesos ensayados. Esto es digno de remedio.

9:-El trabajo que pasan los indios en las minas es grandísimo, por el mal reparto que tienen, y porque cuando dan en agua, les hacen trabajor 
metidos en ella, y porque las escaleras no tienen sus barbacoas á sus trechos, que son los que llamamos descansos; que es cosa rigorosa que suba un indajo veinte estados, trabado á una guasca y asido de ella, y que no tenga los descansos muy ordinarios para tomar aliento, y para que si unos suben y olros bajan, se puedan opartar y dar lugar los unos á los otros. Todo esto nace de que no hay veedores, como conviene, ni alcaldes de minas, que para estiss oficios no pide que sean caballeros ni sólo buenos cristianos, sino hombr əs sueltos, trabajadores y que entiendan el cerro y anden como culiebras todo el día. El remedio que esto tiene es persuadirse V.E. lo mucho que inıporta no proveer estos oficios sino á personas tales y que se busquen para ello. Y sería bien que el Corregidor y Presidente de los Charcas propusiesen á V.E., cuando vacase algún oficio de éstos, tres personas, las más hábiles para ello, y que V.E. nombrase la que fuese servido, y que si ésta hiciese bien el oficio, no sé le quitase, y si procediese mal y no acudiese á su obligación, avisase el Corregidor á V.E. para que le removiese.

Item, convendría poner más veedores, pues la disposición del cerro lo pide, y éstos que se añadiesen, fuesen hombres de menos calidad y más trabajo, ó quien se les diese 500 pesos de salario, que serían muy bien empleados 1,000 ó 2,000 pesos en cuatro veedores de éstos, y el que lo es ahora, que fuese como el más principal y se fuesen haciendo los veedores menores, para merecer cada uno serlo mayor, conforme su buena cuenta $\mathrm{y}$ diligencia, y con esto se onimarían muy bien á hacer sus oficios.

$10^{\circ}-$ Manda S.M., en su Real cédula, que se procure dar en los asientos de minas la comida más barata a los indios; sería de gran bien y beneficio que recibirían, y fácil en la forma dicha de poner alhóndigas, etc.

$11^{\circ}-$ Hay un descuido grande en permitir las borracheras á estos in. dios, públicas en las calles y plazas, y como cosa en que no creo que se reparc, pues no se remedia.

En Potosí, estando yo un día de fiesta, por las calles forzosas que pasan para ir al colegio, ántes de anochecer, vi tres borracheras públicas, dos en dos corrales ${ }_{2}$ y otra en la misma calle, con sus danzas y atambor y mates de chicha en las manos, que cuando estaban los indios en sus idolatrías no podían ocuparse en este ejercicio con mós seguridad y devoción. Mande V.E. á todos los alguaciles que les derramen la chicha, y á cualquier alguacil que los viere, y á los caciques que lo permitieren, den seis días de cárcel por la primera vez, y por la segunda doce, y castígueseles de esta manera, de suerte que tenga remedio vicio tan pernicioso y ton nocivo para sus almas y cuerpos.

Esto es en general y particular lo que acerca de minas se me ofrece; con que está respondido y dicho cuanto á la ejecución de la cédula Recil es mi sentir, y lo que juzgo se debe hacer para en ella cumplir con el intento de la otra cosa que manda S.M., que es el quitar los servicios personales á los encomenderos; es cosa justísima, y que, como tan clara, no me alargo en apoyarla.

Concluyo con decir que si la Real cédula de S.M. se pudiera ejecutar, sería el mayor remedio y mós propia encuadernación que se podrá dar á este reino. $Y$ supuesto que no se puede por los inconvenientes dichos, es justo y debido retornar a informar á las cosas de esta tierra con una nueva vida, cual la pide el estado presente, y esto por todos los caminos, modos y maneras que se pueden, tomando, para acertar, los pareceres de personas do experiencia y buena conciencia que haya en esta ciudad, escribiendo V.E. á los corregidores de indios, mandando que se junten con cuatro ó seis clérigos ó religiosos de los doctrinantes de su corregimiento, y los de españoles 
con los prelados de las religiones de su ciudad y con tres ó cuatro caballeros cristionos que V.E. les puede señalor, que traten en esta junta de los daños que reciben los indios en toda género de servicios y ministerios en que los ocupan en su distrito, qué remedios tienen, con qué facilidad y dificultad se pueden alentar, y que envíen sus pareceres y firmas ó V.E., que entendiendo mejor por esta vía el estado del reino, tendrá V.E. obligación á remediar lo que fuere capaz de remedio, y avisar á S.M. de lo que no lo tiene, y por qué causas; considerando V.E. que esta maieria de agravio de indios es en la que todos tienen pecho y cristiandad, viendo lo que padeann. Y cuando hasta aquí se vá tratando de remedio, se responde que no había mano ni facultad para ello; S.M., informado de este miserable estado, y peligroso en conciencia para los que lo toleran, se la dá a V.E. muy amplia en todo. Nadie puede usar de ella con más bien de este reino que V.E., por su gran cristiandad y celo de la honra de Dios y de su Rey; que honra de nuestro Rey es que sus vasallos sean bien tratados y desagraviados, y más cuya conservación tanto le importa; V.E. tiene la noticia y la comprensión de las cosas de este reino que se puede desear; déjeles V.E. este beneficio hecho á los naturales dél, y ampare y defienda gente tan indefensa, y disponga V.E. este servicio personal, de suerte que no se deje de hacer nada en su favor de lo que se pudiere; que lo que saliere de esta coyuntura y punto será para no esperarle bueno jamás, y S.M. será muy servido con lo que V.E. hiciere, y este reino le quedará en perpetua obligación de memoria y reconocimiento por tan gran bisn.

Este memorial dí al Señor D. Luis de Velasco, Virrey de estos reinos, y S.E. acudió con gran celo y cristiandad al remedio de muchas de las cosas que se notan en él, que lo pedían.--ALONSO MESSIA.

Para el Señor D. Rodrigo de Aguiar y Acuña, del Consejo del Rey, Nuestro Señor, y su oidor en el de Indias. 


\section{Pareceres de los Padres de la Compañía de Iesús de Potosí. 1610}

Para pedir este parecer mandó el Señor Presidente y el Señor Oídor que en 8 de Marzo de 610 se juntasen en la casa del dicho Señor Presidente el Señor Corregidor Don Rafuel Ortiz de Sotomayor y los Señores Oficiales Reales y los perlados de las Religiones y algunos letrados y otros cavalleros $\mathrm{y}$ azogueros y mineros deste pueblo $\mathrm{y}$ abiéndoseles a todos juntos dado $a$ entender lo que el Señor Virrey, en nombre de Su Magestad, pedía y pretendía que es la resolución y parecer de las dudas arriba propuestas, se determinó que por ser el negocio tan grave se repartiesen por lás Religiones y en cada una dellas los que estaban allí presentes y otros con el Señor Presidente $y$ on cada parte destas se hiciese un parecer, de suerte que fuesen 5 ó 6 y todos se pusiesen por escrito para otra junta general y allí se confiriesen $y$ limasen $y$ ansi se embiasen al Señor Virrey los que mejor pareciesen $y$ con ellos determinase alló Su Excelencia lo que fuese servido.

Y el parecer que se dá del Colegio de la Compañía de Jesús desta villa y de los cavalleros y azogueros que allí se juntaron es el siguiente. Pero por ser esta cosa grabísima, ansi para el descargo de las conciencias de Su Magestad y de sus criados y executores deste serbicio personal y de los mineros y azogueros desta villa de Potosí, como para el bien de los indios y librallos de las injusticias y agrabios que hoy padecen y para que mejor se entienda el caso, el parecer y el remedio que en el se dá y propone será menester yr en su resolución con distinción de capítulos y números.

Capítulo 1 - De algunos notables fundamentos que es menester presuponer al principio desta materia los quales se pordrón brevemente para su mayor inteligencia y claridad.

Lo primero, se presupone que el fin y blanco principal desta tan grave consultu es quietar conciencias, quitor pecados y escrúpulos y evitar injusticias y agrabios contra el próximo y el parecer que se diese ha de yr enderezado $a$ este fin y blanco, quia hic esi eis tructus ut oruferatur peccatum. como dice Isaías y asi el parecer que fuese más encaminado a quitar escrúpulos Y quietar las conciencias de Su Magestad y del Señor Virrey y de los demás ministros que atienden a la eqecución deste serbicio personal y a librar más a los yndios de las vejaciones y molestias que oy padecen (no obstante que tubiese algunas dificultades temporales o algunos mayores gastosi ese será mejor y más acertado, quía primo loco qucerendum est regr.um Dei, como dijo Christo Nuestro Señor y en otra parte: quid prodest (1), de lo que se sigue

(1) Homini si mundum universum lucrefur, animse vero suae detrimentum patiatur. 
que atravesóndose un pecado mortal y aun un venial o escrúpulo grave de conciencia de una parte y de la otra quantos trabajos corporales y bienes temporales ay o puede aver en el mundo, deven el Rey y sus ministros incurrir y meterse en todos los trabajos corporales y querer que se pierdan todos los bienes temporales a trueco de que con sus leyes, mandatos, modo de gobierno y execución del no se cometa un pecado mortal ó se incurra en algún escrúpulo grave de injusticia y agrabio contra el próximo e indio y este presupuesto $\in \mathrm{s}$ muY necesario para lo que adelante se dirá.

Lo segundo, se presupone que aquí no se trata ni se pide yarecer sobre si se echarán los yndios a las minas de Potosí, porque este parecer le tomó el Señor Francisco de Toledo y sobre lo que en él dijeron algunos barones graves, santos y letrados, se retractaron a la hora de la muerte y en otros tiempos, por averles parecido cosa muy escrupulosa que a hombres libres, ynocentes, contra su voluntad y, en la execuciónón, con tantas injusticias y agrabios se ubiese forzado a venir a las minas de Potosír ni tampoco se trata de aumentar esta mita ni de que vengan más indics, como se trató en unas consultas que ubo en Lima, en tiempo del Señor Don Luis de Velasco, a las quales respondieron todos los teólogos y letrados que se hallaron en ellas (y rnuy bien) que no se podía hacer en conciencia el añadir más número de indios a nuebos minerales y que ansi no se tratase dello jamás; pero aquí no se trata sino de que los que bỉenen a la mita de Potosí sean más relevados y sirvan a este cerro, (supuesto que el Rey quiere que sirban) con menos injusticias de parte del Rey y de sus ministros y con menos agrabios de parte de los mineros y con menos vejaciones que se les hagan a los indios y quizá se podría hallar traza y manera con que en algún modo se justificase más la injusticia que por ventura entonces se les hizo y con que cesasen muchos de los escrúpulos de si se les bá continuando el día de oy, que sería ien parte gran remedio de la seguridad de la conciencia Real y de sus ministros, como lo diremos abajo en el $N^{9} 23$, que esto es lo que pretendemos en este parecer.

Lo tercero, se presupone que agora se tome este modo ú el otro de asentar las cosas de Potosí (que oy están ton desenquadernadas y escrupulosas como todos savemos) qualquiera que se elixa ha de tener muchos yncombi nientes y dificultades, porque solo Dios alcanza el governar sin ellos y la providencia humana no puede llegar a este punto. Adonde ella alconza es a que se pesen los yncombinientes que ory de la una parte y de la otra y a poder escojer los menores que en eso está ser el gobierno prudente y acertado, como dice San Augustin, y lo confirma la experiencia y aun el Spíritu Santo añade en el Cap. 33 del Eclesiástico lo mesmo de las razones y congruencias que se pueden traer para qualquiera cosa que todas parece que tienen sus soluciones y réplicas: sunt duo contra duo et unum contra unum, para que se eche de ver que las razones que trajéremos para confirmar nuestro pareqer tendrán algunas soluciones y las que se trajeren por la parte contraria también tendrán las suyas y la prudencia (que como dice Santo Thomas ( ${ }^{q}$ 2 ae. q. 47 Art. $5^{\circ}$ y $6^{\circ}$ ). consiste en tres cosas, en consultar bien, en juzgar bien y en executar bien) habrá aquí de exerritar sus actos. el consultar bien \$o ha echo, en aver comunicado este negocio con personas tan doctas, graves $\mathrm{y}$ experimentadas y que han dificultado tanto el caso y traído por ámbas partes tantas y tan eficaces razones; pero agora queda a los ministros de Su Magestad y al Señor Virrey juzgar bien, como después les quedará el tercer acto de la prudencia que es executar bien la que se eligiere. Pero para el segundo acto del juzgar bien se advierte lo que diaen los Theólogos sobre 
Santo Tomás (19 2 ae. q. 19 Art. 6), que no es la más probable opinión aquella que tiene muchos autores o letrados por sí, sino la que tiene más fuertes y mejores razones, cunque aconteciese no tener más de muy pocos cutores que la siguiesen o por ser nueba, muy sutil y delicada la razón y no averse los demás fundado en ella. todas estos notables y presupuesto son muy necesarios para la resolución acertada del caso y para lo que en el se deve decidir y escoger.

\section{Capítulo 2:-De los grandes y excesibos agravios que los yndios reciben en venir a la mita do Potosí como agora bienen.}

El primero agravio, que es el esencial y sustancial y como alma del cuerpo de los demás, es hazer benir $\alpha$ unos hombres, libres, ynocentes y sin culpa, forzados, contra su voluntad y quitándoles la libertad que Dios les dió, a un travajo tan grande y excesivo como la lavor destas minas de Potosí, que estón a 150 y a 200 estados devajo de tierra y este es un punto tan escrupuloso que muchos perlados eclesiósticos de religiones y hombres doctos y letrados de los que lo aconsejaron a D. Francisco de Toledo se retractaron y desdijeron después, diziendo que no avian sabido lo que avían aconsejado ni el parecer que avían dado le habían entendido bien y los que después an venido, theólogos, predicadores, letrados, confesores y hombres doctos, nunca an querido meterse en aprovarlo ni dar claramente en esto su parecer, ansi porque el Rey no se lo pide como porque si ellos le diessen, ven que avía de ser sin fructo ni provecho, sino quizá con escóndalo Y rebolución del Reyno y ministros del Rey, ni cun Su Magestad del Rey Don Felipe II (que esté en el cielo) no se save que aya imbiado jamás aprobación expresa de lo que hizo Don Francisco de Toledo en el modo de entablar esta mita, sino que agora se continúa por una permisión tácita y unas Cédulas que indirectamente mandan que se cumplan las Ordenes de Don Francisco de Toledo. Y los lotrados de España dizen que en lo que toca a esto los theólogos y letrados del Perú que tenían la cosa presente lo devieron de mirar bien y nunca se acaba de salir destos escrúpulos y si agora se dize que biene una Cédula dia $\mathrm{Su}$ Magestad en que manda que los yndios sirban en minas ni la emos vista ni savemos qué calidad y condiciones y escrúpulos trae. El segundo agravio que sə les haze, cjejado el de la libertad de que acavamos de dezir, es hazerles dexar sus casas, chácaras, estancias, crías de ganado, sementeras y al mejor tiempo dezirles a los yndios en sus pueblos: alto, que os cave la mita de Potosí, lo que sienten algunos yndios tanto que de buena gana, por redimir aquella vejación tan grande y no perder del todo sus haziendas, dan 300 , 400 y aun 500 pesos $\alpha$ otro indio para que venga en su lugar, por lo qual se echa de ver el sentimiento que tienen en venir y las incomodidades que en esto padecen $y$ lo que les importa el quedarse $y$, los que no tienen tanto caudal con que poder rescatar esta vejación y les es forzoso el salir, salen perdiendo todo le que arriva se dijo y más y es cosa lastimosa el verles despedir, al punto de la venida, de sus padres, ó a los maridos de sus mujeres y hijos (quando por algún caso los dejan allá y ellos no pueden venir) $\alpha$ los hermanos de sus hermanas, a los yernos de sus suegras y finalmente los parientes de su parentela, llorando y gritando los unos, lamentándose los otros, que parece día de juicio; al Corregidor con azotes y con atarles las manos, que quebraría los corozones de unos turcos, quanto más los de christionos el ver este espectáculo tan lastimoso y iesto en cada pueblo y cada año muchas 
veces, en lo qual parece moralmente imposible que deje de aver muchos pecados graves.

El tercero agravio, que tras la pérdida de livertad $\mathrm{y}$ de las haziendas y cosas que tenían en su pueblo $₹$ de la compañía de hijos, padres, mujeres y parientes, entro el hazerles benir de 180 y 160 y 150 ó menos leguas, según la distancia de sus pueblos, caminando por punas y despoblados con sus hijos de las manos, aunque sean chicuelos (en lo qual tardan 3 ó 4 meses) sin ninguna paga, sino a su costa bienen gastando el matalotaje que allegaron en mucho tiempo en sus pueblos y tierras, cargados sus carneros, de chuño, papas ó maiz para el camino y matando los carneros de la tierra que traen para comer an el. Que aviendo gastado 4 meses en el camino y 4 en la labor del cerro, quando llegan acá, porque la demás del año no se lo pagan y 4 en volver a su tierra, por un año les dan 40 pesos que son los que les pagan los mineros por los 4 meses que sirvieron en el cerro $\mathrm{y}$, para ganar estos 40 pesos, largamente abrán ellos gastado y perdido de la comodidad y haziendas que tenían en sus casas y puebios más de 100 ó 200 pesos y si a esto se opone que ya está mandado pagarles esta venida, respondo que qué importa, si está apelado por los mineros deste mandato y se quedó assi y se quedará toda la vida.

El cuarto agravio, gravísimo, ies que andan siempre con un continuo y perpetuo movimiento, yendo, viniendo, tomando. De lo que se sigue el no crecer los yndios, el no multiplicar, el morirse las criaturas, porque nacen en esas punas, caminos y despoblados sin abrigo ni alvergue ninguno y al mo rírseles los chiquillos que sacaron de su tierra quando venían u de Potosí quando tornaban y el darles enfermedades $\alpha$ los padres o madres en esas punas donde no ay más abriga que dormir devajo de la capa del cielo ni más ospital y medicinas que un yermo desamparado de todo refrigerio humano, frío, lleno de vientos y torbellinos, aguas y granizos.

El quinto daño: que muchos indios que enferman en los caminos, $\alpha$ la yda o a la buelta, por ser tan largos, se mueren en esas punas ó despoblados sin confesión, sin Sacramentos ni sin los sufragios de la Iglesia y las viudas, quando van a sus pueblos o bienen a Potosí, como ay una Orden de Don Francisco de Toledo que la viuda que dijese que murió su marido traiga testimonio del cura que le enterró y que asi no le pidan la tasa, como no ay allí cura que dé el tal testimonio, no le vale con los caciques decir que se murió su marido y assi la cobran della sin réplica ni remedio por muchos años.

El sexto daño y agravio: que con este modo de yr y venir las veces que les cabe la mita a los indios no se les deja que tengan haziendas, chácaras fijas ni crianzas de ganados ni otros bienes raices ni estables, más de los que tienen en sus casas, que es cosa miserable y desventurada que aya una república y Reino de tanta gente que los moradores y abitadores del (no extranjeros sino naturales del propio Reyno) que ayan de andar siempre como gitanos con el bato $y$ ajuar a cuestas $y$ esto lo tengan trazado las leyes y el goviemo, de manera que no pueda ser de otra sino desta manera; cosa lastimosa y digna de remedio.

El séptimo daño que se sigue deste modo de yr y benir cada año 12,500 indios a la mita y servicio de Potosí es que forzosamente cada año bienen muchos indios nuebos que llamamos acó mozorunas que quiere decir hombre nuevo, que es como soldado visoño; estos quando llegan a Potosí con el horror y espanto que trajeron de la plática que avían tenido con los demás no osan subir por sus personas al cerro, en un mes o dos ó mas tiempo, según el valor de los carneros ó chuño ó maiz que trajeron, porque todo esto lo ben- 
den para dar 7 pesos y medio cada semana a otro yndio que sube y travaja por ellos y quando ya no tienen que vender ni plata con que alquilar otro, suben ellos como se hallan forzados y como son nuebos travajan con riesgo suyo y assi quando algunos se descalabran, perniquiebran o matan en las minas, son de ordinario estos mozorunas (y quando nada desto suceda, lo que es cierto es que travajan menos y hazen poco como soldados visoños ý de aquí resulta que los mineros los azotan, los aporrean y maltratan, los aiquilan y asientan por 5 días de travajo ó 3 ó 3 y medio y ellos, visto el mal tratamiento, se huyen y dexan la mita desamparada y fuerzan al indio cacique las Justicias y los mineros a que mingue otro indio en lugar del que se huyó.

El octavo daño y agravio, que es intolerable y el que parece que no se puede sufrir, es el de los mingas, que es alquilar otros indios por los ausentes que no an vienido de sus pueblos o que se an huído por el mal tratamiento ó por lo que ellos han querido, y agora 4 ó 5 oños se hizo muy exacta averiguación de quantos eran estos yndios que se mingavan cada lumes para servir por toda la semana y se halió que las mitas estavan entonces más faltas y que se mingavan 1,200 indios, que a 9 pesos cada uno como entonces se mingavan, son 10,800 pesos cada semana, que muitiplicados por 50 semanas son 540,000 pesos cada año. Esos sacavan los indios y caciques de su bolsa cada año para sustentor la minga de los ausentes y de los que par mozorunas y por no querer subir al cerro faltavan en él. Y aunque agora, por la diligencia de los Corregidores está más enterada la mita y ay menos mingas y se les a vajado el jornul por el Corragidor D. Rafael Ortiz a 7 y medio pesos cada semana, todavía se mingan de 600 a 700 indios cada semana, que bendrán a ser más de 230,000 pesos cada año y aunqué destos mingas ay muchos que mingan voluntariamente, porque les está mejor o sienten mayor ganancia en otros oficios que ellos tienen, pero con todo eso los involuntarios y ausentes son muchos, de los quales se puede tener mucho escrúpulo porque puede aver muchas causas justas por las quales no devan mingar $\alpha$ su costa y es hacerles notable ergravio el llevarles tanta hazienda sin deverla, y todo este agravio de mingas resulta del venir la mita a Potosí como agora biene y resultará siempre, aunque se reduzcan a sus pueblos, porque nunca las mitas bendrán enteras o si biniessen alguna vez no dejarán de huirse los mozorunas $u$ otros como agora se huyen.

El noveno daño notable que de venir a estas mitas como bienen agora se sigue, es la universal destrucción y despoblación del Reino y de los pueblos sujetos $\alpha$ esta mita porque para quien lo a visto no es menester decir más diesto (que cierto es cosa lastimosa). El día del Corpus Christi del año de 606 en un pueblo de 800 indios de tasa se hallaron solamente 14 indios varones en la Iglesia $\mathrm{y}$ en algunos pueblos ya no ay gente $\mathrm{y}$ se an quedado todos por acó o en los quaicos y quebradas, huyendo die sus reducciones $y$ es cierto que aunque se buelvan a reducir $\alpha$ sus pueblos de manera que estas reducciones se hiciesen al pensamiento y como se pudiesen pintar y ymaginar, dentro de 3 a 4 años quando mucho estarían tan desechas como oy están, quedando en pie la saca cada año de las mitas de Potosí.

El décimo daño que destas despoblaciones del Reino y de los pueblos del resulta es, que ya que queden algunos yndios en los pueblos ó reducciones, sobre 300 ó 400 indios que quedan allá y sobre 100 ó 150 que bienen a la mita de Potosí, ban cargando todos los servicios y tasas que estavan repartidos sobre 1,000 indios de tasa que verbi gratia, avía en el puebla y aunque algunos están en guaicos y quebradas y pagan mucho más de lo que 
deven a los caciques porque los dejen estar allí, pero esto que cobran de más los caciques se quedan con ello, como no se puede saber lo que cobraron ni de quien cobraron y assi reparten la tasa por entero entre los presentes del pueblo y los que están en la mita de Potosí, cargándoles más de lo que deven en justicia que es un agravio muy grave. (f. 169).

El undécimo daño que destas despoblaciones resulta es el no haver servicio en los tambos y caminos reales y el que ay es de mugeres, efecto pretendido por el demonio, pues con esto tienen ocasión tan próxima los pasajeros y soldados para hazer tantos pecados y ansi los tambos públicos se an vuelto casas públicas, cosa lastimosa y indigna de que se sufra entre christianos.

El duodécimo daño que resulta del venir a estas mitas como bienen agora es que, no estando aquí las mitas enteras como no lo están nunca, aunque se haga la reducción de los pueblos como la quisieren pintar los caci ques que aquí están, no pueden enterar el número de los indios que cada semana están obligados a dor y byendo esto el Corregidor de Potosí despacha jueces españoles para que vayan $\alpha$ los pueblos y hagan a los caciques que allá están que enteren los indios que faltan y estos jueces ban con 4 pesos ensayados de salario cada día y los caciques que están en los pueblos ó dan por excusa que no tienen indios o que ya los tienen enterados y estón acá en Potosí y el juez cobra 300 ó 400 pesos de salarios (porque en esto ni a de aver réplica ni falta ni dilación); para sacallos echa derramas el cacique entre la viuda vieja, donzella, huérfana, quitando sus carnerillos a la pobre yel juez se buelve sin indios con su salario cobrado y la falta por remediar, por lo cual se halla obligado el Corregidor $\alpha$ bolver $\alpha$ imbiar btro juez que haze lo mismo. Y esto es cosa lastimosa y que no cesará tampoco, cunque se reduzcon los pueblos de allá avajo, porque siempre estarón faltas las mitas y si estos jueces que ban de Potosí traen algunos indios son los aguatires y pastores que guardavan los ganados en las estancias de españoles y los dejan desamparados con grave daño de la República. Y si sacan algunos indios de los pueblos, como ellos ban a otros, los embian con algunos caciques o ylacatas y se buelven del camino con lo que se quedan las cosas como de antes estavan sin remedio y aun peor.

El décimo tercer daño que si las mitas de Potosí las tienen enteradas algunas provincias o pueblos, el Cacique ó Capitón que está aquí hurta algunos indios o para sus grangerías o para benderlos a españoles como se vee clarro, porque aun de las partes que él save que no faltan indios mingan los caciques, como no se puede saver ni averiguar que están enteradas las mitas y assi los esconden $y$ dizen que no tienen aquí todos los indios.

El décimo cuarto daño y agravio que de la falta destas mitas resulta a los indios que están aquí, que no teniendo obligación de travajar más que 4 meses en todo el año, conforme a las Ordenanzas de D. Francisco de Toledo, como están faltas las mitas los caciques les hazen travajor 6, 8, 10 Y cun 12 meses porque no tienen otros con que enterar ni plata con que mingor otros.

Décimo quinto daño y agravio: que no estando los pueblos reducidos ni con los indios que les dejó $\mathrm{D}$. Francisco de Toledo, quando ordenó que $\alpha$ cada indio le cupiese venir un año a Potosí, de 7 a 7 años, agora los nombran de 2 á 2, de 3 á 3 años, como lo a averiguado y visto el Sr. D. Francisco de Alfaro, Oídor de la Real Audiencia de los Charcas, que salió a visitar la Provincia y muchos dellos como ven que les cave tan a menudo se 
quieren más quedar de propósito aquí en Potosí o en algunos guaicos y quebradas oquí cerca, que no bolver y andar yendo y viniendo.

Décimo sexto daño: que de 100 indios que bienen a Potosí no buelven a su puebio los 40 y essos que vuelven, aun no an ilegado. quancio el curaca los ymbía a servir al tambo, al trato y contrato del cura, al trajín del Corregidor $y$ al fin tienen una vida lastimosísima y aperreada, sin dejarles descansar ni atender a sus haciendas.

Décimo séptimo daño: que los indios ni acá ni en sus pueblos tienen doctrinas ni enseñanza de propósito, porque siempre andan vagando como gitanos en España, porque en Potosí están de paso, en sus pueblos con poco asienio y sus curas acá ni allá non cognosciunt, como dice Christo Niestro Señor vultum pecoris sul, de lo que se sigue que andan como oveja sin pastor y aunque no sea otro tiempo sino el que gastan en yr y benir y este tiempo estón sin misa, si caren enfermos o mueren no tienen Sacramentos, carecen de los sufragios de la Iglesia, de sepultura en sagrado, de medicinas $y$ remedios espirituales $y$ temporales.

\section{Capítulo $3^{\circ}$-Die un remedio que se puede poner $a$ hdo: estos agravios y daños.}

Estos diez y siete doños y agravios notables se siguen todos juntos del modo de govierno y que agora ay en el venir a las mitas de Potosí de la manera que vienen oy $y$ an venido hasta aquí, sin otros innumerables menos principales de que no se haze quenta y porque estos son tan grandes $y$ tan continuos y ordinarios y las injusticias que dellos salen son tan graves no solamente podemos decir que clamor indorum venit ad Deum, sino que ya los oídos de Su Magestad y de su real Consejo y del Señor Virrey los an oído y tratan y quieren poner los remedios y preguntan quál será. A lo qual responden en suma muchos hombres graves y doctos y perlados de relijiones $\mathrm{y}$ otros cavalleros con quien se a consultado este caso en Potosí, que el remedio eficaz destos agravios y daños es hazer con grande rigor que se buelvan a entablar las reducciones y a poblar los pueblos del Reyno, sobre que estón cargadas estas mitas que bienen a Potosí, porque estando ellos enteros $y$ con todos sus indios será fácil el venir las mitas y no caverle a un indio el venir mós que de 7 a 7 años, como lo ordenó D. Francisco de Toledo y no habrá mingas estando las mitas enteras y que con esto no se trate de ninguna manera de traer aquí los indios del servicio de Potosí ni despoblados 4, 6 y 8 leguas alrededor, como algunos les a parecido porque esto tiene notables inconvenientes - el primero, que ab ontiquo jure (según Ia regla del derecho) non est recedendum sine evidenti utilitcte y que, entablar agora otro modo de govierno del que entabló D. Francisco de Toledo, ni tiene utilidad evidente ni se save como saldrá y que el otro está ya aprovado y a salido bien y que asi se conserve.

El segundo inconveniente: para poblar estos indios del servicio de Potosí en 6, u 8 ó 10 leguas al rededor, no hay tierras suficientes, donde 2 ó 3 mitas grandes (cue serán 25 ó 37,000 indios) tengan comodidad bastante para sus sementeras y pastos de ganados.

Tercero inconveniente: que desta manera parece que se despoblará el Reino, porque sacar 25 o 37,000 indios (que son 2 ó 3 mitas grandes) de los pueblos de una vez sería destruir el Reino y despoblalle de todo punto. 
Cuarto inconveniente: que el Rey avía de gastar mucho en esto y que no es necesario, porque también es razón mirar esto y no hazer gastar en iglesias, ornamentos, campanas, comprar tierras y chacras de españoles lo que no es de evidente utilidad.

Quinto inconveniente: que este remedio de poblar aquí cerca el servicio de 2 ó 3 mitas grondes de Potosí viene tarde, porque ya Potosí se acava y, para lo que a de durar, estése como se está y no se hagan nuevos gastos ni se revuelvan las cosas.

Sexto inconveniente: que los mejores testigos de que no conviene poblar las mitas de Potosí cerca del son 4 vecinos pueblos que están aquí cerca: Chaqui, 4 leguas, Puna 9, Cayca 8, Toropalca 11, Tínquipaya 7 ú 8 y estos son los pueblos más destruídos de quantos ay y más desechas las poblaciones y ansi lo serían las demás si se poblasen aquí cerca.

Séptimo inconveniente es que poblando aquí cerca de Potosí el serviciode 2 ó 3 mitas grandes se desharía el comercio que tiene Potosí en las Provincias de indios comarcanas porque, haviéndose de quedar aquellos en sus pueblos y estos poblados en estos aquí cerca de Potosí, no traerían aquí tontas comidas como traen tantas ovejas y cameros de la tierra, tantos patos y otras cosas de carne y sustento y tampoco entrarían aquí tantos cameros de la tierra para el trajín y acarreto de las cosas necesarias en un pueblo tan grande y que en él no se da ni aun ichu sino que todo es menester que le venga de fúera.

Octavo inconveniente: que en los pueblos que se poblaren aquí cerca querrían vivir luego muchos españoles $\mathrm{y}$ ocuparían los indios para que no pudiesen acudir a sus mitas de Potosí.

Noveno inconveniente: que para hazer los indios sus casas en estos pueblos y sus iglesias se avía de desentablar la mita de Potosí por un año, para desocupar los intos que lo avían de hazer.

Décimo inconveniente: que si se uviesen de reducir a estos pueblos circunvecinos faltarían indios en Potosí que se mingasen y reparasen y trajinasen $\mathrm{y}$ se alquilasen para obras y edificios.

Undécimo inconveniente: que cunque cesasen todos estos inconvenientes que parece que son temporales, por solos los dos inconvenientes de la conciencia no se puede tratar de poblar este servicio de las 2 ó 3 mitas cerca de Potosí, porque el servicio deste cerro lo cargó D. Francisco de Toledo sobre 83,000 indios tributarios que halló en los pueblos adonde mandó que biniesen $\alpha$ estas mitas, ¿pues qué conciencia puede aver que justifique que lo que está cargado sobre 83,000 indios se cargue agora sobre 25,000 que son dos mitas grandes ó 37,000 que serán tres? y que, caviéndole $\alpha$ un indio travajar según la repartición de D. Francisco de Toledo un año en 7 $y$ en ese año 4 meses, agora se le quieren cargar que travaje en 2 años 4 meses ó quando mucho en 3 años 4 meses, lo qual parece llana injusticia.

Duodécimo inconveniente de conciencia también, porque traer estos in. dios y poblallos aquí cerca de Potosí y adjudicallos al servicio de las minas parece que es hacellos esclavos perpetuos y que no falta más de que hagan scriptura de esclavitud perpetua, de que unos hombres libres estén condenados perpetuamente a las minas, que los tiranos antiguamente para dar un martirio cruel y prolongado condenavan a los mórtires a las minas y adjudicar unos hombres libres perpetuamente a la lavor destas minas parece notabilísima y clarísima injusticia y esto se descubre mós quando se haze la quenta de lo que tienen obligación de servir conforme al repartimiento de $D$. Francisco de Toledo, porque querellos agora cargar más (si cún aquello se 
haze con escrúpulo) quanto mayor lo seró el adjudicallos perpetuamente a las minas $\mathrm{y}$, para que esto se vea mejor, de 18 años tiene un indio obligación de entrar a la tasa y consequentemente está sujeto al nombramiento de las minas de Potosí y de 50 sale de ambas obligaciones y este indio a de venir, según la Ordenanza de D. Francisco de Toledo, de 7 a 7 años a Potosí, que en 32 años le caven quando mucho 5 años, pues ¿quién puede $\alpha$ consejar que por 5 años de servicio se les obligue a que estén toda la vida adjudicados a las minas? parece injusticia clara $\mathrm{y}$ agravio manifiesto y por estas razones se da el parecer puesto en el $\mathrm{N}^{\circ} 11$ de que se haga la reduc ción general a sus pueblos y vengan las mitas de la manera que an venido hasta aquí.

Capítulo $4^{\circ}$-De otro modo con que parece que se podían entablor y perpetuar estas minas y servicio de Potosí con mucha mayor siguridad de conciencia y sin tontos escrúpulos, antes quitados muchos de los que asta aquí a crido y agora ory y este es el parecer de los que coquí firmamos.

Ninguno puede negar que en el venir las mitas a Potosí como lo entabló y mandó D. Francisco de Toledo a tenido el Rey y su Real Consejo de las Indias muchos escrúpulos y el que tienen sus Virreyes le deponen con que el Rey y Consejo les manda governar por las Ordenanzas de D. Francisco de Toledo $y$ de que este medio de mita tenga escrúpulo y aun escrúpulos y muchos, traslado al haverse retractado el Arzobispo de Lima, D. Jerónimo de Loayza a la ora de la muerte, quando se veen las cosas más claramente, el P. Fray Juan del Campo y otros grandes letrados que dieron parecer a D. Francisco de que se hiziese y después dixeron, en su vida, que no savían lo que avían firmado, por quanto fueron considerando mejor los agravios de los indios obligados a esta mita y la experiencia fué mostrando las grandes injusticias que se seguían a los que $\alpha$ ella venían y evidente prueva es de que ay escrúpulo, pues que tan graves theólogos y letrados de este Reyno que juntó Don Luis de Velasco en Lima, por orden de Su Magestad $\alpha$ ver si se podían dar algunos indios a nuevos minerales que se descubrían en este Reyno, todos unánimes y conformes sin discrepar ninguno, respondieron que no, ni por pienso ni se tratase jamós dello; luego si no hubiera escrúpulo en lo que se hizo al principio (que no se agravaran antes se aligeraran las circunstancias) lícito fuera agora aconsejar que se hiziera tam bién y no vale nada la razón de que el Rey puede lícitamente cargar con tributos de servicio personal a sus súbditos, como se haze en Italia, en Frandia y en España se quintan los hombres para la guerra \& porque estos servicios son por tiempo limitado, quando sucede alguna grave necesidad \& $Y$ para defender su propia tierra, a lo qual están los hombres obligados de derecho natural, como partes al todo y porque ellos no acuden a esta obligación es bien que aya superior qua los compela a que acudan en este particular a esta obligarción. Pero ¿quién diró que los indios tienen obligación natural de travajar en las minas para sacar plata para todo el mundo \&? y asi echar pecho ordinario para toda la vida y este servicio y travajo personal sobre hombres libres no se save que en ninguna parte del mundo se haga y aquí no lo condenamos claramente, pero lo que queremos provar es que tiene escrúpulo $y$ allá, $\alpha$ quien pertenece, lo verá y si algunos theólogos uviere que claramente justifiquen las mitas, como las puso, ordenó y enta- 
bló D. Francisco de Toledo, a lo menos no es de creer que abrá ninguno que no tenga muy grandes escrúpulos de aconsejar que se continúen con los agravios y ynjusticias que oy se hacen (de que dará cuenta $\alpha$ Dios quien puede y deve remediarlo y no lo remedia) y no ay duda sino que quien diora traza de que continuóndose la lavor del cerro de Potosí se continúe sin agravios, injusticias, fuerzas de indios ni estos escrúpulos, 0 a lo menos con menos, que este parece que dará mejor parecer y assí es el nuestro de que para que el Rey, el Consejo, los Señores Virreyes y sus Ministros no tengan tantos escrúpulos ni los indios recivan tantos agravios se pueble el servicio de Potosí de dos o tres mitas: estas 2 ó 3 mitas, grandes, aquí cerca de una vez, pero porque esto se puede hacer de una de dos maneras, los distinguiremos aquí para que se entienda la que es mala y no se deve seguir y la que es buena y se deve abrazar. El poblar en Potosí ó cerca lo primero lo puede hacer el Virrey, diciendo que conviene esto y que para ello se tomen 25 ó 37 mil indios de los repartimientos y pueblos de donde bienen las mitas oy y que para esto se quiten ó se fuerzen a los que les cayere $y$, quieran o no quieran, se haga esta población, porque ansi conviene \& y desta manera somos de parecer que de ninguna manera se haga ni se trate della, porque aunque esto fuera menor pecado que no hazerlos venir como vienen agora ynvoluntarios $y$ forzados $y$ a los indios se les siguieran menos daños y agravios de aquellos 17 que pusimos en el Capítulo $3^{\circ}$, como constará discurriendo por cada uno dellos, pero no es lícito de ninguna manera como prueban bien los theólogos a uno que está determinado a hazer un pecado maior aconsejarle que haga otro menor, como consta de la Divina Scriptura, donde todos condenan a Loth $y$, si alguien le excusa como Santo Thomás y Cayetano, el uno es por ignorancia y el otro por inadvertencia $y$ turbación repentina $y$ ofrecimiento de materia de menor daño, pero de suyo todos lo condenan a pecado mortal, al aconsejar que se haga un pecado mortal menor por evitar otro mayor, como todos condenan al patriarca Judá, quando (Gen. 37) aconsejó a sus hermanos que no matasen a su hermano José sino que le vendiesen a los ismaelitas \& así acá, aunque los daños que reciven los indios del modo de las mitas que agora están entabladas son mayores, pero no nos atrevemos a aconsejar que se traigan y pueblen aquí los indios contra su voluntad, aunque los daños e inconvenientes que desto resultarían serían menores. Lo que se dá por parecer es que a los indios se les tome su parecer y con su voluntad y libre consentimiento queriéndose quedar aquí y poblarse aquí en Potosí, 4 ó 6 ó 8 leguas alrededor, se queden $y$ se hagan estas poblaciones y reduciones aquí cerca $Y$ se entablen aquí dos o tres mitas grandes, como luego diremos y al inconveniente que luese se ofrece de que si $\alpha$ de ser con su voluntad no se querá quedar nadie y asi es trustráneo $\mathrm{y}$ en el aire este medio, se responden dos cosas: La primera que ay aquí en Potosí indios tan diestros y que hallan tanto interés en labrar las minas y estón tan aquerenciados a la lavor deste cerro que ya ellos con el uso no sienten travajo y, si lo sienten, el interés y ganancia tan grande que tienen (ganando 18 y 20 pesos cada semana) vence qualquiera dificultad y están tan aficionados y habituados y fáciles en este travajo que a palos no los echarớn de aquí $\mathrm{y}$ asi se vé y experimenta que ay muchísimos indios que voluntariamente travajan todo el año y aun muchos años. La segunda cosa que se dice es, que a los demás indios que no están tan diestros y aficionados a Potosí se les hagan tantas y tales comodidades que ellas mismas les obliguen y les conviden a quedarse voluntoriamente $y$, a que, dándoles escoger $\alpha$ cada uno que libre $y$ voluntariamente diga quál quiere más, volverse $\alpha$ su pueblo donde $\alpha$ de te- 
ner servicio de tambo, traxin de soldado, ropa del Corregidor, trato y contrato del cura, servicio de ciudad, tasa del encomendero sin otras muchas cargas de llamamiches y pastores de ganados y vejaciones de Curacas, pero al fin a de vivir allí libre ya de las obligaciones de la mita de Potosí ó quedarse aquí poblado en Potosí o en los pueblos alrededor del por yanacona del cerro con tales y tales comodidades, que serán cinco: La primera, que para él ya no ay trajin ni servicio de tambos ni ser mitayo de ciudad ni $\alpha$ de haver Corregidor que le haga hacer ropa ni cura que le ocupe en sus grangerías, si no de 3 á 3 años (si se pusiesen aquí tres mitas grandes) ó si se pusieran dos, servir de 2 ó 2 años, cuatro meses en el cerro de Potosí; de manera que en 3 años, cuatro meses en el cerro ó en 2 años cuatro meses, y 2 años y ocho meses ó 1 año y ocho meses a de hazer lo que él quisiere, ser carvonero, carnicero, maderero o chacarero o estarse en su casa con sus hijos y mujer, al fin que por fuerza no le apremiarán a nada $\mathrm{y}$ si le apremioren a algo seró porque no se esté holgando, como lícitamente lo pueden hazer y hazen las repúblicas para evitar la ociosidad de sus vecinos, compelerlos a algunos servicios moderados por poco tiempo y por buena paga.

La segunda comodidad es que por el tiempo de los cuatro meses que travajare en el cerro no pagará ninguna tasa. La tercera comodidad, que por el tiempo que no se ocupa en el cerro que son 2 años y 8 meses, si se ponen tres mitas ó 1 año y 8 meses, si se pusieren dos mitas, no pagará más de la mitad de la tasa que antes pagava, de*manera que si antes pagava 20 pesos de tasa, quedándose aquí de su voluntad, no pagará más de 10 y al respecto dello, más ó menos que agora pagan.

La cuarta comodidad que la ropa de tasa, maiz y chuño que el Rey tiene en los repartimientos y corregimientos desta Provincia, se la dará Su Magestad al precio yue se a vendido 3 ó 4 años atrás en las almonedas del Rey, en lo que no pierde $\mathrm{Su}$ Magestad ni un real y ganarán muchísimos ducados los indios que se quedasen aquí en Potosí y así les seró esta grandísima comodidad.

Lo quinto les podrían hazer otras comodidades de privilegio o exenciones que los Señores Virreyes, informados de las justicias de acó o de la Audiencia juzguen que les serían de alguna consideración y de algún gusto $\mathrm{y}$ que les pusiesen algún apetito para escoger voluntariamente el quedarse, sirviendo a este cerro, como sería que por ningún delito los pudiesen trasquilar, lo que ellos estiman en mucho $u$ otros semejantes privilegios. $Y$ descendiendo al modo particular de cómo esto se avía de hazer, parece que agora bienen aquí cada año, de la mita grande que llamamos, 12,500 indios، aviase de poblar aquí tres mitas grandes que son 37,500 indios y assi les cabría a cada indio el travajar 4 meses en el cerro en 3 años que no es mucho trabajo y es menor sin comparación que el que tienen agora, que travajon 4 meses en un año de obligación y quando se on acavado, el cacique, porque no a venido la otra mita, les haze travajar otros 2 ó 3 meses y luego, por el que se huyó, otro mes y luego, por no sé qué lo demás del año y algunos comienzan el segundo, porque el cacique no tiene con quien suplir ni plata con qué mingar y esto pasa asi puntualmente no en pocos sino en muchísimos indios y casi con los más, lo qual es notabilísimo agravio y daño que se les hace $y$ lo peor es que esto no tiene ni tendrá jamós remedio, aunque se pueblen los pueblos avajo, si an de venir las mitas de fuera, porque jamós estarón tan cumplidos que no sea necesario hazer esto muchísimas veces, aunque confesamos que sería entonces menos y si pareciesen muchos 
37,500 indios, asi para la despoblación de los pueblos de avajo como porque no cabrían en las tierras que ay alrededor de Potosí se podían tomar 25,000 , que son dos mitas grandes y les cabría en 2 años 4 meses, aunque parece poco descanso pero es más que el que agora tienen sin comparación y declarándoselo bien y siendo voluntario no parece que ay que tener tanto escrúpulo pues es contrato ultro citroque libre y voluntario y escogido por ellos, scientes et prudentes, a quiengs no se haze injuria, aunque parece que forzándole a uno que escoja una de dos, lo que escogiese no le es ton libre, pero al fin estaráles esto mucho mejor sin comparación.

\section{Capítulo 5!-Del inconvenlente que esto tiene grandísimo que es perder el Rey tanta cantidad de renta de las tasas en ca- da un año y perder otro tanto los encomenderos y del re- medio que esto tiene.}

A esto se responde, lo primero, que por el bien espiritual y quietud de conciencia y librarse de muchos escrúpulos Su Magestad, con el quedarse aquí los indios libre y voluntariamente (con lo qual no avía que tener ya tantos temores en la lavor de Potosí), no era mucho que Su Magestad perdiera 70 ó 80 pesos de renta que le podían rentor estos 4 meses que se quitan $\alpha$ los in. dios de tasa, conforme a la comodidad $2^{\alpha}$ del $\mathrm{N}^{\circ} 17$ y la mitad de la tasa que se les quita allí en la comodidad $3^{\alpha}$ y la tasa que pierden los encomenderos, podíasela el Rey recompensar en tributos vacos, pero si el Rey y sus Ministros no quieren este medio, algunos on propuesto otro y no parece muy justificado, aunque miróndolo más despacio, el Señor Virrey, los theólogos $\mathrm{Y}$ letrados y Oídores de Lima podría ser que lo hallasen no con tanto rigor y es que, pues los indios que quedon en sus pueblos antiguos quedan ya sin esta carga de venir a Potosí con tantos gastos de carneros, de pérdidas de chácaras y bienes temporales, a estos se les dijese que pues los relevan de tantos gastos, a de ser con condición que paguen un tercio más de tasa ó un tanto 'mós, tal qual, bastase a enchir la tasa como ontes estaba, para que con lo que dan allá de más se supliese la que dan aquí de menos y se ioualase como antes estava, sin pérdida del Rey y de los encomenderos, pero el tercero medio podría ser el que más quadrase y es que si se poblasen aquí 25,000 indios voluntarios los 10,000 v. gr., poco más o menos, serón tributcrios del Rey y los 15,000 de encomenderos, todos estos 25,000 voluntarios $y$ que se adjudican ellos al servicio de Potosí havían de ser tributarios del Rey y ia rebaja que se haría en los 10,000 que antes tenía el Rey, se supliera y aun sobrara con lo que le an de dar los 15,000 que entran en su corona de nuebo, de manera que ya aquí el Rey no solamente no pierde poco, aun gana y aumenta de su renta y al respecto, mesmo avía de ser si se pusiesen 37,500 indios (que son las tres mitas grandes) y a los encomenderos (que digamos v. gr., que cada uno pierde 1,000 pesos de renta, poco más o menos), por aquelles indios que se le quitan de sus pueblos para traerlos aquí a Potosí les diga el Rey y el Virrey, en su nombre: por eso que se os quita os doy la encomienda por una vida más, de manera que el que la tiene encomendada por una vida la tendrá por dos y el que agora la tiene por dos vidas la tendrá por tres, en lo qual no pierde el Rey nada y los encomenderos ganarón mucho y se holgarán notablemente y $\alpha$ los indios se les hazen aquellas dos comodidades tan grandes $y$, preguntados algunos caciques y Capitanes de Potosí algo en razón desto, dizen que les estaría maravillosamen- 
te. Y viniendo al modo material que esta redución del servicio de Potosí aquí ó aqui cerca avía de tener no es propio desta dificultad y duda que se pregunta, aunque en dos palabras se podía decir lo que muchos hombres graves $\mathrm{y}$ experimentados an dicho: que la mita de estos indios se avía de reducir y poblar dentro de Potosí, donde tienen ya hechas 14 parroquias y muy bien adornadas, donde ay ornamentos, campanas, tienen ya sus curas, con gruesos sínodos, tienen su ospital, médicos, cirujanos y medicinas, tienen sus casas hechas y aquí cerca se les podía dar algún modo de chacarillas, aunque la mejor chácara para los que viven aquí es el cerro, ingenios, trajines, en lo qual ganan mucha plata y con esta hallan en la plaza todo lo que an menester y en lo de las poblaciones que se avían de hazer cerca de Potosí diremos avajo $\mathrm{N}^{\circ} 25$ quando respondamos al segundo inconveniente puesto en el No 12 .

\section{Capítulo 69 (2). -De las grandes utilidades que poblar aqui ó aquí cerca el servicio de lass mitas de Potosí tendría. Nং 21.}

Las utilidades que de poblar estas mitas de Potosí, en él ó aquí cerca* son muchas $y$ todas se pueden reducir $\alpha$ dos cavezas: la $1^{9}$ es de los vienes temporales y la $2^{\%}$ de los vienes espirituales, que son los que se pretenden principalmente en este parecer $Y$, comenzando por la primera cabeza de los bienes temporales, son muchísimos: $1^{\circ}$ cesará el segundo agravio de la pérdida de las chácaras, aciendas, \&. Cesará el $3^{\circ}$ agravio de hacerles venir de 180 y 160 y menos leguas... cesará el $4^{\circ}$ agravio de muertes por los caminos... cesará el $5^{\circ}$ daño... que es no dejarles tener buenas haciendas ni ser ricos... Cesará el $7^{\circ}$ daño de los mozorunas... Cesará el agravio grande de los mingas... porque no abrá ausentes ni heridos... Cesćrá el $9^{9}$ daño de la destrucción del Reyno y la despoblación \& Cesará el $10^{\circ}$ daño de no estar tan cargados las partes y el $11^{\circ}$ de haber hombres que sirvan en los tambos y caminos... Cescría el $12^{\circ}$ agravio de los juezes, porque estando acá poblados las dos o tres mitas, como se a dicho, no abrá que ir allá por ellos. Cesaría el agravio $13^{\circ} \ldots$ porque no podría decir el cacique que no tiene enterada la mita, aunque la tenga como agora sucede... Cesaría el $14^{\circ}$ y el $15^{\circ} \mathrm{y}$ el $16^{\circ}$ daño o agravio, como consta que se siguen, y a Potosí se le seguiría la grandísima comodidad, de estorvar que en Oruro (que son las minas que agora se an descubiento) a la ida y a la vuelta no le detuviesen los indios... y si alguno dijere que ni cesarón estos agravios ni dejarón de resultarles a los indios otros mayores, si se poblasen $\alpha q u i ́, \alpha$ esto se responde que más puesto en razón y cierto es decir, que cesarán, pues se pone medio eficaz para que cesen y se quita la causa única de donde ellos nacen... Pero no es esto lo más principal desta traza de entablar y poblar a Potosí de una vez el que cesen todos estos agravios... sino que cesen los (daños) espirituales de conciencia y quitar escrúpulos de la del Rey, Consejo, Virrey y Ministros de Su Magestad... y lo que parece muy cierto es que con las circunstancias que oy se hace... ya que se justificase el modo con que la entabló $D$. Francisco de Toledo, no parece que abrá theólogo que se atreva a justificarla, sino que carga gravemente sobre quien puede $y$ deve remediarlo y no lo remedia el voluntario indirecto que pone Santo Thomas

(2) Desde aquí se resume la materia del capítulo. 
(19 $\left.2^{\alpha} q .6^{q}\right)$ y con él todos los theólogos y si con quedarse aquí, los indios de su voluntad se justifica todo esto, en gran parte y se quitan muchísimos escrúpulos ¿qué hombre abrá, theólogo o no theólogo, que se atreva $a$ no sentir que es mejor que se queden aquí? ... y es de desear que no venga algún tiempo en que a los que contravinieron a que estas mitas e yndios no sirvan libre y voluntariamentea este cerro, no se les pueda decir: merito haec patimur quia peccavimus in tratrem nostrum \&.

\section{Capitulo 7-En que se responde a las dificultades e inconve- nientes que se pusieron a este modo de entablar la mita de Potosí de una vez en el Capítulo $3^{\circ}$.}

Lo primero, antes de responder aquellas 12 dificultades e inconvenientes se nota lo que se dijo en el Capítulo $3^{\circ}$, que cualquier medio que se tome, ora sea aquel ora sea este, a de tener dificultades e inconvenientes y que las que en aquel Capítulo se oponen no quedarán tan llanas con la solución que aquí se les dará que no tengan sus réplicas y entre tantas dificultades como quedarán en pie de una parte y de otra, abrá de entrar la determinación del señor Visorrey con el acto de la prudencia que es el juzgar, como diji mos, quales dificultades son las menores para romper con ellas y executar lo que tiene menos inconvenientes $y$, lo segundo, se presupone lo que se dijo en el Capítulo $1^{8}$ que los mayores inconvenientes son los del alma, de la conciencia y remordimiento della... Al $1^{\circ}$ inconveniente que se pone en el $N^{\circ}$ 12 se responde que ab antiquo jure non est recedendum sine evidente utilitate y aquil evidente utilidad ay, pues el asegurar las conciencias del Rey y de sus Ministros con la libertad de los indios... no por evidente sino por casi evidentísima utilidad se deve tener... $\mathbb{A} 2^{\circ}$ inconveniente se responde que 10 ó 12 leguas alrededor de Potosí (porque no se deven alejar más estas pablaciones) con lo qual cesan los temores vanos de que si estuviesen cerca de los indios de guerra se yrían estos indios allá, lo qual no es probable, aunque lo estuvieran, porque agora están muy cerca algunos pueblos y no se va nadie, (luego tampoco entonces). Dentro de esta distancia de 10 ó $12 \mathrm{le}$ guas, según dicen los Corregidores de Porco que es su corregimiento, ay muchas tierras que puedan darse a estos yndios, que aunque no ay ningunas 0 pocas que no estén ocupadas, pero $\alpha$ los españoles que las tienen, se les compren las que fuesen necesarias $\mathrm{y}$ en esta distancia de 4,6, 8, 10 y 12 leguas alrededor de Potosí están los pueblos de Puna, Chaqui, Tacobamba, Tinqulpaya, Yura, Caica, Toropalca, Visisa y otros, donde casi todos tienen poquísimos indios $y$ tienen muchas tierras $y$ se podrian acomodar muchos indios, dos o tres tantos de los que ay por el Repartimiento y ay muchas chácaras de españoles que las podría comprar el Rey y descender más en particular sería ad singula adhoerere... A la $3^{q}$ dificultad se responde, que antes esto parece que sería poblar el Reino y asentallo de una vez, porque a Juli $v$. Gr. (3.011 indios de tasa), mejor le estaría quedorse con 2,200 indios perpetuos y de asiento que no tener los que agora tiene con tanta inquietud... A la $4^{q}$ dificultad se responde que no abró el Rey gastado plata más bien empleada que en la que importa al asegurar su conciencia y quitar tantos escrúpulos... quanto más que no gastará 200,000 pesos corrientes ni con mucho y a trueco de conservar $1^{\prime} 300,000$ pesos de renta cada año... Al $5^{\circ}$ inconveniente se responde que con hacerle este beneficio a Potosí, que el de avajar los quintos y los azogues comenzará agora y con estos tres beneficios: tendrá el Rey más renta de la que a tenido hasta aquí y se perpetuará \&. 
Al $6^{\circ}$ se responde que es yerdad que los pueblos más desp blados son los que están aquí cerca, pero no es lo primero, porque tienenl Corregimiento distinto y chácaras de españoles, matanzas de las estancias y se quiere estar mas a fuu en Potosi; pero entonces el Corregidor $d$ : aquí avic de ser Corregidor de ios pueblos del sev: $v^{*}$ cio y assí con su mandacis nadie le sacaría indios... Al $7^{\circ}$ que se concede iibenter que no arria tantos indios que entrasen y saliesen de las mitas, pero de su voluntad los comarconos an de traer aquí las comidas porque no tienen donde gastallas y los de la Provincia de los Pacajes y Chucuito an de traer aquí sus carneros forzosamente, porque de tanta copia no tendrá salida en otra parte ni tan bien...

Al $8^{\circ}$ inconveniente se dize que el Corregidor de Potosí no deje vivir en los pueblos a ningún español. Al $9^{\circ}$ inconveniente, que no a de cesar la mita ni un punto porque 4,000 indios que sirven estense ocupados, pero 21,000 harón un Reyno, quanto mós 5 ó 6 pueblos $\mathrm{y}$ al fin esto es ad singula adhaerere... Al $I^{C}$ inconveniente se responde que aquí en Potosí avía de estar poblada la mayor parte de estos indios; que agora abrá 30,000 indios de travajo y que sean 20,000 con lo qual se prueva que abría aquí todos los que fuesen necescrios. Al $11^{\circ}$ inconveniente que no solamente no se encarga la conciencia en cargar esta mita toda sobre 25 o sobre 37 mil indios, estando agora cargada sobre 83,000 con todas las demás cargas de mita, de tambo, trajín de Corregidor y de Cura y servicio de ciudades y de españoles, con otras 160,000 cargas que agora cargan sobre ellos y las idas y benidas sin paga... luego mejor les está sin comparación sin estas cargas y relevándoles de todas ellas, servir de 2 a 2 años 4 meses y que esto sea puntual que viene $a$ ser un año en 6 años y lo que quita el escrúpulo quasi del todo es que esto $a$ de ser con su boluntad y escogiéndola ellos. Al $12^{\circ}$ inconveniente se dize que el servir a las minas como sirven los indios en Potosí aunque es muy gran travajo pero no se debe comparar con el echar los tiranos a los mártires a las minas porque ni allí les pagavan su travajo ni tenían ospitales ni curas ni sus mugeres e hijos ni se yvan a dormir a sus casas ni tenían otras muchas comodidades ni tampoco se puede decir que agan servicio de esclavitud, porque antes seró la gente más descansada que aya en ei Pirú, porque tendrón sus chóccaras conocidas, sus casas, sus buenas pagas... y no es buena razón decir que si esto fuera mejor D. Francisco de Toledo lo entablara, que entonces era más fácil... porque este es el modo de govierno humano ir mejorando las cosas que la experiencia y el tiempo muestran que estarán mejor de otra manera...

\section{Capítulo 8-.-De la conclusión de todo lo dicho.}

Brevemente se resume todo este parecer en 12 conclusiones. La $1^{\text {q }}$ que para el bien temporal de Potosí está mucho mejor que dentro del y alrededor, dentro de 8 ó 10 leguas, se pueblen los indios porque tendrá más servicio más a mano y se aumentará mucho la lavor del cerro y beneficios, como consta ciaramente al que lo considera bien. - $2^{\alpha}$ conclusión: que $\alpha$ los azogueros $y$ ail Rey para sus quintos les está mejor, para su aumento, que no aviendo mingas no hurtarían los mineros a sus amos. $3^{a}$ que al Corregidor de Potosí le estaría esto maravillosamente, aun para lo que es aliviarle de trabajo corporal en el entero de las mitas, pero mucho mejor le estaría para su bien espiritual pues con esto se le quitarían mil escrúpulos y perplejidades que se afrecen cada día en el hazer enterar las mitas, en el imbiar preces \& y en otras cosas que ellos saven y experimentan.- $4^{a}$ conclusión: $A 1$ bien corpo. ral de estos indios les está esto mejor porque cesarían todos los agravios del 
Capítulo $2^{\circ}$, tendrían haciendas conocidas acá y allá, chácaras, multiplicarían con la quietud. . . - $5^{\alpha}$ conclusión: $\mathrm{Al}$ bien espiritual de los indios les está mejor para que los conozcan sus curas, para que los doctrinen, enseñen, no mueran sin Sacramentos por esos guaicos ó caminos.

$6^{\alpha}$ Conclusión: Al Reyno le estaría muy bien porque estarían las reducciones de avajo más conservadas sin huirse los indios a los guaicos. - $7^{\text {a }}$ conclusión: A quien mejor le estaría es al Rey... porque no tendría escrúpulos, $\alpha$ lo menos serían mucho menos y de menos consideración, consiguientemente está esto muy bien al Señor Virrey y a todos los ministros de Su Magestad. $8^{\alpha}$ conclusión: Esta opción y libertad que se les a de dar a los indios para que escojan no deve ser, como algunos dizen, tratándolo con los caciques sino con cada indio en particular porque de otra manera no sería tan sigura pues que el indio particular es el que digamos vende su libertad a trueque de aquellas comodidades... $9^{9}$ conclusión: Esta reducción y darles $\alpha$ estos indios a escoger desta manera parece que deve comenzar hacerse primero con los indios que actualmente se hallasen en Potosí porque estos son los que están aquí más aquerenciados... 10 conclusión: Quando no se hallasen 25,000 indios que quisiesen quedarse, sería acertado que se poblasen los que escogiesen el quedarse acá y se rebajasen a los pueblos de donde fuesen que viniendo las mitas adelante y viendo las comodidades que Estos tienen aquí se aficionarán a quedarse y quando esto no se hiciese en un año o dos se haría en tres y cada año se irían quedando algunos...

$11^{\alpha}$ conclusión: El parecer de que se haga la reducción en los pueblos de avajo y que en lo demás de las mitas se quede como se está y lo entabló el Sr. D. Francisco de Toledo, comparado con que los indios sirvan aquí libremente, parece muy escrupuloso pues es continuativo de los 17 cgravios ó a lo menos de casi todos ellos, como lo pusimos en el Capítulo $2^{\circ}$ y aunque la ley, como se dize, no pretende estos agravios... no pueden apartarse iácilmente de la sustancia de la ley y... a quien pone la ley ó la conserva ó aconseja que se continúe no se pueda dejar de atribuir los dichos agravios muy directamente pues que qui causam damni dat damnorum dedisse videtur... La $12^{\text {a }}$ conclusión: Que el poblar los pueblos abajo, aunque sea con toda la perfección que quisieren si dellos an de venir los mitas como hasta aquí, lo uno no durará nada ese remedio porque dentro de 3 ó 4 años se volverón $\alpha$ deshacer las reducciones y a estar el Reyno como agora se está y con las mesmas dificultades porque es imposible con la saca de las mitas de cada año conservarse las reducciones como agora las pusieren, pues los que están acá, los que vienen, los que buelven y los que se an de quedar en los guaicos han de deshacer la reducción forzosamente... Pero lo peor de esto es que con venir las mitas como hasta aquí an venido, no se quitan escrúpulos ni los 17 inconvenientes del Capítulo $3^{\circ}$ cesarán jamás, ni las conciencias del Rey, del Consejo y del Señor Virrey y demás ministros nunca estarán sin escrúpulos y asi no se remedian con aquella traza y parecer los inconvenientes de conciencia sino solamente se ocurre a alguna incomodidad temporal que agora ay que es a lo menos que en este parecer se atiende y esto es lo que parece en el Colegio de la Compañía de Jesús de Potosí y a los demás que aquí firmamos. Fecho en Potosí a 31 de Marzo de 1610 años.

Valentín de Caravantes - Antonio de Vega - Alonso Truxillo - Joan de Guemes - Agustín de Aguilar - Francisco Guerrero - Sebastián Delgado - Martín Pérez de Gallete. Biblioteca Nacional, Madrid.-Ms. 2010: f. 163-181. (1).

(1) V. Vargas Ugarte Mss. Peruanos. - Tom. I, pág. 206. 


\section{Carta anua del P. Diego de Torres al P. General Claudio Agua- viva. Córdoba del Tucumán. 15 de Febrero de 1612, sobre el servicio personal.}

"Ha sido común en toda la Provincia y particularmente en estas dos governaciones de Paraguay y Tucumán el padecer todos los nuestros en todos los puestos muy graves persecusiones por la verdad y justicia, defendiendo. con más fervor que nunca la libertad de los indios y apoyando con sermones, pareceres y en pláticas, particulares la mucha justificación, con que la Magestad del Rey Cathólico Nuestro Señor manda quitar el servicio personal y desagraviar a los indios xripanos, para que ellos vivan como tales y los infieles se redusgan a la fée y recivan el evangelio. Ha sido forzoso hacer los nuestros este oficio con más fervor este año que los pasados por haver venido a estas dos governaciones un oydor (1) de Su Magestad a poner los indios en libertad, tassarlos y desagraviarlos; y así como el demonio se le ha opuesto con estraordinaria violencia y muchos estorvos, assi también el Señor Obispo de Tucumán (2) y algunos religiosos de Señor S. Francisco han deffendido la voluntad y. obediencia de las dos magestades y ayudado al visitador apostólicamente, no sin costa, o por mejor decir, ganancia de algunas persecuciones y trabajos, pero en ellos ha querido la divina bondad aventajar $\alpha$ los nuestros, haciéndoles el demonio más cruel guerra, como si le fueren los principales enemigos, mirándoles y tratándoles como a tales los principales interesados en este negocio, y no sólo negando las cortas limosnas que solían hacer, pero estorvando a los pocos que las han querido hacer, y aun en oyr los sermones y missas de los nuestros, los quales dicen han sido la principal causa de que se quite el servicio personal... El servicio personal es un modo de esclavitud que en los indios impusieron contra la voluntad de los Reyes de España los conquistadores primeros, sirviéndose dellos y de sus mugeres $\mathrm{y}$ hijos desde que saben andar hasta que mueren $\mathrm{Y}$ aprobechándose dellos en quantos ministerios $\mathrm{y}$ grangerías ha podido inventar el demonio con que ha impedido el conocimiento de Dios en los xpanos, y el usso de los Sacramentos y la conversión de los infieles y la conservación de los unos y los otros; de los fieles con estos trabajos, de los infieles con las muchas querras y malocas, que lloman, que se las ha hecho. Los ministros destos úgravios y exactores han sido unos hombres vajos, y como forajidos, que sin Dios y sin ley vivían entre los indios puestos por los encomenderos como mayordomos suyos; porque $\alpha$ ellos les estaba prohibida la entrada en los pueblos, y a estos hombres llamaban pobleros de los quales el oydor de Su Magestad ha descubierto en esta visita (con haverla hecho $\alpha$ sobrepeyne por justos respectos) tantos delictos que no es de creer que sus amos los savían, ni quien pudiesse tratar del remedio...

(1) D. Francisco de Alfaro.

(2) D. Fernando de Trejo. 
Los Reyes chatólicos y sus Virreyes han muchas y diversas veces mandado quitar este servicio personal (aunque no es posible haverse conocido hasta aora los graves daños espirituales y temporales que cousaba) y todos los governadores hhan tenido cédulas de Su Magestad en que les mandaba lo mismo, pero ninguno se atrevió a intentarlo, ni aun los predicadores $\alpha$ tomar en la boca el nombre de servicio personal para reprehenderlo, y muchos confessores han passado por él como si fuera cosa que la costumbre la hiciera lícita: y aun aora no han faltado, personas eclesiásticas, pero sin letras, que han hecho las partes de los encomenderos, y personas interesadas, y sido principaies instrumentos y causa para que no se haya recibido también lo que Su Magestad siempre y aora ha mandado, y el Señor Obispo y todos los de la Compañía y los demás Padres de S. Francisco deffendemos. Y como a Su Señoría que ha procedido apostólicamente y a los demás nos llaman y tratan como a enemigos de la patria y assoladores de la tierra; a ellos los aclaman por los deffensores y padres della.

Una de las particularidades que este negocio ha tenido de consideración para tratarle brevemente desde sus principios es, que un hombre pobre desta governación de Tucumán, de nación portugués, movido por ventura a lo que se puede entender de Dios Nuestro Señor y de una natural compasión, vistos los agravios que en estas tierras se hacían contra los indios con este servicio personal, haura once años que se movió a ir a España con algunos memoriales a representar a Su Magestad y a su consejo lo que padecían los indios, $y$ aunque otras muchas personas de mas autoridad debían de haber tratado de lo mesmo, el lo hizo con tanto fervor que gastando en esta pretensión la hacienda que tenía, sacó cédula apretada de Su Magestad en que mandaba al Presidente de los Charcas venir a esta visita. Y yo ví en España $\alpha$ este hombre y comunicándome su justa pretensión $\mathrm{y}$ cun por ventura $\alpha$ vergonzándome de no haver tratado yo lo propio con calor; le hize dar entrada y encomendé a los nuestros para que le ayudasen. Y quando volví del Reyno, le topé en el camino muy gozoso de haver salido con su pretensión y que se pusiese audiencia en Chile. Al cabo de quatro años que venía con el Visitador le obligaron los interesados a que se fuesse al Reyno de Chile, y llegando a la Provincia de Cuyo en la qual hasta aora se conserva este servicio personal le comenzó también a hacer guerra, $y$ tubo con los vecinos de una ciudad llamada $S$. Ju' muchos enquentros, passo a la Audiencia de Chile y proponiendo a aquellos Señores los medios con que se podían remediar aquellos agravios, le dieron provisión para ello y le hicieron executor $\mathrm{y}$ haviendo llegado a la ciudad de Mendoza y siendo bien recibido volvió a la de $\mathrm{S}$. $\mathrm{Ju}^{\circ}$ y al cabo de dos días estando almorzando una mañana se quedó muerto. La causa no se sabe...

La segunda particularidad que este negocio ha tenido de mucha consideración... fué mover (Nuestro Señor) a V.P. para que fundasse esta Provincia $\mathrm{y}$ que los de ella fuessen como precursores y ayudadores del Ministro del Rey para negocio de tanta importancia, mandándome V.P. muy a caso quando la vine a fundar, en el fin de una carta, que quitasse el servicio personal de los indios que servían en nuestro collegio de Chile, y que confiriese este punto con el Padre Provincial del Perú que havía tenido hasta aora a cargo aquel collegio. Hícele y para tomar mejor resolución le pareció al Padre Provincial del Perú juntar en el collegio de Lima donde estóbamos dieciocho o veinte Padres de los más graves y doctos, que la Compañía ha tenido en estas partes y entre ellos al Padre Luis de Valdivia, que havía gobernado el Collegio de Chile algunos años. Convinieron todos los padres sin faltar alguno en que el servicio personal era contra todo derecho 
y que aunque el que havía en nuestro collegio era con toda moderación sin servir las mugeres y pagando muy bien a los indios, estaba obligado a quitarle, y de allí quedé enterado en la obligación que también me corría de quitarlo en las casas destotras dos governaciones y de que los nuestros assi predicadores como confessores persuadiessen lo mismo a los encomenderos y los comenzassen a disponer para quando llegasse el orden del Rey. Passe a Chile y executando el orden de V.P. con nuestros indios, causó a los vecinos mucha novedad y algún desconsuelo saver que havía obligación de consciencia para ello y assi se movió allá con esta occasión la materia, y de lo que allí ha passado y el suscesso que terna con la venida del Padre Luis de Valdivia se diró en el anua del año que viene con el favor de Dios.

Vuelto a esta governación y llegado a la del Paraguay haziendo lo mesmo que en Chile fué mayor el sentimiento de los vecinos, y nuestra obligación de procurarles sacar de la ignorancia, que ha costado lo que en las anuas pasadas se ha escrito, y se dispuso la materia para que quando viniesse el ministro de $\mathrm{Su}$ Magestad no la hallase tan indigesta, sino quebradas muchas lanzas como él mismo dixo, en la audiencia de Chuquisaca antes de venir acá... El señor Visitador va gratísimo atribuyendo por su humildad la principal parte deste suscesso a la Compañía a la qual a favorecido $\mathrm{y}$ honrado en todo quanto se ha ofrecido de que havía mucho que decir, y él solo la deja mas favorecida y ayudada en lo temporal que lo pudieran hazer todos los que la han perseguido $y$ asssentadas las misiones $y$ reducciones y amparo de los indios que están a nuestro cargo $\mathrm{Y}$ dado traza en el sustento de los nuestros que están en las missiones como lo pudiéramos desear. En estos quatro años con la comunicación de los nuestros algunas personas doctas y de autoridad se han enterado de esta verdad y la han favorecido por palabra y escritos principalmente un Padre de S. Augustín, devotíssimo de la compañía, muy docto que ha leydo theología en essa Ciudad de Roma y en otras partes y muy hijo de V.P. que grave y doctamente ha hecho un tratado sobre esto del servicio personal aunque en breve, prometiendo hazerlo larga y copiosamente quando las ocupaciones le dieren lugar. Ya entiendo lo ha comenzado y será de gran gloria de Dios Nuestro Señor, bien de los indios y descargo de las conciencias de los españoles con lo qual él podrá ser de grande ayuda porra extinguir y acabar esta pestilencia del servicio personal... Otra particularidad muy principal parece haver sido la elección de la persona de quien había de visitar esta governación y quitar el servicio personal... parece cosa misteriosa lo que en esto ha passado, porque haviéndose gastado quatro años sobre esta determinación últimamente se vino a escoger la que más a propósito pareze havía en estos Reynos, y que los nuestros y otras personas zelosas mas deseaban por su grande experiencia, zelo y letras, y affecto extraordinario a los indios, cunque el hizo artas diligencias para reusar la carrera y no admitir este si:sio, como la determinación debió de ser del cielo, no la pudo escusar. Luego entrando en esta governación comenzó $\alpha$ desagraviar $\alpha$ los indios, y ponerics en libertad, y dentro de un año visitó entrambas governaciones, tássó el tr:buto que havían de pagar los indios y les puso ordenanzas y remedió los abusos que havía, siendo negocio que otro diligente ministro gastara en el mas de dos o tres años... Al tiempo que entró el Señor Visitador en Santíago del Estero desta governación, llegó acaso el mismo día un sacerdote de los nuestros letor de artes desta casa (Córdoba) muy inteligente en esta materia con quatro hermanos que se yban a ordenar con el Señor Obispo de aquella Ciudad... Y a petición del Señor Visitador predicó y apoyó el Padre la razón de su venida e injusticia del servicio personal y el Señor Obispo 
hizo lo mismo que fué de grande importancia para el buen principio que tubo este negocio y también lo fué el hallarse los nuestros con otros religiosos y personas doctas en las juntas que en esta ciudad se hicieron por orden del mismo Señor Visitador, y yo me encontré luego con él saliendo de Chíle y después en Santa fee, subiendo él con el governador a la Assumpción a visitar aquella provincia y fué fuerza hallarme con $\mathrm{mi}$ compañero y otros de la Compañía en las juntas y consultas que hacían con los religiosos y las demás personas doctas de aquella tierra sobre la justificación de su comissión, y aunque no volví con él concurrimos en Santiago del Estero, cabeza de esta governación adonde también por orden de Su Magestad hizo la principal consulta y junta con el Señor Obispo, governadores passado y presente, superiores de las religiones, letrados juristas, y procuradores de las ciudades y todos convenimos assi en esta junta como en las demas que el servicio personal destas governaciones havía sido injustíssimo, contra todo derecho, introducido contra voluntad de los Reyes chatólicos y contra sus cédulas; como también en poner tributos sobre las mugeres y niños y viejos, $y$ el Señor Obispo en particular en los sermones que hizo y juntas en que se halló procedió con zelo apostólico y al fin todos han convenido en estas dos governaciones en que lo que predicábamos y persuadíamos era justíssimo, y muchos nos la han ganado en el fervor y valor con que han defendido lo mesmo, aunque no en el padecer, porque ha querido Nuestro Señor por su bondad darnos en esto los mejores vocados a los de la Compañía si bien es verdad que el Señor Obispo ha padecido y padece mas de lo que se puede decir sin gronde sentimiento.

Los buenos effectos que deste negocio que con tanto fervor ha apoyado la Compañía se le han seguido... han sido: lo $1^{\circ}$ el descargo de nuestra consciencia procurando dar luz a los que tenían falta della, y en tanto provecho de su salvación. (2\%) haver restaurado la mucha reputación que huviera perdido si el Señor Visitador nos huviera hallado culpados in eadem damnatione, viéndonos con servicio personal, o por lo menos que lo tolerábamos en los que lo teníon y passábamos por ello sin cadvertírselo y predicárselo, y confessando a los que estaban en tan grande cargo de consciencia dejando de volver por gente tan desamparada: de todo lo qual ha notado otras personas y sentídolo cordialmente: $3^{\circ}$ hase alcanzado grande reputación y concepto con todos los indios asi fieles como infieles destas tres governaciones de que les somos únicos y verdaderos protectores y padres y asi andan los nuestros entre los infieles con summa seguridad y ellos y los xpanos acuden a los nuestros con todas sus necesidades espirituales $\mathrm{y}$ temporales con summa confianza y nos dicen a menudo lo que hemos padecido $y$ padecemos por ellos. $4^{\circ}$ havémonos librado de la culpa que los mesmos interesados aora nos pudieran poner, aunque no dejan de apuntarlo por lo passado, que como los de la Compañía no les havemos dado este desengaño antes de aora, que les huviera estado muy bien para lo espiritual y temporal. $5^{\circ}$ havemos experimentado en estas persecusiones y contradicciones, que como generalmente por una parte los interesados nos quitaban las cortas limosnas que nos solían dar y procuraban que nadie nos las hiciesse, ni aun nos vendiessen lo necescrio para nuestro sustanto: Dios Nuestro Señor por otra parte qui est dives in misericordia, nos ha probeydo de lo necessario en todas partes y mucho mejor que antes lo teníamos, sin que nos haya faltado cosa de momento, en que han concurrido muchas circunstancias mas mara. villosas que naturales que por brevedad no las refiero. Al fin. antes se sustentaban en estas dos governaciones diez o doce de los nuestros con su trabajo y aora nos sustentamos sesenta... y se han edificado casas e iglesias: 
y las dos fundaciones deste collegio y el de la Ássumpción están ya en víspera de comenzarse a gozar, que con la hacienda de todas las governaciones no se pudieran hacer $y$ al Rey Nuestro Señor proponen sus ministros de la importancia que es la Compañía en estas partes para su servicio y la obligación que tiene de sustentarle; y en Santiago del Estero, cuya casa despoblamos con gusto de los vecinos $\mathrm{y}$ aun procurándolo ellos y adonde la Compañía ha padecido la mayor persecusión por el servicio personal, ha ordenado Nuestro Señor que allí aya sido adonde principalmente con aplauso y parecer de tantos personajes $\mathrm{y}$ hombres doctos, se ha hecho justicia dél $\mathrm{y}$ a los de la Compañía insta el Rey, Virrey, Visitador, Governador y Sr. Obispo y entrambos cabildos a que vuelba, dándonos casa y sustento perpetuo para seis o ocho de la Compañía como a la larga escrivo a V.P. Y antes nj havía sustento, ni casa, ni iglesia, ni esperanza de poderlo tener jamás en que resplandece bien la paternal providencia que el Señor tiene con la Compañía". 


\section{Parecer de los Padres de la Compañía de Lima sobre las Orde- namzas dadas por el Visitador D Francisco da Alfaro, 1613.}

"El P. Juan Romero pregunta si están en buena conciencia y se pueden absolver los vecinos de Tucumán que no obedecen a las ordenanzas de D. Francisco de Alfaro, acerca de la reformación de la tassa de los Indios, y porque la respuesta se sacara claramente de la noticia del echo:

Digo lo $1^{\circ}$ que en aquella Governación avía una tassa por Gonzalo de Abrego, Governador que fué de aquella provincia, que toda la tassa servicio personal y que principalmente cargaba sobre las mujeres, como della parece. Y no se trata aquí de los excesos que avía en guardar essa tassa, por no ser esso importante al punto presente.

Lo $2^{\circ}$, acerca desta tassa se han de advertir 2 cosas: la $1^{\circ}$, acerca del poder de quien la hizo; la $2^{\circ}$, acerca de su justicia. En quanto a lo $1^{\circ}$, los Governadores por razón de su oficio no pueden tassar los indios; y el tassar pertenece al Oídor Visitador de la Audiencia, conforme á las ordenanzas della. Tampoco parece que Gonzalo de Abrego tuviese poder, ni comission, ni orden de S.M. para hacer tassa, ni hasta oy esta aprovada tal tassa por Consejo, ni Audiencia, ni Superior.

Lo $3^{\circ}$, en quanto la justicia della se puede considerar, que en el preludio da a entender Gonzalo de Abrego que ordena aquella tassa, en la forma que por ella parece, porque los vecinos no apellen ni sepan la causa; y al fin dá a entender, que quiso quitar algunas extorsiones y de los males que huviese menos, de suerte que collige, que conoció la iniquidad de la tassa.

Lo 4․, se ha de advertir que, por Cédulas Reales, está prohibido tassar Indios en servicio personal.

Lo $5^{\circ}$, se ha de advertir, que hombres muy doctos de todas Religiones, por pareceres firmados con nombres de Religión, Prelados y Lectores della, han declarado por injusto y contra consciencia al servicio personal que se usaba en Tucumán.

Lo 67, Aviendo ydo el Sr. D. Francisco de Alfaro á visitar aquellas Provincias, hizo algunas juntas para tratar este punto, $\mathrm{y}$ aviéndolo comunicado y conferido diferentes vezes, remitido la resolución para la conclusión deste punto. Y assi propuso era lícito el servicio personal en la forma que estava ordenado por Gonzalo de Abrego; $y$ en esta junta se hallaron juntamente con el dicho Sr. Oídor, el Sr. Obispo, el Governador presente y pasado; de la Catedral, un Prebendado; dos Prelados de las Religiones de aquella ciudad y sus Provinciales, que son: Custodio del Sr. S. Francisco, Provincial de la Compañía y Provincial de La Merced, todos los Theólogos y Juristas que se pudieron hallar en el Pueblo, 4 Diputados nombrados por los Procuradores de las Ciudades de la Provincia. Y aunque no tuvieron voto para decidir los Procuradores ni sus Abogados, ninguno se atrevió a decir afirmativa. mente que era lícito el servicio personal contenido y en la forma que lo disponía la tassa de Gonzalo de Abrego. 
Lo 79, se advierte, que el Consejo, por differentes zédulas ha mandado ó la Audiencia de Charcas que embíe ó visitar la Provincia de Tucumán, para que cessen los agravios que ailí reciven los Indios. Y últimamente embió zédula expresa con palabras muy apretadas para que se hiziese la dicha visita y tassa por el Sr. Licenciado Al Maldonado de Torres, y por su impedimento ó excusa el Oídor y Fiscal que nombrase el dicho Sr. Presidente de la Audiencia, el qual nombró al dicho Sr. D. Francisco de Alfaro; y entre othas palabras dize la zédula: "Y aviéndose enterado de los agravios y malos tratamientos que reciben los dichos Indios de sus Encomenderos y otras personas, los desagrabiéis $\mathrm{Y}$ pongáis en libertad. Y si no estubieren echas las tacssas de los tributos que hubieren de pagar á sus Encomenderos, y en caso que lo estén veréis aquellas tassas, y si fueren exesivas, las haréis de nuevo con la justificación y consideración que combiene, respecto de la calidad y sustancia de la tierra y de los naturales della, y de lo que pagan en otras partes desas Provincias del Perú; de manera que ellos ni sus Encomenderos no reciban agrabio". Después manda la zédula, que embíe relación el Visitador de lo que conbiene probeer en otras materias, y luego dize: "Y mando á mis Governadores de las dichas Provincias de Tucumán y Paraguay y otras qualesquier mis justicias que os assistan y den todo el favor y ayuda necesaria que les pidiéredes y hubiéredes menester para lo susodicho. Y que ellos y qualesquier otras personas vecinas y avitantes en las dichas Provincias, guarden, cumplan y executen lo que proveieredes $y$ ordenaredes para cumplimiento $\mathrm{y}$ execución de lo susodicho". Y pone pena a quien contraviniere.

Lo $8^{\circ}$, Aviendo el dicho Sr. Oydor echo la visíta de toda la Provincia, y muchas juntas, hizo la tassa y ordenanzas de materia de Indios. Antes de publicarlas las embió al Sr. Obispo, Governadores y Reliyiones, y todos se las aprobaron. Después de lo cual las embió á que las viessen los Procuradores de las Ciudades de la Provincia sin que faltasse de ninguna, y el Cabilcio de Santiago. Y aviéndolas visto, advirtieron algunas cosas que les parecía les combenía. Con lo qual, el dicho Sr. Visitador alteró algo, no muy considerable que le pareció podía concederse, y con esto firmó y despachó la tassa y ordenanzas, mandando que desde luego se executassen. Embiólas al Governador, Procuradores de las Ciudades y Cabildo de Santiago, que es la cabeza, para que lo cumpliesen. Apellaron y sin embargo, mandó executar. Pidieron los interesados que se notificasen $\alpha$ los Indios y se hiziesse saver. Hizose assi. Con esto fué saliendo de la Provincia, poniendo en execución en quanto se offrecía las dichas Ordenanzas. Los Procuradores de la Provincia y de las Ciudades embiaron Procuradores á la Audiencia en segui miento de su apellación. Tardaron cinco messes en verse las Ordenanzas una á una y informar en público y en secreto lo que pareció convenir. Después de todo lo qual, la Audiencia probeió auto, declorándose por no Juez; remitieron la causa al Consejo, y mandó que en el entretanto que S.M. y su Consejo otra cosa no probeia, se guardase lo que mandó el dicho Sr. Visitador. Suplicaron los Procuradores. Corfirmóse en revista.

Respondemos; que ay obligación so pena de pecado mortal, de guar. dar las Ordenanzas del Sr. D. Francisco de Alfaro, por estar echas y promulgadas con authoridad legítima de competente Superior y en favor del derecho natural y divino, contra quien es el servicio personal, que tan contra justicia se ha exercitado en Tucumán. Ni obsta la apellación que han interpuesto los vezinos de aquella tierra, por ser sin fundamento y estar mandado por la Real Audiencia de Chuquizaca, y confirmado en revista que se guaraen las susodichas Ordenanzas mientras no se revocan por el Consejo. Y 
es tan evidente y cierto que es pérfida y abominable cossa el tyrónico servi. cio personal, que tan impíamente se ussa en Tucumán, que sería manifiesta impertinencia ponerse á probar cossa tan clara, en especial siendo deste parezer todos los Theólogos desta Ciudad, con quienes en otras ocassiones se ha tratado este casso y convenido todos en lo que aquí dezimos. Y como las Ordenanzas susodichas sean en razón de arrancar tan nefando abuso, y echas por persona competente, y mandadas guardar por Tribunal legítimo, no obstante qualquiera apellación; es llano averse de estar á lo assi mandado, aun quando fuera dudosa la justificación de las Ordenanzas, avía obligación de cumplir con ellas; pues in dubiis parendum est superiori praecipienti, como resuelven todos los theólogos con Santo Tomás, en la materia de conciencia dubía. Esto nos parece.-Lima, último de Agosto de 1613.- Juan Sebastión - Francisco Coello - Francisco de Contreras - Juan de Perlin - Diego de Torres - Juan Romero - Francisco Vásquez - Diego Gonzalez - Francisco Vósquez de la Mota - Juan Pastor - Gaspar de Monrroy - Juan de Viana - Juan Baptista Ferrussino - Marco Antonio de Otaro - José Cataldino Lope de Mendoza - Mateo de Montes". (1).

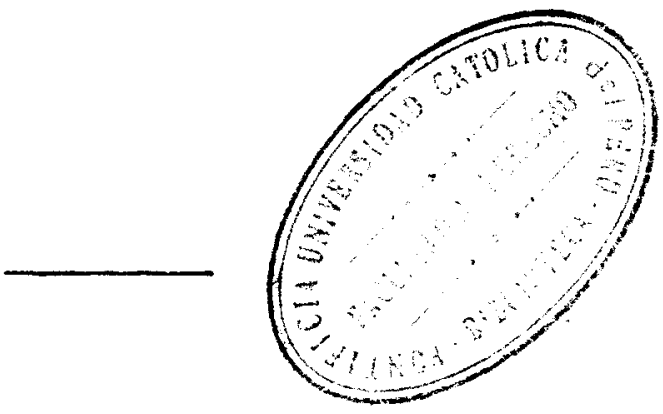

(1) Algunos de los PP. que firman esta copia no perteneciar a la Provincia del Perú sino $\alpha$ la del Paraguay, pero como el parecer se había dado en favor de estos indios, la sus cribieron para mayor autoridad. 


\section{Parecer del P. Pedro de Oñate sobre las Minas de Huancarelica 1629 .}

\section{Cuatro questiones que se propusieron e n ruestro Colegio de Lima.}

$1^{\circ}$ - Si puede el Virrey compeller a los Indios a que labren las minas de Huancavelica (como oy lo haze) supuestas las muertes y asolación de aquella Provincia que se le sigue.

$2^{\circ}-$ Si podrá dar nuevos indios el Virrey de nuevas Provincias para que suplan por los que se han muerto.

3c-Qué grado de servidumbre tiene que no los puede dar y si lo podrá absolver su confesor.

4-Si estó obligado a avisar al Rey, primero, que los quite y lo que debe hazerse en el interín para el remedio de los daños y muertes de los indios.

\section{Guancavelica.}

Q. $1^{\alpha} \mathrm{Si}$ es justo compeller a los indios a que labren las minas de

Por fin de Agosto de 1629 se comenzó a tratar por parte del Virrey si podría lícitamente repartir de nuevas provincias indios a Guancavelica a cumplimiento de los 2,000 que se solían dar, porque las Provincias que los daban no los podían cumplir por estar ya asoladas con las mismas mitas de Guancavelica. Propúsenos el caso en la manera siguiente por parte del Vjrrey. (El Conde de Chinchón).

En este caso, como se pregunta, no se propone formalmente la duda de si los indios de Guancavelica que se han dado y dan son lícitamente compellidos a aquella mita o no, pero es necesaria la solución desta questión para venir a estotra y para entender toda esta materia y asi la trató en primer lugar.

Y para entender todo lo que hemos de tratar es menester suponer lo $1^{\circ}$ que es común voz del Reyno y clamor de los mismos indios y de sus curas que las dichas minas de azogue han sido sepultura y muerte de aquella Provincia y que la tienen asolada y la misma proposición del caso la presupone asi, porque del resulta que de las Provincias de que antes repar. tieron los Virreyes, 3,280 D. Francisco de Toledo y el Conde del Villar 3,665, ahora no ay 2,000 indios que son los que repartieron en el $6^{\circ}$ asiento, pues para enterar este nuevo propone el Virrey como necesario aver de repartir a nuevas provincias. Y lo cierto y averiguado es, y como tal lo supongo en este caso, que el día de oy no pueden ir de las dichas provincias más de 600 indios efectivos. De lo qual evidentemente se colige que se han consumido desde el tiempo del Conde del Villar, que repartió 3,600, acá tres veces 7,000 indios que son 21,000 de 25,200 que entonces eran, que es lastimosa mortan- 
dad y en proporción se han consumido de 6 partes las cinco de los indios que solía aver. Y cunque algunos deseosos e interesados destas minas se procuran evadir diciendo que también en otras provincias donde no ay minas de azogue los indios se van menoscabando y que muchos de los que faltan en Guancavelica son huidos, respondo que los que en otras provincias faltan son muy pocos respecto deste número y que los que huyen van huyendo de la muerte y no justifican la causa del Rey, sino antes arguyen ser los agravios intolerables y que en las mismas enfermedades de que mue. ren, que es azogados y de aquella tosecilla que les dá se hecha de ver que les mata el azogue. Así que en el caso se supone que las minas de azogue de Guancavelica ut jacent han sido la causa de la muerte de los indios $\mathrm{v}$ destruición de aquella Provincia y que esto lo muestra la experiencia clara y notoria y confesada por la parte que es el Virrey.

Lo $2^{\circ}$ supongo que S.M. tiene mandado loydas estas muertes y asolación destos indios) que se procure que vengan de su voluntad a labrar estas minas, edificando ciudades junto $\alpha$ ellas $\mathrm{y}$ haziéndoles $\alpha$ los indios que las labraren comodidades y concediéndoles privilegios \& pero si desta manera no pudieren ser atendidos que les compelan y desta compulsión y fuerza que se les haze es toda la duda.

Lo $3^{\circ}$ supongo que de tres maneras se pudiera entender $\mathrm{y}$ disputar si esto es ilícito. Primero, por ser contra el derecho del Reyno; segundo, por ser contra el derecho común; terlero, por ser contra el derecho natural. $Y$ en cuanto al derecho del Reyno no ha aquí lugar la cuestión, porque esta cédula y ordenanza de S.M. que manda sean compelidos los indios a estas minas es ley y derecho del Reyno y, lo segundo, porque el Rey que es el que manda esto, es sobre todo el derecho del Reyno y asi aunque huviera algunas leyes antiguas que mandaran que nadie fuese compelido a labrar minas o estas minas en particular, no podía hazer ilícita esta labor por vigor desta última cédula.

Lo $4^{\circ}$ supongo que el compeler indios u otro cualquier género de gente a labrar minas es clara y expresamente contra el derecho común civil, porque está todo el título de poenis \& lleno de leyes porque se veda ser compelidos los hombres libres a labrar minas, declarando que es tan grave pena damratio ad metalla infligi non debet sino por atroces delictos, porque es pena capital e induze muerte civil y induze también cierto modo de servidumbre, con lo qual damnati ad metalla dicebant servi y era mayor que la pena de deportación ad insulas \& y al fin quando los Reyes o Emperadores querían atormentar mucho a los mártires y que muriesen mala muerte los he. chavan a las minas y así vemos muchos mártires, celebrados de la Iglesia por tales, porque murieron condenados a las minas, luego es tan gran trabajo que equivale a muerte y tan terrible que se dava por cruel género de martirio. Y asi no se lee de ningún Rey que haya compelido a hombres libres a labrar minas de metal sino por vía de pena de delictos gravísimos y capitales 0 a esclavos avidos en guerra o de otra manera.

Lo $5^{\circ}$ supongo que esto no haze al caso para condenar la ley de que hablamos, porque los Reyes de España, como es notorio, y tienen todos los autores no están obligados a guardar el derecho común y asi aunque él tenga vedado hechar hombres libres a minas los pudieran hechar los Reyes de España no siendo contra el derecho natural que es lo que ahora está por averiguar. 
Art. 2:-Si es contra el derecho natural.

Que no lo sea se puede probar, lo $1^{\circ}$ Porque estos indios son de naturaleza servil, luego deben ser tratados como siervos y a los siervos les pueden los Reyes y cualquier particular cuyos sean compeler a que les labren minas, aunque sean de azogue, luego a estos indios. $2^{\circ}$ Conocida cosa es que los indios son holgazanes $\mathrm{y}$ haraganes y que si les dejan a su albedrío nunca se ocuparán en nada de provecho de la república y al buen gobierno de las repúblicas compete que los Reyes y jueces no sufran ociosidad que es madre de todos los vicios y compelan a trabajar a los holgazanes y vaga bundos, Juego conviene por leyes echar a estos indios a que trabajen en las minas. $3^{\circ}$ Esta ociosidad favorece, mucho y es causa de las borracheras destos indios que es vicio infame y torpísimo a que son muy dados, luego conviene quitárselo y trabajarlos. $4^{\circ}$-Sin azogue no se puede labrar la plata y thesoro que se embía cada año a S.M. Y sin este tesoro no se puede acudir a las querras contra los herejes y de la fe católica que haze el Rey de España que es oy el principal y más fuerte brazo de la fee. luego para que se conserve la fee y se destruyan las herejías y para todas esas guerras de Flandes y Alemania es menester hechar los indios por fuerza a las minas, porque sino no se labraran. $5^{\circ}-$ La potencia y monarchia de España no se puede oy en día conservar sin este thesoro que va de las Indias, porque es el mayor que tiene el Rey y que ha tenido jamás Rey desde Salomón acá, luego para que se conserven los Reynos de España en esta pujanza y prosperidad es menester que estas minas se labren y saque esta pata. $6^{\circ}$-El mismo reyno del Perú no se puede conservar sin estas minas de Potosí y las dernós de plata porque son el cebo que ha traydo acá los españoles sin los quales estos reynos ni tuvieran fee ni doctrina ni policía y luego fueran invadidos y conquistados de los enemigos y las demás minas no se pueden labrar sin azogue ni el sin compeler los indios de Guancavelica a sacarle. $\mathrm{Y}$ estos argumentos tienen más fuerza porque todos o los más dellos pareze se dan por razon en las cédulas reales que mandan sirvan estos indios en las minas de Guancavelica, aunque sea contra su voluntad.

Esta questión es la principal y fundamental desta materia y para proceder con claridad en ella supongo que aquí se pueden tratar 3 questiones diferentes: una es si es lícito obligar a los indios a que trabajen en las minas sean de plata, cobre o azogue sino asi en común: $2^{\alpha}-\mathrm{Si} \alpha$ minas cualesquiero que sean; $3^{a-S i}$ a estas de Guancavelica, por su especial qualidad, esfecialmente labradas por el socavón, como aora se labran. Porque, cunque se siga bien no se pueden labrar minas ningunas compeliendo los indios, luego ni las de Guancavelica, pero no se sigue, al contrario, puédense labrar las minas de Potosí \& con apremio de los indios, luego las de Guancavelica. No se sigue, porque son sin comparación mucho peores y de maligna qualidad. Y otros tormbién pretenden que aunçue no se pueda labrar el socavón se puede labrar las minas de azogue, como el P. Menacho y el P. Agia que sintieron poderse labrar minas de azogue pero no las del socavón.

Pero esta diferencia yo no la tengo por probable, porque aunque confieso que el socavón debe ser más dañoso a la salud y vidas de los inclios, pero lo principal de aquel daño entiendo se sigue de labrarse minas de azogue como quiera que sea. Por que bien se sabe $y$ ve a vista de ojos cuan terribles son los efectos del azogue y quan dañosos a la salud y vida, pizes de sólo desazogar piñas y pisar los caxones en que se repasa el metal de la plata se azogan muchos y pues vemos tales efectos del en los que toman 
las unciones y asi S.M. mandó los años pasados que estas minas no se labrasen sino a tajo abierto. Por lo qual entiendo que los que han condenado el socabón y aprobado las demás labores sólo tuvieron intento de dezír que las que se pudiesen labrar sin riesgo de la vida, lo qual juzgo por moralmente imposible en minas de azogue no labradas a tajo abierto. Es pues nuestra questión si puede el Rey con buena conciencia hechar los indios a las minas de azogue de Guancavelica.

También hemos de suponer en el hecho que los indios repartidos a las minas son la $4^{\alpha}$ parte de los de aquella provincia, aunque antes eran la $7^{\text {a }}$ y no están repartidos sino para que trabajen 40 días y luego descansen hasta que les buelva otra vez la mita que viene a ser puntualmenie cada año una vez por un mismo tiempo.

Esto supuesto digo que de dos maneras se puede entender que el Rey tenga potestid para hechar indios o otra cualquier suerte de gentes a minas.

Lo l:-Por vía de tributo ordinario para que le paguen el que le deben como sus vasallos en servirle en las minas, como los españoles pecheros se lo pagan en plator o otras especies o como los demás incios se lo pagan en las mitas. Lo 2 - - Por vía de extraordinaria y urgente necesidad que ocurre a la repúblicci y reyno de que los dichos indios acudan a aquellas minas para que aquella necesidad se remedie. Al modo que un Rey aunque no pueda imponer necesidad a sus vasallos por vía de tributo ordinario que bayan a la guerra, pero si el enemigo acomete y está la república en peligro podrá quitar los soldados y hazer que toda la gente acuda y lleve carga personalmente para ieparar un muro o hazer un castillo y pasada aquella ton precisa y urgente necesidad no tendría el Rey potestad para hazerles trabajar de aquella manera. Y destos dos modos aunque ambos se impugnarán, pero el primero es el que se pretende $y$ el que solo puede tener lugar en este caso. Lo primero, porque el $2^{\circ}$ modo nunca es perpetuo sino por gravísima e incidente necesidad de la república, que rarísimas veces acontece. Lo 2.-Porque no ay ni ocurre ahora ton urgente necesidad de la vida de nadie para que las vidas de los indios se hayan de poner a peligro.

Pruebo pues lo $1^{\circ}$ y sea la primera conclusión que por vía de ordinario tributo que estos indios le deban a S.M. no los puede compeler a las dichas minas. Para lo qual es menester suponer los principios de la materia de tributos tomados de todos los autores que de ellos escriben. De los legistas, $\$$ de Censibus, lib. 10, de los canonistas, $\$$ de vectigalibus, de los Sumistas, verbo tributum et verbo gabella et verbo vectigal (Lessio. lib. 2, c. 33 de Tributis et Vectigalibus. Covar. reg. peccatum p. 2, No 5. Molina. Disq. 661 $N^{\circ} 2$ de cust. reginal. Cayst. in sum. verb vectigal et gabella. 3. quod tributum est pensia qua subditis solvenda imponitur juxta cujusque facultates praesertim praediales ad principis dignitatem et communia impendia sustinenda. Vectigalia vero pro exportandis vel importandis in civitate ut quas soivuntur in portibus vel in confiniis regnorum. Es pues el tributo el justo salaric que el reyno le dá al Rey con que le paga el officio de Rey que con el haze y le da todo lo que es menester para el gasto que en su oficio ha de hazer en bien y provecho del Reyno, que tiene tres partidas principales, lo que ha menester para el sustento de su persona real con la authoridad y majestad de aquel supremo oficio, para administrar justicia en todo su Reyno y pagar los salarios de los ministros della y para defender la república de sus enemigos y tenerla suficientemente armada y pertrechada contra ellos y para tener los caminos y puentes \& bien acomodados y todo lo demós que es necesario para el bien de la república. De manera que es como el salario que se dá al oficial, carpintero o sastre, quando el ha de poner no solo su 
trabajo e industria en hazer una obra de su oficio sino también los materiales como la madera o paño y seda \& asi porque el Rey ha de poner no sola su trabajo y industria sino también los gastos en la administración de su oficio pagando a los ministros de justicia y a los soldados, el Reyno le ha de dar lo necesario para ello y lo que fuere necesario para esto y no más y conmensurado y ajustado con estos fines podrá el Rey llevar por vía de justo tributo y no otra cosa ninguna.

De aquí es que los Doctores tratándo del tributo piden 5 condiciones para que sea justo, especialmente Cayetano y Lessio en los lugares citados. $1^{x}-$ De parte del que impone el tributo que sea persona que le pueda imponer que son todos y solos los que tienen soberana autoridad y no reconocen superioi en lo temporal. $2^{\text {a }}$-De parte del fin que se imponga cosas necesarias del Reyno y a su bien común como queda declarado. $3^{a}-$ De parte de la persona que sea la quantidad moderada y conmensurada, id est, la que es necesaria $y$ ajustada con los dichos fines y no más, porque no grave el reyno con los tributos no necesarios y que esta quantidad necesaria á conveniente para aquellos fines sea repartida igualmente y con debida proporción entre los miembros de la república de tal modo que no les quepa mas $\alpha$ los pobres que a los ricos sino menos y a los que no son mexcaderes que a los que lo son sino menos. (Sessio 5. núm. 6 ne pauperes graventur pro divitibus et qui mercatores non sunt pro mercatoribus \&). $4^{\alpha}-$ De parte de la materia que sea impuesto en las cosas que menos gravan a los súbditos y no necesarias a la vida, como dize Lessio \& 5 - Ex usu quando insumunt in causam publicam pro qua juste sunt instituta et non prorrogant ultrc necessitatem neque in largitionibus profusis et vanis (1).

De que colijo que si estas 4 condiciones se verificaren en el tributo presente de hechar los indios a Guancavelica será justo hecharlos y si no no será justo.

Pue: esto supuesto, respondo a este caso que de suyo hechor a los indios a las minas de Guancavelica es ilícito y injusto. Lo qual pruebo con tales razones que in re morali son grandísimas evidencias. Porque faltan casi iodas las condiciones para que el tributo sea justo. Confieso que no falta la primera que es el imponente justo y legítimo, pues el Rey que es el que les obliga a ello es la persona que les puede imponer tributo. Pero de esta primera condición hemos de sacar de camino que el Virrey no puede meter en este tributo nuevas provincias, porque es imponer nuevo tributo que no lo puede hazer y está descomulgado por la Bula de la Cena el que no teniendo facultad y potestad para poner tributos nuevos los impone, antes tiene prohibición expresa del Rey para que no meta nuevas provincias a pagar tributo.

El fin debido falta en este tributo sin duda ninguna, suponiendo que no es remediar la necesidad de este reyno ni los reynos de España sino te-

( 1) Por parte del uso, cuando se emplean en beneficio de la causa pública para lo cual fueron instituidos $\mathrm{y}$ no se prorrogan sin necesidad o invierten en larguezas inútiles $\mathrm{y}$ vanas.

(Al margen). Lessio tratando más en particular lo que requiere el tributo ex parte formae pone 4 condiciones ex Cajetano verb. vectigal et Petro Navarro lib. 3, de vectigal. c.1.n. 255, la $1^{a}$ ut constet saltem probabiliter eam esse justam; la $2^{\alpha}$ ut causa sit vectigali proportionata; $3^{9}$ ne insumat in alienos usus, ut in prodigas largitiones et alias expensas inutiles publicas vel privatas; $4^{q}$ ne diutius quam causae postulent continuent. Vide Castrum, De Lege poenal. lib. 1, c. 11-Tolet. lib. 5, sum. c. 73 ubi dicit esse excomunicatos qui prohibita poedargia exigunt. Angelum, verb. poedag - Vict. Relect. 4 De Jure Belli. 
ner que defender la fe en los reynos extraños y para sustentar las guerras de Flandes y Alemania. Porque aunque este fin es santísimo y piísimo pero no es el que puede justificar los tributos. Pero estos no los justifica la necesidad de los reynos extraños y de la Iglesia Universal sino la necesidad de conservar la fee y paz y mantener justicia en los propios reynos. Porque no está obiigado el Rey de España a cacudir a todas las necesidades de la Iglesia ni puede, imponiendo tributos para acudir a ellas ni las r₹públicas y reynos de España están obligadas a dar tales tributos, porque aunque sea bueno este fin no es respecto destas personas de obligación sino de supererogación ni de precepto sino de piedad $\mathrm{y}$ equidad $\mathrm{y}$ los tributos han de ser impuestos para las cosas necesarias o convenientes de los mismos reynos en que los pagan no de oíros extraños. Si al Rey de sus tributos justos y thesoros le sobrara con que hazer tales guerras a los herejes y ayudar a los cathólicos y a la Iglesia fuera justo y santo pero para ese fin poner tributo y tal tributo no lo es ni puede ser (1). Porque ni se contiene en los límites de los justos tributos ni ay la santa y presumpta voluntad de las repúblicas que los pagan para que sea justo hazerles contribuir por fuerza a tributo tan voluntario y fuera de su obligación. Y vése claramente ser esto asi, porque si este tributo para estas guerras de la Iglesia y contra herejes y bien de la fee cathólica se pudiera imponer justamente, pertenecía al Papa a quien incumben estos fines poner este tributo temporal en orden a lo espiritual que al Reyno de España y ninguno dijo ni soñó jamós que el Papa pudiese pedir tal tributo, luego ni el Rey para este fin espiritual del bien de la fee y extirpación de las herejías. Luego aunque sacar esta plata para estos fines y para sacar la plata sacar el azogue sea necesario no podrá imponerse tributo para eilos. Como si esta república deba contribuir para los gastos destos reynos no para la contribución de los extraños. Y si este Colegio ha de contribuir para los gastos que haze el Rector en el o el Provincial no empero para los gastos propios de otro Colegio. Ántes tengo por cierto que supuesto que el Rey de España tiene tantos reynos debajo de su corona, aun los mismos reynos de España no están obligados a contribuir los unos para los gastos de los otros. Porque qué obligación tiene España, v. gr. para contribuir pora los gastos de las Indias ni las Indias para contribuir para los indios de acá. Ni aunqua fuera necesario para el bien deste Reyno sino es necesario para el bien d $s$ la misma Provincia de Guancavelica entiendo no fuera lícito ex parte finis poner tal tribulo, pues no es para su bien sino para el ajeno y contra su voluntad no con tácito ni expreso consentimiento del que ha de pagar el tributo.

La forma deste tributo es la que falta más expresamente y más injusto le haze. Porque esta forma consiste en dos cosas en la debida quantidad conı el jornal o salario que se da para cualquier oficio y en la proporcional iguaidad guardada entre los contribuyentes y ambas faltan aquí enormemente. La $1^{\alpha}$ es quantidad excesiva y de inestimable precio la que a estos indios se les pide para este tributo. Porque qué razón pide que a los españoles más ricos y poderosos en España no se les pida de tributo y pecho más de valor de un peso y aun no $\mathrm{y}$ sean 2 o 4 y a estos se les pida cosa que vale más de 100 o 200 ps. si se huviera de apreciar a plata que es la obligación de ir $\alpha$ trabajar $\alpha$ tan peligrosas minas? (2). Si el justo tributo de las demás pro-

(1) Supónese que ir más plata a España es gran bien suyo, de lo qual muchos dudan. (Al margen).

(2) La primera injusticia es que este tributo es de excesivo precio, aunque no contuviera servicio personal ni quitara la libertad $\mathrm{y}$ vida. (Al margen). 
vincias, el de sus tasas, que pongamos sean 6 ps. como el de estos pobres indios es cosa de tan inestimable valor... en esta tierra no tiene precio?. Lo 2:-Lo pruebo. El tributo justo del Rey es la tasa y digamos también la mita que hazen los indios en otras provincias para las labranzas y crianzas, támbos \& Pues cómo puede ser justo que demás desto den estos indios el trabajo de las minas de Guancavelica cuya compulsión es de tan grande moral estima?. 3-Lo pruebo así: Si el Rey pidiendo a los demás indios 6 ps. de tasa les pidiera a estos 50 , sin duda todos dijéramos que era excesivo y desigual tributo y contra la ley natural, por que para que evidentemente sea contra eila basta la desigualdad en la quantidad y esta tengo yo por evidente demostración por vía del precio excesivo, como aunque mi bonate tenga algún valor por el cual se pueda comprar o vender es evidente que no vale $100 \mathrm{ps}$. O en el mismo género aunque el rey ponga pecho y tributo. justamente $\alpha$ los pecheros españoles es evidente que no les podría poner justamente de tributo 50 o 100 ps. cada año y esto todo procede cunque fuera el tributo en plata del mismo precio que es el trabajo de las minas y es aunque los súbditos vinieran en ello, porque el oficio del Rey no vale tanto respecto de cada uno dellos.

La $2^{a}$ injusticia es imponerse en servicio personal. Porque los Doctores dizen que el tributo no se ha de poner sobre las personas libres $\mathrm{y}$ ingenuas sino sobre las cosas y aun entre esas cosas dizen, como hemos visto, que no se puede imponer sobre las necesarias como sobre las menos necesarias y la razón es porque estos tributos impuestos sobre las personas las gravan mucho $Y$ impiden su libertad, luego cunque fuera lícito imponer tal tributo sobre las cosas, que valiera 50 ps. v. gr. no lo fuera hecharle sobre las mismas. personas, porque este es un género de servicio personal muy odioso y que grava mucho los vasallos (cuya libertad y ingenuidad está obligado a mirar mucho y conservar el Rey) que aunque no es servicio personal perpetuo en servicio personal por el tiempo que dura. Para lo qual es necesario entender que servicio personal sumptum pro jure es cualquier obligación que se ponga a la persona de que sirva a otra con sus acciones personales sin su consentimiento y aunque es verdad que como se toma en esta tierra y para que induzca verdadera servidumbre ha de ser perpetuo $y$ no pagado pero tanto más se llega a este perpetuo quanto más tiempo dura y 40 días cada año de minas sin lo que tarda en ir y venir no es poco máxime con los sumos gravámenes que después veremos. $Y$ aunque le pagan no como merecen pues a los mingas (1) les pagan más que tres doblado más y es justísimo de parte de los indios aquel contrato y todo aquello les quita el Rey del valor de su servicio con sus mitas por fácilitar la labor de las minas. De manera que aviendo de pagar de razón más a los que van forzados que a los que se alquilan de su voluntad, porque aquella voluntad es precio estimable, se les paga menos.

La $3^{a}$ injusticia es que no sólo es servicio personal dado por tributo sino servicio personal forzado de minas de metal, en lo qual considero el horror que ponían aun a los antiguos gentiles emperadores romanos las minas pues jamás hechavan a ellas a nadie sino a quien tenía tan atroces delictos que merecía pena capital y tal llamaron ellos al echar a las minas y era y es, sin duda, más dura pena que las galeras que no es pena capital entre nosotros. Y moría civilmente a quien se le daba et patiebatur dimidiam capitis diminutionem et induebat quoddam genus servitutis, de manera que por

(1) Mingas o mingados, indios de alquiler. 
tributo les da el Rey una cosa tan trabajosa y penal que era pena de muerte $y$ muerte civil y servidumbre $y$ mayor pena que la deportación in insulas, pues quien ha dicho jamás que tal cosa como esta se pueda pedir en justo tributo?. A los mártires a quien quería el pueblo romano atormentar más que con la misma muerte los hechavan a las minas y la Iglesia tiene a los tales mántires y nosotros christianos y píos martirizaremos con este género de martirio a los pobres indios?. Ponderó muy bien esto el P. Rebello diziendo: los crueles emperadores romanos, los más graves perseguidores que ha tenido la Iglesia inventaron este modo de crueldad para los mártires porque se convertían a nuestra santa fe y nosotros al tiempo que estos se convierten a ella les condenaremos a este mismo suplicio? (2). Lo $2^{\circ}$-Los moros quando un cautivo suyo reniega de Cristo y se vuelve a su ley le dan libertad y nosotros que avíamos de hazer lo mismo con los que a nuestra santa y verdadera fee se convierten al mismo tiempo que la reciben les ponemos esta moral servidumbre, servicio personal y capital pena y les condenamos a las minas?. Ideo male audimus apud exteras nationes. Porque parece que no hizo tanto Pharaon qui opprimebat populum Dei operibus luti el lateris, haziéndoles dar su jornal en adobes y poner la paja, pero qué tiene que ver hazer adobes con trabajar en las minas y socabón de Guancavelica?.

La $4^{\alpha}$ y más grave injusticia es que no sólo se les compelle a trabajar en minas sino también en minas de azogue con tanto peligro y riesgo de la vida que parece que lo mismo es contratarlos a ellas que condenarlos a muerte. $\mathrm{Y}$ está asolada la tierra como al principio propusimos. Pues quien jamás dijo que gente ninguna en el mundo deba pagar en tributo sus propias vidas. Pues desto concluyo mi razón así: La vida es de inestimable valor y precio, los que van a estas minas ponen a peligro sus vidas luego dan en tributo una cosa de inestimable precio. Luego no puede ser tributo justo pues excede el valor de lo que se puede deber por vía de tributo inestimablemente. 2 :-Los señores no pueden poner en peligro las vidas de sus esclavos... en servicio suyo, porque aunque sean sus dueños no lo son de sus vidas, luego mucho menos los Reyes. . . dominio en sus vasallos que los señores de los esclavos. $3^{\circ}$ -El Rey no es dueño y señor de las haziendás de sus súbditos, como es cierta y recibida opinión de los Doctores, luego no puede ponerlos a grave riesgo de sus vidas. 4'-Cualquiera obligación de restitución la excusa el evidente y manifiesto peligro de muerte, luego aunque la quantidad fuera mucho mayor cesa la obligación del. Finalmente la vida de un inocente es de tanta estima que ni para librarse del cerco una ciudad muy apretada con el, ni para librar la vida de toda una república es lícito entregor $\alpha$ un inocente $\alpha$ cierta muerte $y$ estos indios son inocentes e inculpados en quanto a no aver hecho agravio al Rey, luego no se pueden entregar a la muerte hechándoles $a$ estas minas donde se sabe moralmente hablando que han de morir pues en tan pocos años de seis partes se han consumido las cinco.

La $2^{a}$ condición de la forma de los tributos justos dezíamos que era la proporción o igualdad y esta también estó enormemente lesa en este tributo, parque si los españoles no pagan más de un peso de tributo a su Rey que haze más el oficio de Rey con ellos que con los indios, porqué los indios han de pagar tanto más? y si los demás indios pagan sus 4 ps. digamos, y la mita de los tambos $y$ las ciudades, porqué estos desventurados han de pa-

(2) No hemos podido comprobar si el P. Rebello pertenecía a la Compañía de Jesús. Hubo en el S. XVII un tranciscano, Fr. Francisco Rebelo, pero si el P. Oñate aludiera a este no habría dejado de indicar que era traile. 
gar la mita de minas y tales minas como las de Guancavelica?. Y si el Rey tiene necesidad de tapto thesoro para defender sus reynos a los ajenos y pasa la fee cathólica y destruir los herejes, por qué no se distribuye la contribución por todos igualmente de manera que, como dizen todos los authores, a los más ricos les quepa más y a los más pobres menos, sino tan al revés que a los españoles ricos no cabe nada y a los pobres muy poco y a los indios ordinarios mucho más y a los indios de las minas que revienten y a los de Guoncavelica que mueran mala muerte,. Luego en la distribución de los gastos no se guard́a la proporción debida y asi este tributo es injusto ex parte formae, asi porque se les echa más quantidad de tributo excesivamente que deben como porque la proporción no se guarda.

Pues ex parte matericue ya queda declarado cómo es injustísimo este tributo, porque aviéndose de imponer en las cosas se impone en las acciones libres y personales y aviéndose de poner en las cosas menos necesarias para la vida se pone en las más necesarias y en la misma vida.

Y la $5^{a}$ condición ex parte usus es queja universal que falta porque se sabe que hazen muchas liberalidades y gastos los Reyes de España que es cierto que se podríon y deberían excusar, salva regia liberalitate et magnificentia (1) y respecto destas minas se deberían excusar, porque aunque no sean ilícitos son empero muy voluntarios y no obligatorios y para tales gastos no puede tener color ninguno de verosimilitud hechar indios forzados $a$ que labren minas de azogue.

Art. $3^{\circ}$-Otras razones con que se prueba lo mismo.

$3^{\circ}$-Principalmente pruebo que es injusto este tributo. Ningún confesor avrá ni ha avido que si no van estos indios a las minas y pagan al Rey este tributo les obligue a restitución ni les absuelva de tal pecado y el no pagar tributo justo es de fee que es pecado. Reddite quae sunt Caesaris Caesari et quae sunt Dei Deo. (2). Et Reddite ergo omnibus debita, cui tributum, tributum, cui vectigal, vectigal \& (3) Y obliga a restitución como qualquier otro trabajo por justo salario, luego no es justo tributo (4).

(1) Sabido es que, a partir de Felipe III y mucho más en adelante, los gastos de la Casa Real eran exorbitantes $y$ que el derroche se acentuó en tiempo de los validos como el Duque de Lerma $\mathrm{y}$ el Conde Duque. Los despilfarros del Duque de Lerma, privado de Felipe III, acentuaron la decadencia económica. El Conde Duque trató de poner remedio $\mathrm{\gamma}$, al ascender al trono Felipe IV، aconsejó al Monarca algunas medidas a fin de contener el derroche de las rentas, pero sus ambiciosos planes de hegemonía política hicieron varos sus esfuerzos y el lujo reinante en la Corte no disminuyó sino antes bien subió de punto. V.E. Schafer. Apuntes sobre las dificultades financiercss de España durarte el Reinado de D. Felipe IV según los documentos del Consejo de Indias. (Investigarión y Progreso. Año IX. p. 276 Y s.)".

(2) Lucas. 20, 25.

(3) S. Paulus, Ad Romanos. 13. 7.

(4) (Al margen) La razón. Si fuera lícito compeller a los indios a las minas fuera lícito también compeller a los espainoles porque eadem est vel major ratio, sed hoc nullus unquam audebit affirmare $y$ si no lléguense a los españoles a decirles que labren ellos estas minas para la exaltación de la fee católica y destrucción de las herejías y verá si respingan. No ay duda sino que se levantorían contra el Rey y ninguno les tendría por obligados a tal, luego los indios solamente fadezen esta opresión por ser gente indefensa y pusilánime y desarmada que si ellos tuvieran brío, ni nosotros la hiziéramos ni ellos la padesieran. 
$4^{a}$ Razón ab authoritate porque authores impresos in terminis han condenado este género de tributo: el P. Rebello, el P. Joseph de Acosta, el P. Juan Pérez Menacho, Fr. Bartolomé de las Casas, Obispo de Chiapa y, podemos añadir, el Sr. Arzobispo Loayza, que se retractó al tiempo de la muerte y por la contraria opinión no se podrá citar autor ninguno que tales minas haya justificado. Antes me hace fuerza grandísima este argumento que de los principios inmediatos de todos quantos authores han escrito la materia de tributos se colige ser este pernicioso e injustísimo y hase de advertir que aunque S.M. y los de su Real Consejo tienen la opinión contraria, S. $M$. no es de creer que está bien informado de las muertes que pasan ni que tiene más parte en todo esto que remitirlo a su Real Consejo. Y los del son votos movidos de temor, apasionados y interesados, como también lo son acá los deste reyno, porque no osan decir cosa contra el interes de S.M. principalmente que también es suyo y en cosas ya eníabladas y esta pasión, interés y temor de ofender al Rey y reynos de acá y de España y que no se levante todo el mundo les ciega para que vean una verdad tan evidente y una injusticia tan enorme.

$5^{\alpha}$ Razón es que los authores en esta materia tienen que en estando en duda si el tributo es justo o no le deben los vasallos pagar y que en duda se presume el tributo injusto luego pues por lo menos ay duda de si este tributo es justo o no, no le deben pagar ni se debe imponer de nuevo ni cobrarse adelante.

$6^{\alpha}$ Razón que el Rey mismo es interesado en que no se lleven adelante estas minas como están porque si chora está tan rematada y asolada esa provincia, presto lo estará la que entrare de nuevo y luego la otra y otras que se fueran metiendo y asi en discurso de tiempo se ha de venir a tal asolamiento de indios y provincias que sea imposible del todo labrar minas y enton. ces perderó el Rey no solo el tributo del azogue sino también el de las personas de los indios y toda la plata que con ellas se saca y quedará reducido a imposibilidad el sacarle de ahí adelante.

Finalmente si estas muertes por alguna vía se pudieran justificar, avía de ser por ser del todo necesario labrar estas minas, luego si mostráremos no ser necesario sino que se pueden labrar las minas de azogue y sacar la cantidad necesaria para que labre toda la plata que ahora quedará del todo inexcusable el hechar los indios a estas minas.

\section{Art. 4-Cómo se podrá excusar hechar los indios forzados a las minas de Guancavelica.}

El $1^{\circ}$ remedio es que se traiga el azogue de Alemania ó de la China. Responden $\alpha$ esto que de Alemania ya se traen 4,000 quintales cada año sobre que S.M. tiene hecho asiento en Alemania y que no se puede traer más. Resp. que si se podrá traer más si se toma de veras este negocio y se paga a más precio del que ahora se dá, lo qual vendrá a ser en grande augmento de la hazienda real porque el azogue que puesto aquí no le cuesta a S.M. a 16 ps. lo podrá vender a más de 60 ó 80 a los azogueros y quando no huviese otra razón quite S.M. el estanco del azogue y dé licencia a los mercaderes de que lo traigan de Alemania que el interés lo hará que lo traigan y andará a rodo $\mathrm{Y}$ si en esto S.M. pierde algún interés, resp. lo primero $\mathrm{Y}$ principal que será muy bien perdido por asegurar su conciencia. $2^{\circ}$ que es pequeño. $3^{\circ}$ Que más pierde en que se destruyan sus indios tributarios $y$ asuelen sus provincias. $Y$ a lo de la China responden algunos con grandes 
quimeras de que es imposible porque sería menester una flota para traerlo y los enemigos la tomarían y otras cosas tan frívolas como esta; la verdad es que es muy factible y muy llano supuesta la grandísima abundancia que ay dello, porque S.M. tiene en Sanchón, puerto de la China, fatores reales y por medio dellos se podría comprar casi de balde y de allí a las Filipinas ay contratación orảinaria y asi cada año navegan aquellas 100 leguas muchos navíos y de allí a Acapulco bien se sabe que cada año vá una flota real de donde puede venir con gran comodidad y sin costa considerable y 6,000 quintales de azogue no es carga que requiere flota ni tampoco para su defensa requiere armada, pues no ay norvío pequeño en que no pueda venir más carga que esa y los enemigos no quieren azogue sino plata ni van a aquellos mares como piratas de navíos sino a sus contrataciones como nosotros y pues que se ha dado orden de que se traigan 4,000 quintales y sale muy bien no desmayemos sino pónganse medios eficaces para los 6,000 que faltan, aunque haya de costar alguna dificultad y trabajo el entablarlo, que será muy bien empleado para asegurar la conciencia real y quitar estas muertes y asolación de Guancavelica.

El $2^{\circ}$ medio es que heche S.M. a labrar estas minas todos los condenados a muerte, indios o españoles, ó los que más se puedan, que desde Quito a Tucumón serớn muchísimos cada año y en pocos se entablará la quantidad suficiente, lo qual sin controversia ninguna es justo porque se les conmuta la muerte natural en esta civil y ellos lo tomarán de muy buena gana y no es obra de crueldad de esta manera hechar a las minas sino de misericordia $y$ es lo que usaron los antiguos romanos $y$ otras naciones. A esto responden que no havrá suficiente número y que no se podrán detener porque se huirón. Son frívolas evasiones que pues los romanos y otras gentes se han dado maña para que no se huyan los forzados a minas, también nosotros la sabremos dar y podráse aunque sea hecharles prisiones. $Y$ también se huían los galeotes y los indios compelidos ahora a las minas pero tráenlos y pónense ministros para estos indios condenados a estas minas.

El $3^{\circ}$ medio es que se haga una ciudad o gran población de indios junto a Guancavelica o en ella misma y que allí se les den tales privilegios que ellos de buena gana y voluntariamente vengan allí a avecindarse como que no vayan a tales mitas ó que paguen menos tasa, que no les puedan compeler a servicios personales ningunos $\&$, este es medio que tiene S.M. mandado poner y no se ejecuta porque en todo lo que tiene alguna dificultad replican que no quieren sino su plata y azogue, como está entablado y sin más cuidado ni gasto y de lo demás de que se mueran y acaben los indios o de que se encargue la conciencia de S.M. o la suya no se les dá nada y no ay que decir que allí no poblarón, porque es mal temple, que no es mejor el de Potosí y los privilegios lo han de acabar todo. Dirás: despobláranse los pueblos. Resp. No importa como estén allí.

El $4^{\circ}$ medio me parece aún más fácil: que el Rey disse minas (como en Potosi, en Guancavelica a los particulares y les diese algunos privilegios o premios a los que más labrasen $\mathrm{y}$, si fuese menester, les perdonase el quinto de los azogues y fuese a la décima que con esto la codicia haría a los españoles que buscasen indios que de su voluntad se quisiesen mingar y no menos que los de ahora. Porque si en las minas de Oruro y de Caylloma se han labrado tan ricas minas y sacádose tanta plata sin indios de mita y sin dar S.M. azogue, aquí que no es menester azogue para la labor y donde los privilegios les atraerón, por qué no hemos de conceder que se podrán la. brar estas minas con indios mingas?. En los quales se quita la injuria y violencia, porque volenti non fit injuria. Dizen que no quita las muertes, pues 
han de ser menos los mingas que ahora son los de mita ni se mejorarćn por eso las minas ni causarán menos muertes que ahora. Dizen que esas mustes no las puede consentir el Rey porque será destruir los indios y despoblar los pueblos y asolar las provincias y que así tenetur ex justitia y ex officio a remediarlas. Resp. que es muy lindo que los que no quieren que sea injusticia que el mismo Rey heche forzados los indios al czogue, por otra parte digan que no puede el Rey permitir que voluntariamente se minguen. Digo, pues, que puede el Rey permitirles que se minguen, aunque se les hayan de seguir sus muertes, como puede consentir que se vendan ellos mismos por esclavos aunque no pueda el Rey venderlos por tales. Ni puede obligar al Reyno al servicio de los millones y puede recibirlos, si voluntariamente se le dá. Y esto no es injusticia, porque volenti non fit injuria ni la obligación que el Rey tiene de la conservación desta provincia, porque si ellos lo quieren aunque sea con su daño, por el mayor bien de toda la Iglesia de Dios y puede permitir que jueguen los galeotes y otras cosas semejantes, en lo quat nadie duda. Y aunque no dejarían de morir, serían menos porque ellos en viendo que les haze daño el azogue se quitarían del y no haría tanto daño porque se repartiría entre las demós provincias.

Finalmente destos medios todos digo que si qualquiera dellos no es bastante todos juntos lo serán y hazen evidencia moral de que el medio de hechar los indios forzados a las minas no es precisamente necesario para tener azogue con que labrar y sacar tanta plata como ahora se saca y pues lo que pudiera en alguna manera excusar sólo es la precisa necesidad que ay desta compulsión para que se saque este tesoro que se dize ser tan necesario para la Iglesia de Dios y para hazer guerra a los herejes y para la conservación de los reynos de España y destos, síguese que no ay excusa ninguna para quitar esta injuria y muertes de los indios de Guancavelica.

Art. 5-Que no es necesario a la Iglesia de Dios y a la conservación de España ni de las Indias sacar este azogue.

Quieren los que defienden estas minas de Guancavelica que sean absolute et simpliciter necesarias para la conservación de los Reynos del Perú, para que no se destruya la monarchia de España y para la fe católica y Iglesia de Dios, de manera que no avrá Indias ni España ni Iglesia si estos indios no son compelidos a estas minas aunque mueran en ellas y no les falta sino de. cir que se caeró el cielo si estos indios no son compelidos a sacar azogue destas minas. Y ya hemos probado por una vía evidentemente que esto no es necesario, probando que aunque fuera simpliciter necesario ese tesoro y para él el azogue ay modos posibles y factibles como se saque sin esta compulsión. Pero probemos ahora en este artículo que ni aun el sacar azogue quomodocumpo es simpliciter necesario y asi no puede justificar estas muertes y agravios.

$\mathrm{Y}$ en quanto a lo $1^{\circ}$ hazer dependiente la Iglesia de Dios de estas minas de Guancarvelica bien se ve que, por una parte, es cosa poco pía, immo, del todo impía, pues como non eget Deus nostro mendacio, tampoco de nuestros agravios y tan terribles opresiones para conservarse y defenderse de los herejes pues portae inferi non praevalebunt adversus eam. Quantos años estuvo la Iglesia de Dios más florida que ahora sin Guancavelica? Quanto mejor medio es para conservar la Iglesia de Dios quitar agravios, opresiones y tan enormes tributos que hecharlos sobre las vidas de los indios forzados y sobre 
las conciencias de los que las fuerzan?. Es posibłe que no tiene Dios en los infinitos tesoros de su omnipotencia y eterna sabiduría otro medio para conservar su Iglesia y defenderla de los herejes sino el azogue de Guancavelica y que no está fija en más sólido y inexpugnable fundamento la promesa y pro. fecía de Cristo: et portae inferi non praevalebunt adversus eam?. Bien se ve que estos son miedos soñados y que illic trepidaverunt timore ubi non erat timor. Y quando tantos tesoros como estos fueran necesarios ya hemos dicho que ni el Rey tiene obligación ni necesidad de estas guerras ni estos indios de cargar todars las obligaciones de la Iglesia de Dios sobre si sino que sa distribuyera por partes iguales o proporcionales pare toda la Iglesia de Dios o siquiera por los Reynos de España.

Casi la misma es la respuesta a lo de la precisa necesidad de los Reynos de España. Lo $1^{\circ}$ negando tal necesidad. Pues como se conservó España tantos siglos sin Guancavelica se pudiera conservar ahora. Antes muchos niegan ser verdadero y sólido bien de los reynos de España la mucha plata que saca, porque dizen que la mucka prosperidad y abundancia ha traído consigo el demasiado regalo, superfluidad en gastos y ociosidad, juegos $y$ pasatiempos y con ella se an afeminados los ánimos de los españoles, antes más fuertes y duros para cualquier honesto trabajo y que de aquí ha nacido Ia corrupción de nuestras costumbres que ha minorado la fortaleza españoia y su fama y reputación en las armas y que la plata ha empobrecido a España $\mathrm{y}$ enriquecido a las naciones extranjeras, porque no ha sido España sino una canal de su plata que corriendo perpetuamente por ella no para en ella sino haze estanque y se rebalsa en las demas naciones y que ha sido causa del inestimable empeño que tiene de tantos millones que la tienen destruída y imposibilitada de remedio. Pues si la grande abundancia de plata y inmensos tesoros de España han causado en ella la corrupción de costumbres y grande pobreza y empeño que vemos, cómo nos persuadiremos que no podrá España conservarse sin esta plata que tanto daño la ha hecho?. Quien se puede persuadir que no avró fé ni religión ni fuerza para resistir a los enemigos herejes o no herejes en España sin tanta plata? Quando del demasiado fausto $Y$ pompa con que se vive se quitara una muy gran parte, no es cierto que no sólo no hiziera daño sino hiziera mucho provecho?. Y siendo cierto que de las rentas reales las más son de España y otros reynos y que del $\mathrm{Pe}-$ rú no va a S.M. propio sino millón y medio y tiene 22 de renta, quien puede decir con fundamento que deste millón y medio depende toda España?. Y este millón y medio de sola Guancavelica? $y$, dado que fuera así que sea del todo necesario para la conservación de España, si España tiene esta necesidad, porqué ha de cargar sobre Guancavelica?. Y siendo cierto que quando un Rey es señor de muchos reynos los tributos se han de hechar a cada conforme a las necesidades dellos y no conforme a las de los otros reynos sujetos al mismo Rey.

Para la conservación deste reyno no solamente no es necescria la com. pulsión de los indios de Guancavelica sino es muy dañosa: porque si en 50 años se han consumido de 6 partes las 5 de los indios, en 10 años no quada ya ninguno y si entran nuevas provincirs, el mismo paso se han de ir asolando y quedarán todas las demás provincias comarcanas inhabitables $\mathrm{y}$, finalmente, se ha de venir a hazer (asoladas ya las provincias) lo que ahora se repugna que es no dar indios forzados a estas minas. Pero quando fuese así que la conservación deste reyno penda de alguna manera de la compulsión que se haya de hazer a estos indios, es fuera para las mitas de la labranza y crianza y para los servicios de los tambos, porque esto es simpliciter nece- 
sario para que los españoles se puedan conservar en esta tierra, porque si no no tendrían sustento, pero hecharlos a minas forzados en ninguna manera es forzoso para la conservación del reyno, pues sin eso avría plata más que sobrada para los gastos que tiene S.M. en el, que para los de los reynos extranjeros ya hemos dicho que no tienen obligación estos reynos y probado también que para ella esta plata no es necesaria. Y júntese la plata que se saca de Guancavelica, Oruro y Caylloma y las demás minas y la que en Potosí se saca con solos los mingas y los más mingas que avría de los que ahora ay si la mita cesara y se echará claramente de ver cómo la diferencia de la plata que ahora se saca a la que entonces avría es muy poca y que la plata que entonces se sacaría es más que sobrada para la conservación deste reyno.

\section{Art. 6--Respóndese a las objeciones.}

Resta responder a las objeciones que al principio se pusieron contra nuestra resolución y a la $1^{q}$ que estos indios son de naturaleza servil tienen respondido muchos autores que es falsísimo que sean siervos o esclorvos, que es gente que porque tiene poco de sabiduría, prudencia, experiencia y policía y poco también de valor son más para servir que para mandar, para ser gobernados que para gobernar se debe confesar, asi como todos lo confesamos. Al modo que decimos lo mismo de los labradores de España, máxime de los sayagueses. Mas que sean propiamente siervos o esclavos, incapaces de dominio y sujetos al Rey o a otros particulares como esclavos $\alpha$ su Señor... (nadie lo podrá afirmar). 


\section{Porecer de los PP. de la Compañía del Colegio Móximo de San Pablo sobre la Mita de Poiosí. 1670.}

Excmo. Sr. - Luego que recibí el papsl de V.E. sobre los agravios que padecen los indios en las mitas forzadas de minas y especialmente en la de Potosí, le comuniqué a los PP. más graves y doctos de este Colegio, noticiosos de las cosas del reyno y que han asistido en las provincias de donde se sacan indios para mitas de las minas: y todos de conformidad sienten $y$ son de parecer que aunque a los principios pudo tener S.M. justos motivos para imponerles esta obligación y gravámen, han usado y usan tan mal de él los Corregidores y Mineros, tratando a esta miserable gente con tan graves extorsiones y o.gravios que encarga S.M. Ia conciencia si se contìnúa mayormente en Potosí, donde las minas están más de 700 estados debajo de tierra y son tan pobres los metales que apenas se pueden costear; por cuya causa tienen por más conveniencia los mineros que la mita se reduz. ca a plata, de que ha resultado notable fatiga a los indios, pues que hazen el entero en plata (que de ninguna suerte pueden en persona, por estar las provincias casi desiertas) venden sus pobres alajas y ganados y temiendo el rigor se ausentan de sus provincias desamparando sus casas, mujeres e hi. jos y han sucedido casos de notable desconsuelo, tanto que muchos se han ilegcrdo a ahorcar y despeñar.

La tarea es ton continua que los obligan $\propto$ trabajar de suerte que no les dejan tiempo para que se puedan instruir en los misterios de nuestra santa fe cathólica de que están careciendo en dispendio de sus almas y grave cargo de conciencia y asi viven como gentiles muchos de ellos y otros pasóndose a tierras de infieles que están circunvecinos a sus partidos hazen más dificultosa la conversión de aquella gentilidad con la noticia que les dan de los agravios que padecen por vivir entre españoles.

La Compañía tomó a su cuidado la doctrina de Juli y por excusar estos inconvenientes y otros muchos que se expresan en la carta de V.E. los PP. que allí están embían la mayor parte de la mita en plata, haziendo que los indios tengan sementeras para que con lo procedido de sus frutos se rediman de la molestia que padezen en Potosí.

$\mathrm{Y}$ así toda esta comunidad agradece el santo celo y vigilancia con qùe V.E. atiende al alivio de estos miserables y que tanto se desea porque no acaben de consumirse los pocos naturales que han quedado en estas Provincias $y$ así nos parece que S.M. gravará su real conciencia si no se conforma con el parecer y dictamen de V.E. que es lo que se ofrece responder. Guarde Dios a V.E. muchos y felices años para bien y amparo de este rey. no. De este Colegio de S. Pablo. Junio, 26 de 1670.

Luis Jacinto de Contreras - Ignacio de las Roelas - Ignacio de Arbieto - Diego de Avendaño - Christóval de Arandia - Jacinto de León Francisco de Soria - Bartolomé Messía - Rodrigo de Valdes - Miguel de Lerma - Joseph de Torres - Joseph de Larrea - Andrés Gamero - Benito Bravo - Juan de Cantoral - Tomás de Manosalvas - Jacinto Barrasa Diego de Eguiluz - Francisco de la Maza - Antonio Lainez - Pedro López de Lara.

(Síguese la certificación del P. Gabriel de España, Secretario del P. Provincial, de ser auténticas las firmas del escrito de arriba, todos los cuales asistieron a la junta convocada por el P. Provincial y en el cual se examinó el papel del Conde).

Archivo de Indias. Charcas 268. 


\section{Carta del Conde de Lemos a S.M. sobre la Mita de Potosí.}

Señor.- D. Francisco de Toledo que fué el Primer Virrey del Perú que dió leyes y Ordenanzas a los indios le governó 14 años y desde 26 de Noviembre de 1569 hasta 17 de Mayo de 1581 que le sucedió D. Martín Henriquez revisitó, numeró y puso tasa a los indios que se hallaron en este Reyno, sin incluir en la numeración las Provincias del Tucumán, Paraguay y Buenos Ayres y Chile ni los 6 Corregimientos más cercanos al distrito y jurisdicción de la Rl. Audiencia de Quito.

En esta numeración y revisita se hallaron 1'077,697 indios. Los 277,697 dellos fueron áviles para pagar las tasas y tributos que les señaló y los 800 , 000 indios restantes quedaron reservados de pagar tasas y tributos, por biejos mujeres y muchachos.

Redujo este copioso número de indios a 614 repartimientos que, por otro nombre, se llaman encomiendas $y$ a diferentes pueblos que les mandó fundar, sacándolos de las rancherías en que vivían desde el tiempo del Inga y su gentilidad, señalándoles curas que les administrasen los SS. Sacramentos y educasen en los misterios de nuestra santa fee católica. Y para que se co brase dellos lo que devían pagar cada año por sus tasas y tributos y fuesen mantenidos en justicia instituyó, creó y señaló corregidores en otras tantas Provincias, agregando a cada una la parte que les cavía en prorrata de los 614 repartimientos.

Adjudicó para el cerro rico y minas de Potosí 13,800 indios, dejando obligadas 16 Provincias al entero de esta mita y con rebajas que ha ido ocasionando la disminución de los indios y su menoscabo han quedado en pocos más de 3,000. Las provincias están tan faltas y acavadas que de ninguna suerte pueden continuar el entero de la mita y lo que sucede es que la procuran ajustar los Corregidores de las 16 Probs. por mano de los Curacas, mandones, Caciques y Governadores y en orden a que esto tenga efecto usan de medios sangriéntos y rigurosos, colgando a los indios de los cabellos $y$ en muchas partes ponen horcas, meten en cárceles rigurosas $y$ azotan con crueldad.

Biéndose oprimidos los indios se huyen y ausentan de sus pueblos y muchos dellos se retiran a tierras de infieles $y$ otros se han dejado despeñar con sus hijos y mugeres pereciendo a manos de su misma cobardía y ha avido indios que han quebrado las piernas $y$ brazos a sus hijos por no verlos sujetos a la esclavitud desta mita.

De algunas Provs. los lleban en colleras, pendientes de la cola de un caballo, en distancia de 80 y 130 leguas, con que es de creer van arrastrados y llegan lastimados al trabajo y ocupación de la mita. Los Corregidores se ven obligados $a$ valerse de medios tan inhumanos $y$ formidables para ajustar el entero de su obligación, por excusar que el Corregidor de Potosí no les haga causa y ponga en una cárcel embiando jueces que los destruyan. 
$Y$ es el caso que los indios poseían y beneficiaban muchas tierras aun mas de aquellas que avían menester para su sustento y de lo procedido de los frutos que llevaban a vender a Potosí enteraban sus mitas, dando el dinero necescrio para que se alquilasen indios en lugar de los faltos o de los que se querían redimir desta ocupación como oy sucede en los indios de Juli, cuya enseñanza y doctrina está a cargo de los PP. de la Compañía de Jesús.

Y como en la repartición que se hizo en el govierno del Marques de Manzera les dejaron las tierras suficientes para sustentarse pero no las que avían menester para el entero de la mita se huyeron y ausentaron a provincias exentas de esta obligación.

Estos inconbenientes siendo tan graves y escrupulosos han crecido más desde que el Marqués de Manzera en virtud de cédula de V.M. hizo vender las tierras que poseían los indios, porque como quedaron desacomodados y sujetos a la opresión y trabajo de la mita se esparcieron en todo el Perú buscando el alivio y descanso que soliciton las fieras, retiróndose muchos de ellos a tierras de infieles con que se a hecho inasequible el entero de la mita. mita.

Oprimidos los Caciques, Governadores, Curacas y Mandones de la abligación del entero, porque los Corregidores de las 16 Provs. lo fían de su cuidado le procuran con todo anhelo $\mathrm{y}$ vigilancia $\mathrm{y}$ por librarse de las molestias y vejaciones que pueden padecer enteran en persona algunos indios, sin deducir los de la séptima que ay en todos los pueblos, como V.M. Io tiene mandado para que puedan descansar 6 años, cohaviten con sus mujeres y beneficien las tierras y por librarse del desamparan los indios sus tierras, casas y familias, con desconsuelo de sus hijos y mujeres.

De aquí nace otro incombeniente mayor, porque como están casi los más pueblos desiertos y desamparados recae la obligación de todos sobre los presentes y sin remuda ni tener descanso acuden a la mita.

En algunas Provs. nombran capitán general que sostituyendo por el Corregidor conduce y entera la mita en Potosí con cargo de que acavado el tiempo de ella vuelva los indios a sus pueblos.

Y si al Capitán General, pongo por ejemplo, no le entregan en las Provs. de su cargo más que 200 indios, le hacen enterar 500 , si son tantos los que deven enterar sus Provs. como si fuese suya la obligación, para cuyo efecto lo prende el Corregidor de Potosí, embarga y vende sus bienes. haziendo que por cada indio falto pague 7 ps. Y medio a la semana, cuyo entero por la especulación que hizo el Conde de Alba de que dejó relación en este govierno importa en cada año más de 700,000 ps. fuera de los indios que se enteran en persona, según consta de un testimonio que le embió el Obispo D. Fr. Francisco de la Cruz, a quien cometió la visita y apuntamiento general de la mita y para que esto se entienda mejor me explicaré más.

Los Corregidores apremiando a los Curacas recojen la mita y por no aver indios en las provincias para el entero efectivo de su obligación según la última revisita la recojen parte en persona, parte en plata y parte de prometido, de todos hazen lista como si fuesen en persona, con nombres supuestos que llaman indios por párrafos; nómbranse capitanes particulares que recojen los de su cargo y capitán general que sostituye por el Corregidor sobre todos. Llegan al desaguadero de Potosí, donde se hace la entrega y porque de ella ha de dar testimonio un escribano combidan indios para que allí parezcan y con los nombres que lleban en las listas pasan muestra, andando al moyo, esto es a la redonda. 
Llénase la lista de que da testimonio el escrivano el qual se remite al Corregidor de Potosí, ante quien y los azogueros interesados se presenta el Capitán General, refiriendo en verdad los indios que ha traydo de las provincias en persona. Pero le combencen con el testimonio y entrega $y$, amenazado, ofrece enterarlos en plata y con efecto por redimir la bejación entera por cada indio falto en cada semana 7 ps. y medio para que se alquile otro en su lugar. La semana tiene 5 días de trabajo, porque el Lunes no se cuenta, respecto de que se consume en repartir, los indios y hacerlos que entren en la mina. Con esta ocupación están todo el año divertidos en la mita los indios, caciơues y governadores, sin que tengon tiempo para instruir en los misterios de nuestra Sta. Fee Cathólica ni acordarse de que son christianos y así viven con el poco temor de Dios, que es notorio y descuido de su gentilidod. Al indio de mita como llevo referido no se le paga el lunes, estando ocupa. do en el entzro y prompto al trabajo, demás que el conducirlo y entrar en la mina es precio estimable, con que al año le dejan de pagar 52 días que entre todos importa cantidad más considerable en tantos años como ha que esto introducida cquella mita.

El jornal del indio de mita es de $4 \mathrm{rs}$. pagando 12 al que se alquila por servicio voluntario; en que hago dos reparos, el primero en la desigualdad de ambos jornales; el segundo que los $4 \mathrm{rs}$. que el minero havía de pagar al indio de mita cada día, se devían rebajar de los 12 que entrega el minero para que se a'quile otro en su lugar, pues de lo contrario viene a resultar que el minero se sirve del indio sin pogar el jornal que devía pagar al indio de mita, injusticia que procuró remediar el Conde de Alba, despachando provisión para ello, pero no ha tenido efecto porque como los ejecutores son inieresados en estas y otras conveniencias no se sujetan a las leyes, cédulas Y provisiones reales y sólo ejecutan lo que puede ceder en su favor y aumento de sus haciendas.

Por estar así todas las provincias destinadas a esta mita desiertas y desamparadas no pueden los caciques y capitanes generales acudir con la mita por entero y conforme la ordenanza despacha jueces el Corregidor de Potosí con días y salarios que causan las injusticias y agravios siguientes: cobron en dinero a razón de 7 ps. y medio por cada indio falto, sin averiguar. si estan vivos o muertos; no se considera si están impedidos o enfermos; no se baja en la cobranza lo que havían de aver si trabajasen; tampoco se recive en quenta lo que se les devía pagar por la ida y buelta; cobran los rezagos y faltas que hicieron los fugitivos de los que estón sin culpa y presentas en sus pueblos pagando unos el delito que cometieron otros; ejecutan esta pena y condenación siendo tan grave sin que aya ley ni ordenanza que lo disponga; cobran indistintamente los rezagos, los mineros que usan bien y mal de los indios, con que se cobran los de plata y faltriquera en que ay diferencia. (Llaman indios de plata cuando se alquilan otros que trabajan con el dinsro que va de las provincias por quenta de los indios faltos y de faltriquera quando los mineros se quedan con el dinero, sin restituir otros en lugar de los que faltan) y ay hombre en Potosí que, por no tener labores se apro vecha de 30,000 ps. al ar̃o y muchos de 6 y 8,000 sin dar un solo real de beneficio a la Real Hacienda; no se sustancia la causa, dando defensa a los indios y cobran a bulto por los que faltan que es lo mismo que por los muertos $y$ ausentes que no se ve donde están. Desta calidad de rezagos nada pertenece a V.M.

No consta antecedentemente de los daños que padecieron los mineros: la que puede ser culpa del Corregidor, estanciero o cacique la pagan los indios particulares; cobran los rezagos y falta de la mita de los presentes, sien- 
do notorio que los indios son pobres de solemnidad; váse contra provisiones y ordenanzas expresas del Govierno que mandan que los indios no secon condenacios en dinero por ninguna falta. No prefieren siquiera el sustento de los indios y de sus hijos y mujeres en esta cobranza; ban jueces con días y salarios sin saber contra qué reos; queda la obligación en el dinero, no haviéndola en la persona; condenan al indio que falta y no se acuerdan del español que lo detiene en su casa o hacienda sin dejarlo ir a su pueblo; no se admite excusa ni excepción contra los rezagos siendo notoria la dificultad que ay en la reducción de los indios a sus pueblos y falta en las provincias $\forall$ últimamente, se save que están los más de los indios en las provincias que ni mitan y se cobran de las que mitan, deviendo tener más alivio por más afligidas y apuradas .

Con esta opresión y tiranía se a continuado la mita de Potosí que han lamentado muchas personas celosas del servicio de Dios y de V.M. teniendo por injusta esta ocupación y contraria al derecho natural. Con ella les falta tiempo para educarse en los misterios de nuestra Sta. fee cathólica y como he referido no cohabitan con sus mujeres ni cultivan sus tierras con qua se hace imposible la conservación y aumento deste reyno.

Huyen de sus reducciones y muchos se van a tierras de infieles, dejando en notorio desamparo sus hijos y mujeres por cuya causa están los pueblos y provincias destinadas a esta mita sin gente $y$ ay lugares en las Indias donde las mujeres hacen oficio de alcaldes por no haver hombres que lo puedan ser. A que se añade que los indios que buelven a sus tierras se hallan con el gravamen de pagar el tributo señalado por la tasa y con nueva opresión del Cura y Corregidor que los apremian cada uno por su parte a hilozas $\mathrm{y}$ tejidos $\mathrm{y}$ a que involuntariamente compren mulas, vino y aguardiente y a que cultiven las tierras por su cuenta y anden en sus chácaras, tratos y granjerías, haviendo consumido en ida y vuelia de la mita de Potosí en muchas provincias mós de 300 leguas, y es su mayor daño y perjuicio que este gravamen molestia y tiranía renace y se continúa en unas provincias continuamente $y$ en otras cadx 2 ó 3 años, sin que puedan tener descanso para la conservación de la vida humana. Y así tengo por cierto que las piedras de Potosí y sus minerales están bañados en sangre de indios $y$. que si se exprime el dinero que de ellos se saca ha de brotar más sangre que plata.

Y en prueba de esto diré en breve lo que me ha sucedido con el Corregidor y azogueros de Potosí. Tube noticia de tres cosas dignas de prompto remedio: hacían trabajar a los indios de día y de noche metidos 600 estados debajo de tierra con una barreta en las monos que la que menos pesa tiene más de 30 libras de hierro, entrando el Lunes en la mina en que están sin horas y tiempo de cada día que huviesen de trabajar sin que el trabajo sea ver la luz del sol hasta el Domingo por la mañana que salen, de modo que ignoran quándo es de día y quándo es de noche en toda la semana, padeciendo grande incomodidad por las humedades del agua de que están llenas las minas y mucho frío que todo es de notable perjuicio a su salud.

La segunda obligaban al Capitán General de la mita a que enterase los indios que no le entregaban los Corregidores y a los que enfermaban $y$ morían en el camino o se ausentaban, después de hecha la entrega, sin cul. pa ni intervención del capitán general.

La tercera, despachaban jueces contra los corregidores por la falta de indios de años atrasados.

Viendo los grandes inconvenientes que deste abuso se seguían a la causa pública bien y conservación de los indios, determiné con parecer $y$ 
comunicación del Visitador D. Alvaro de lbarra que los indios conforme la ordenanza de D. Luis de Velasco, mi antecesor que con grande inteligencia especuló estas materias trabajasen de día y descansaran de noche. Esto mismo tiene mandado V.M. en diferentes cédulas en el primer tomo de las impresas en la pág. 321 , cap. 51 advierte V.M. que han de ser moderados estos trabajos y que sepan los que excedieren en ello que han de ser gravemente castigados.

En céduia del año de 1601 dispone V.M. que la ocupación de las mitas de minas sea con la limitación de tiempo, moderación de trabajo y justificación de jornales que declarare y ordenare el Virrey del Perú y en el cap. 26 se añade que se considere las horas del día que han de trabajar los indios, así en las minas como en las demás labores y si aquellas fuesen contra su salud y de mucha incomodidad y bejación suya, señale el Virrey las horas y tiempo de cada día que huviesen de trabajar sin que el trabajo sea excesivo ni mayor del que permite su complexión y fuerzas y de manera que no recivan daño en su salud.

Esto mismo se repite en la cédula del año de 1609, en el cap. 11, 33 y 34 y el Dr. Solórzano en su Política a f. 98 dice que conformándose con lo que dispone el derecho nadie puede ser oprimido a trabajos de noche sino es en un caso de inminente aprieto y necesidad y añade que siendo Governador de Guancavelica no se pudo ajustar a la costumbre que halló entablada de que unos indios trabajasen de día y otros de noche.

También ordené que el capitán general no tuviese obligación de en. tregar más indios de los que recivía en las provincias, según y de la suerte que se los entregasen los corregidores y que haviendo falta en el entero de la mita el Corregidor de Potosí despachase jueces contra los Corregidores a cuyo cargo estó el entero de la mita, sin que por ello fuesen molestados los caciques y capitanes generales y que esto fuese en cada año sin reserbarlo para otros, porque despachándose jueces para el entero de 6 o 7 años atrasados se ocasionaba el inconveniente de enterar unos corregidores lo que otros dejaron de hazer y que de una vez y como de golpe destrutasen las provincias $\mathrm{y}$ totalmente quedasen desamparadas las reducciones de los indios, dejóndolos con el gravamen de que unos mismos vuelvan a continuar el año siguiente en esta formidable ocupación y sin el descanso que han menester para conservar la vida humana. De la ejecución de estas tres órdenes han resultado muchas quejas del Corregidor y mineros de Potosí, amenazándome que han de tener grande baja los quintos reales si no mando que los indios trabajen de día y de noche, paliando el abuso con diferentes pretextos ajenos de toda razón, tanto que haviendo mandado que se juntasen todos y confiriesen el medio más suave y proporcionado para que se hiciese la numeración de las 16 provincias destinadas a la mita, me respondieron que la numeración se podía hazer por los curas y corregidores, con cuyo parecer no me he conformado porque estos son los más interesados en la oculiación de los indios y fiándolo de su cuidado podría ser tuviese grande baja la mita por cuya causa fué deste mismo dictamen el Conde de Alba y el motivo principal que tienen los mineros para querer que por este medio se haga la numeración no se encamina al servicio de V.M. sino a la conveniencia que deste luego reconocen en excusar la paga y satisfacción de los jueces, escribanos y alguaciles que pueden ir a numerar las provincias y así en quanto a este punto insisto en lo que tenga escrito en carta aparte, caso que V.M. determine se continúe el trabajo y ocupación de esta mita (que Dios no permita). 
También me escrivieron que renunciaban la numeración si no se mandava que los indios trabajasen de día y de noche y juntamente no se nume. raban otras 16 provincias que por todas hazen 32 , aunque no estaban destinadas a la mita. A que respondí que sin orden particular de V.M. no podía ni devía mandar que se agnegasen nuevas provincias a la mita de Potosí ni que los indios trabajasen de día y de noche, advirtiéndoles lo que tuve por conveniente, en orden al aumento de los reales quintos y tengo escrito al Corregidor que le suspenderé del oficio y castigaré severamente si por su. culpa tienien baja y disminución los reales quintos.

$Y$ sin tener noticia de los incombenientes referidos de que brevemente y como por índice he informado y hecho mención en esta D. Fr. Gerónimo de Loaiza, primer arzobispo desta ciudad, se retractó estando para morir del parecer que le dió a D. Francisco de Toledo en orden a que los indios po. dían ser compelidos a las mitas de minas, pidiendo en cláusula de su tes-. tamento se representase así a V.M. (I).

Lo mismo sucedió a Fr. Miguel de Agia, religioso de S. Francisco que mudó el parecer que dió a $\mathrm{D}$. Luis de Velasco, después que reconoció por vista de ojos el quebrantamiento de la libertad natural, juzgando por injusta la ocupación de las mitas forzadas de minas. Y si esto reconocieron entonces, qué dirían en el estadio presente, donde como a porfía se han ido cada día aumentando los agravios que padecen los indios y la opresión y tiranía con que los tratan.

La Ley de partida manda que en los exércitos no cansen las bestias con las cargas, porque mueren muchas ó se dañan, que es cosa que se toma en gran menoscabo de la hueste, quanto mós se deve atender que los indios que son racionales y están declarados por libres no sean molestados con cargas tan pesadas.

Bien lo previno el Sr. Emperador Carlos V, en cédula de 1529 mandardo con pena de conficcación de bienes y perdimiento de los indios que ninguno los ocupe en las minas y en otra del dho. año de 1529 que se refiere en el $44^{\circ}$ tomo de las impresas, en la pág. 225, ordena que aunque los indios voluntariamente se quieran ocupar en este ministerio no los apremien a trc:bajar contra su voluntad.

Y despues, conocida la fragilidad, desta gente, su miseria y cortas fuerzas, en cédula de 1551, dirigida al Lic. Gasca, que governó este reyno, estrecha más esta materia con las palabras siguientes: "La provisión que decis que hizo el Obispo de Palencia al tiempo que en esa tierra estubo para que se sacasen de las minas los indios que contra su voluntad o con ella estuviesen en ellas e lo que después vosotros proveisteis me ha parecido bien para remediar parte del daño que esos naturales reciven, pero porque del todo cese, está por S.M. acordada provisión para que no se hechen en ninguna manera indios a minas, la qual con esta os mando embiar duplicada, ternéis cuidado de que se guarde y cumpla en todo $y$ por todo como en ella se contiene". Y la razón se deduce de otra cédula despachada el año de 1549 en aquellas palabras: porque no solo es en disminución de sus vidas sino también grande estorvo a su conversión a la santa fee cathólica y esto mismo reconoció el Sr. Emperador Carlos V, en cédula del a. de 1528 y vi, porque demás de ser esto en tanto de servicio de Dios N.S. y tan cargoso a nuestra real conciencia y contra la religión christiana porque todo es estorbo para la conversión de los indios a nra. santa fée cathólica que es nro. principal deseo e intención y lo que todos somos obligados a procurar, viene también desto mucho inconveniente para la población y perpetuidad de la tierra 
porque a causa de los excesivos trabajos que se les han hecho y hacen han muerto y mueren muchos.

Por redimir los cautivos se pueden vender los bienes de las Iglesias, cálices, patenas y haviendo prometido los SS. Reyes Católicos, progenitores de V.M. a la Santidard de Alejandro VI, al tiempo de la conquista de estos reynos, que quando conviniese derramarón su sangre real por la defensa y combersión de los indios, ha llegado el caso de que V.M. con su santo celo los ampare y defienda, sacándolos de la cruenta esclavitud que padecen en la opresión de la mita de Potosí no sea que el cielo oiga su continuo clamor que cada día crece y se haga más lamentable con la continuación de sus agravios y destruya totalmente este reyno, acrecentando los trabajos de la Monarquía pues no puede tener buen logro la plata adquirida por tan malos medios.

Es cierto que los indios se van consumiendo y acavando a toda prisa con las opresiones y malos tratamientos que reciben y las ausencias que de sus casas y haciendas hazen, sin quedarles tiempo desocupado para ser instruídos en las cosas de nra. santa fée cathólica ni para atender a sus granjerías ni al sustento de sus mujeres ni hijos de donde pende su conservación y aumento, como V.M. refiere en cédula de 1601 . Y tengo muy presentes los renglones qui de su letra y real mano puso el Sr. D. Felipe IV, el Grande, que está en el cielo, al pié de la cédula que mandó despachar el año pdo. de 1628 y ví: quiero que me déis satisfacción a mi y al mundo del modo de tratar esos mis vasallos y de no hazerlo, con que en respuesta de esta carta vea yo ejecutado ejemplares castigos en los que huvieren excedido en esta parte, me daré por bien servido y aseguraos que aunque no lo remediéis, lo tengo de remediar y mandaros hazer gran cargo de las más leves omisiones en esto por ser contra Dios y contra mi y en total destrucción de esos reynos, cuyos naturales estimo y quiero sean tratados como lo merecen vasallos que tanto sirven a la monarquía y tanto la han engrandecido e ilustrado.

Y porque el Arzobispo de Lima tubo descuido en no haver procurado por su parte el remedio de estos excesos o siquiera avisado dellos, el Sr. D. Felipe II en cédula de 27 de Mayo de 1582 le dice así: Y porque haviéndose proveido tan cumplidamente lo que ha parecido convenir al bien espiritual, temporal y conversión de los indios, teniendo tonto cuidado de procurar que fuesen doctrinados en las cosas de nra. santa fee, mantenidos en justicia y amparados en su libertad, como subditos y vasallos nros. entendíamos que nuestros ministros cumplían lo que les havíamos ordenado y de no haverlo hecho ni cumplido y llegado a estado de tanta miseria y trabajos nos ha dolido, como es razón y fuera justo que Vos y vuestros antecesores, como buenos y cuidadosos pastorss, hubiérades mirado por vuestras ovejas, solicitando el cumplimiento de lo que en su favor estó proveído o dóndonos aviso de los excesos que huvisse para que los mandásemos remediar y se cumpliese nra. voluntad que es de que estos pobres gocen de descanzo y quietud y conozcan a N. Señor para que mediante su divina gracia y la predicación del Sto. Evangelio puedan salvarse.

Estás cédulas y especiclmente la instrucción secreta que V.M. se sirvió de mandarme entregar, quando vine a governar este reyno, en que me dice descarga su conciencia real en fiar de mi cuidado la conservación y alivio de los indios, me necesitan a representar a V.M. con cierta y verdadera ciencia que tengo que los indios aplicados a las mitas de las minas, especialmente a la de Potosí, estan gravísimamente vejados, molestados y aflijidos. Así lo digo para descargo de mi conciencia. 
Y es sin duda que esta mita ha sido causa de muchos años a esta parte de grandes pecados y ofensas que se han hecho contra el servicio de Dios N.S. y de V.M. por el perjuicio y agravio notorio de los indios. Y que los mineros están incursos en la Bula de la Cena como infractores de la libertad natural y si V.M. no toma resolución de quitar esta mila forzada donde tantos inconbenientes ha mostrado la experiencia se vendrán a accibar y aniquilar totalmente las provincias con grave cargo de la conciencia real. Así lo juzgo; así lo siento y afirmo y de este mismo dictamen y parecer han sido muchos hombres doctos y religiosos.

Y haziendo el ánimo de que V.M. no quiere los tesoros de Potosí por excusar tantos pecados y agravios como se an cometido y cometen cada día, tengo viva fe de que Dios premiará el santo celo de V.M. dándole por otra parte mayores riquezas. Haviendo oído al Procurador del Mineraje de Potosí y conferido largamente este punto con el Visitador D. Alvaro de Ibarra, concurriendo en la conferencia muchas veces el Fiscal y Protector General, con el celo y cuidado que devo y pide mi obligación, juzgo que V.M. según el estado presente de la monarquía, tomando medio en esta materia, deve mandar por lo menos se quite desde luego la mita forzada de Potosí y que acudan a las lavores del cerro los indios que voluntariamente quisieren trabajar. De aquí pueden nacer muchas conveniencias a la conservación del reyno y a la real hazienda.

Los que tuvieren minas que poder trabajar en Potosí lo harán con indios vointarios. Descansarán las Provincias y los indios ausentes y fugitivos volvercin a sus reducciones. Más de 24,000 indios estón avecindados en las rancherias de Potosí y los que tuvieren codicia y voluntad de quedarse allí se podrán alquilar voluntariamente obligóndoles solo la seguridad de ia paga y busn tratamiento de los azogueros como se experimenta en algunos asientos de minas que no teniendo mita forzada están poblados los ingenios de indios voluntarios. La dificultad consiste que siendo pobres los metales de Potosí no podrón sanear la costa pues ha de ser el jornal no cómo a indios de cédula sino el que corre en Potosí con los voluntarios y en otras partes donde no estón repartidos indios. A que se responde que los azogueros de Polosí con la codicia de que en la mayor parte de la mita se entera en plata traen labores por cumplimiento, sacando los metales que bastan a manifestar con apariencia que trabajan porque no les quiten los indios y desengañados deste socorro, de necesidad trabajarán, por no despoblar los ingenios, procurando con los indios que adquiriere su industria $y$ buen tratamiento mejorar su fortuna. Si se tomara esta resolución con brevedad se excusarón muchos pecados, cuidados $\mathrm{y}$ alborotos quedarán las cosas en su lugar $y$ sin el peligro que trae consigo el medio que se huviere de elegir para reformar el abuso de Potosí, que es imposible hablando moralmente, porque han de matar al juez que lo quisiere remediar y se ha de consumir largo tiempo sin poder llegar al fin que se desea, como sucedió en todo el govierno del Conde de Alba y en más de 5 años que governó el Conde de Santisteban, tratando continuamente desta materia y sin esperanza de poderla componer, tanto que viendo las imposibilidades de ajustar la mita en persona y Ias grandes dificultades que se ofrecían, escribió papel al Visitador, D. Alvaro de Ibarra pidiéndole parecer sobre si podía y devía mandar que se enterase en plata, por excusar la bejación y molestia que padecían los indios. A que respondió era injusticia notoria y contratsu libertad reducir a plata el servicio de los indios que se introdujo por excusar la ociosidad, como consta de un tanto del papel y respuesta que va con esta: Por este medio juzgo se vendrón a reducir los indios voluntariamente a sus pueblos, contentándose 
con las tierras que les dejaron, por no tener necesidad de frutos que vender para el entero de la mita. Crecerón los tributos en beneficio de la Real Hacienda y a pocos años será manifiesto el aumento de las provincias.

Los quintos de Potosí importan menos de 400,000 ps. cada año, con poca diferencia, porque lo demás proviene de otros derechos reales, paga $y$ satisfacción del azogue que se vende de quenta de S.M. con que lo que se arriesga no es tanto como lo que viene de aquellas cajas.

Todas las minas han tenido término y último fin; ya no dá metales de buena ley el cerro de Potosí y la mayor parte de los que se funden y benefician en los ingenios de aquella villa se traen de los contornos y minerales más cercanos, dando a entender que son del cerro; han conservado los mineros el engaño de la mita. Esto lo confiesan el Corregidor y mineros de Potosí en diferentes cartas que me han escrito por donde juzgo se ven obligados a fatigar y apremiar más a los indios, queriendo con la mayor saca de metales suplir la menos ley que tienen, agraviando a los indios en la ocupación y trabajo y solicitando que de otras provincias ro destinadas no destinadas a la mita lleven indios para acrecer la saca de metales y suplir la falta que se reconoce en las provincias destinadas con los muertos y ausentes, en que ay tanta disminución que el Obispo Cruz, en carta particular que escrivió al Conde de Alba refiere que de algunos pueblos llevaban las mujeres para poder llenar el número de la mita, lo qual prohibió el Conde con graves penas y oy sólo en la provincia de Pacaxes van en párrafos más de 900 indios, según un testimonio que reciví el año pasado del Corregidor de la Provincia que tengo en mi secretaría, los quales se enteran en plata.

Otro remitió el Obispo Cruz al Conde de Alba en que se refiere que de la Provincia de Porco havía más de 4 años que se enviabon 60,000 ps. cada año para el entero de la mita, según la relación que dejó en este gobierno firmada de su nombre. Y el Presidente D. Francisco Nestares Marín, ministro celoso del real servicio refiere que este abuso está introducido en Potosí y que muchos mineros se quedan con la plata porque tienen más conveniencia en retenerla que en trabajar en las minas y que esto es causa de que los quintos sean tan cortos y las provincias estén destruídas y aniquilacias.

El Obispo Cruz en carta que escrivió al Conde de Alva, su tha. 2 de Agosto de 1659, añade que la disminución de los Rs. quintos en los años antecedentes se originó de estor 38 ingenios de la rivera de Potosí parados y algunos dellos desiertos y que en muchos de los corrientes solo molían pallacos, que así llaman al metal pobre, de que se reconoce quantos motivos concursen para tomar esta resolución.

$Y$ porque puede ser que sin embargo, de la urgencia de estas razones Y de ser de tanto escrúpulo y gravamen a la conciencia real, pues oy se hallan los indios, siendo libres y sin haver cometido delito, condenados al metal que, fuera de la pena de muerte, es la mayor que hallaron los romanos, parazca árdua esta propuesta queriendo preferir al servicio de Dios y de V.M. la conveniencia de los quintos, que de ninguna suerte se pueden sacar sin incurrir en los inconvenientes que he referido, que no me prometo de la real clemencia de V.M.

Sería no de tanto perjuicio conservar con indios voluntarios la laver de Foiosí, donde están avencindados muchos que lo pueden hacer y aplicar los indios de esta mita a S. Antonio de Esquilache, Carangas, Cailloma, Puno y otrós minerales cercanos a las provincias, dando las órdenes convenientes para que sean bien tratados y no molestados, aumentándoles el jornal y qui- 
tando de raiz los indios de plata porque este venero introducido en Potosí está allí tan arraigado que sino es por este medio siempre $s \geqslant$ ha de continuar.

Los mineros y corregidores de Potosí no han tenido otra delensa para las tiranías que han obrado que intimidar a los Virreyes, Presidentes y Oidores, asegurando se acaban los quintos Rs. y pierde la Monarquía, como lo han hecho conmigo y asi no se an atrevido a poner la mano con el rigor que pide este exceso. Antonio López de Quiroga, que es el minero más rico de Potosí, estubo conmigo en Puno y me asəguró que si los metales desechados de aquel asiento tuviese Potosí, diera una grande riqueza. Pues qué razón ay para que por conveniencia de 4 o 6 interescados que tiene Potosí se aplique toda la fuerza de los indios al cerro, a título de que fué mina rica, pudiéndose en otras partes sacar más utilidad y provecho, con menos vejación Y molestia de lus indios.

$Y$ por si estas razones no movieren el ánimo de $V . M$. a tomar la resolución que propongo, se ha de servir de mandar confirmar los 3 puntos que he determinado en favor de y alivio de los indios, declarando si se an de apuntar las 16 provincias que de nuevo piden los mineros de Potosí, con presupuesto que si esto se ordenare se acavorán de todo punto las provincias.

Y para que V.M. reconozca el motivo de esta pretensión y los inconvenientes que se ofrecen por una y otra parte los referiré brevemente. Es así que muchos indios de los que están destinados a la mita de Potosí se han avecindado en otros 16 provs. que no tienen esta aplicación, así porque no les dejaron tierras suficientes, para demás del sustento, poderse ayudar al entero de la mita, quando se vendieron de orden del Marqués de Manzera, en virtud de cédula de V.M. que era el único medio con que se conservaban en sus reducciones, según tengo referido, como porque se quisieron exonerar del riguroso trabajo de la mita, ausentándose a partes donde no pudiesen ser aprendidos.

Alergan los mineros que estos no deven ser de mejor condición que los que quedaron en sus pueblos y reducciones, sujetos al trabajo y ocupación de la mita. Por la parte contraria hazen las razones siguientes que tuvo por tan eficaces el Conde Alba que no se atrevió a tomar resolución en este punto. Los indios adquieren domicilio por 10 años de que dicen no pueden ser despojados sin que se les haga injusticia; haviéndoles quitado y vendido las tierros que poseían, señalóndoles otras en pedregales y de poca utilidad, pero suficientes para sus sustento, se retiraron de sus provs. huyendo la opresión y vejaciones de la mita, por no tener recompensa en los trutos que producen las que les dejaron con que poderse ayudar al entero de la mita en plata, como lo hacían por lo pasado, redimiéndose de tan rigurosa ocupación. Es tan eficaz el derecho del domicilio que el Príncipe de Esquilache, siendo Virrey deste reyno, despachó provisión en favor de los indios destinados a la mita de Potosí, en 15 de Marzo de 1617. Y también el Conde de Salvatierra, con parecer del Rl. Acuerdo en 26 de Noviembre de 1654.

Los indios que se hallan cercanos a los Chunchos y otros infieles, oprimidos con esta novedad, harán tránsito a ampararse dellos como lo han hecho otros. Hallándese connaturalizados en otras provs. de temple caliente, sería de grande riesgo a su salud reducirlos ahora a Potosí, inconveniente que reconoció D. Francisco de Toledo en la reducción general que hizo en este Reyno y que V.M. tiene prevenido por diferentes cédulas. Es impracticable esta reducción por falta de personas que la hagan y ejecuten como se deve y fuera diligencia con manifiesto agravio de los indios $y$ de ningunx utilidad a V.M. y a los interesados. Han de desamparar los pueb'os donde los pusiesen contra su voluntad. 
Los mós indios avecindados fuera de su origen son ya hijos y nietos de los originarios de las 16 provs. que conservan el nombre de forasteros, por sus abuelos y padres y quererlos apuntor para la mita, sacándolos involuntariamente de las provs. donde nacieron para que acudan a mita forzada en Potosí tiene grande inconveniente, además que es de recelar que este veneno se penetre en los demás indios que no son originarios de la mita y por librarse deila se perturben las provincias haciendo lo mismo que hicieron los que se acogieron a ellas. Daño que con el tiempo no se ha de poder remediar y si acaso quedaren los indios originarios de la mita de Potosí en las provincias donde oy residen que lo tengo por imposible, queriéndolos apuntar para mita forzada, sin duda ninguna serón indios de plata y de faltziquera, como hasta aquí se ha continuado que ha sido la causa de su destrucción $y$ ruina.

Esto es lo que se me ofrece representar a V.M. en orden a que del todo se quiten estas mitas forzadas, no haviendo razón divina ni humana para que reconocidos tantos $y$ tan graves inconvenientes como la experiencia ha mostrado se conserven y continuen, especialmente en Potosí, donde con la falta de buenos metales gravon mós a los indios.

Espero la resolución de V.M. que ejecutaré con toda obediencia y rendimiento pues haviendo asegurado mi conciencia con este informe he cumplido mi obligación y quedo con mucha confianza de la Rl. clemencia y santo celo de V.M. que en materia que tanto importa mandará lo que mús convenga. Guarde Dios la C.R.P. de V.M. como la christiandad ha menester. Lima, 4 de Julio de 1670. - El Conde de Lemos.

A. DE I. CHARCAS 268. 


\section{Carta de la Provincia de los 12 Apóstoles del Perú al Conce de Lemos. jE7c.}

Excmo. Señor.-Aviendo reconocido el informe y relación que V.E. hace a S.M. sobre las mitas forzadas de los indios para las minas de este Reyno y los grandes inconvenientes que en la execución se han experimentado, tratónảolos con más rigor que si fuesen esclavos, especialmente en la mita forzada de Potosí hice juntar los PP. doctos y graves de este convento de N.P. San Francisco de Jesús de Lima y los que pueden tener noticia cierta de los inconvenientes que se expresan en el informe y todos de conformidad juzgamos que V.E. como tan atento governador y celoso en el servicio de Dios deve hazer esta propuesta a S.M. y que la real conciencia estará gravemente agravada si de todo punto no manda quitar las mitas forzadas especial mente las de Potosí, donde en la execución se han reconocido tantos y tan graves inconvenientes que no ay nación por bárbara que sea que esté tan vejada y oprimida como los indios a quienes no a quedado ni la sombra de libertad. Asi lo sentimos, afirmamos y juzgamos y pedimos a Nro. Señor guarde a V.E. muchos años con toda felicidad. Junio 26 de 1670.-Excmo. Señor. Besan la mano de V.E. sus menores capellanes. Fr. Francisco Delgado, Guardión de Lima. - Fr. Gonzalo de Herrera, Padre de Provincia.- Fr. Diego de Herrera, Padre de Provincia.- Fr. Pedro de Ayaz, Padre de Provincia.- Fr. Juan de Torres, Padre de Provincia.- Fr. Antonio de Ozerin, Diffinidor y Lector Jubilado.- Fr. Joseph del Castillo, Diffinidor actual. - Fr. Blas Durón, Diffinidor.- Fr. Francisco de Aramburú, Diffinidor.- Fr. Joseph de Guadalupe, Lector Jubilado. - Fr. Cristóbal de Contreras, Lector Jubilado y Custodio.- Fr. Cristóbal Jaramillo, Lector Jubilado.- Fr. Mateo Revata, Lector Jubilado. - Fr. Juan Suórez, Lector Jubilado y Regente de los Estudios.

(Síquese la certificación de Fr. Domingo de Valdes, Vicario del Convento de Jesús de Iima y Notario Apostólico, de cómo los PP. que arriba firman han oblenido y obtienen los oficios que allí se dice y son de los más graves de la Provincia. 3 de Julio de 1670).

\section{Caria de la Provincia Agustiniana del perú al Conde de Lemos. 1970}

Excmo. Sr. - Dando gracias a Nro. Sr. de ver se trata con eficacia $y$ veras de poner remedio en la materia que tantos años lo es de la compasión de quantos la miran sin interesarse la miran y oyen y el empleo de las voces de muchos predicadores evangélicos, leí el informe que V.E. se sirvió de remitirme en orden a que se excusen las mitas forzosas de los indios a minerales y en especial al de Potosí por los abusos que se han introducido y confiriéndolo con los padres de más experiencia y letras que tiene este convento fué una la voz de todos, acompañada en algunos de ternura. Menos dice este papel con decir tanto que lo que hemos visto. Mayores y más continuas son las extorsiones que las que en el se pregonan. Quantos de los que estamos aquí hemos visto y qual (se preguntaron) no ha oído a todos nuestros 
religiosas que han sido curas en las provincias de Cotabambas y Omasuyos las lamentaciones con que sus miserables havitadores se despiden para ir a las mitas, como gente que se aparta para morir. Y quántos teniendo por más penosa muerte la de este viage que la natural han amanecido, este colgado de un árbol y aquel despeñado a un río?. Quien no lamenta la desolación total destos pueblos?. La de S. Agustín de Cotabambas donde como en una gran ciudad los oficios mecánicos no se contavan por tiendas si no por calles, una de plateros, de carpinteros otra y así de los demás oficios $Y$ oy apenas ay una india que traiga bara de alcalde. Buena regla para msdir lo que en las demó́s Provincias sucede y lo que en breve acontecerá en todo el reyno. Tenemos por cierto que sin muchos y graves pecados no se puede tolerar esta mita y por más cierto que no cede en utilidad de la hacienda real sino antes en daño suyo; que de excusarla no cesarán las labores de las minas, lo prueba con evidencia la experiencia que en otros minerales que no la tienen: quando ay metales, abundan indios, Conchucos; quando florecía la mina, Chocalla, Chichas y Lipes, Nuevo Potosí, Carangas, Puno y otros muchos son testigos de esta verdad, Con que este dilema parece irrefragable. O tiene Potosí metales $\mathrm{O}$ no. Si los tiene, como de diferentes y distantes provincias acuden voluntariamente $\alpha$ otros minerales y aun al mismo Potosí, más fácilmente a este que tiene avecindados tantos indios. Si no los tiene: inútil y vano es tanto trabajo. Este es nuestro sentir y $\alpha$ lo que tenemos entendido y oído varias veces también es parecer de todos los mineros que no lo son en Potosí. Quiera Dios que el santo celo de V.E. tan experimentado en este reyno tenga el efecto que juzgamos ha de ser de su mayor gloria y descargo de la real conciencia, como continuamente lo deseamos Y pedimos en nuestros sacrificios. De este convento grande de S. Augustín de los Reyes, 22 de Julio de 1670 años. - Siervos y Capellanes de V.E. Fr. Nicolós de Ulloa, Prior y Vicario Provincial.- Fr. Manuel de Valverde, Diffinidor. - Fr. Nicolás de Herrera, Visitador.- Fr. Ignacio de la Breña, Visitador.- Fr. Francisco de Herrera.- Fr. Pedro de Tovar \&\&. 
Parecer del P. Manuel Toledo y Leiva, Rector del Colegio de la Compañía de Jesús de Huancavelica sobre la Mita de Potosí, a petición del Sr. D.D. José Santiago Concha. Oidor de Lima y Gobernador de Fuancavelica, en virtud de R.C. expedida en Madrid el 6 de Diciembre de 1719.

Manuel de Toledo y Leiva, Rector del Colegio de la Compañía de Jesús de la villa de Guancavelica, Cathedrático de Prima de Sagrada Theología ontes en la Real Universidad de San Francisco Xavier de La Plata y después en el Colegio Máximo de San Pablo de Lima y Examinador Sinodal en el Arzobispado de La Plata y en los Obispados de La Paz y Guamanga, he visto por orden del Sr. Dr. Dn. José Santiago Concha, Marqués de Casa Concha, Cavallero del Orden de Calatrava, Oídor de la Real Audiencia de Lima y actualmente Governador de la villa de Guancavelica una Cédula del Rey N.S. (que Dios prospere por muchos años) expedida en Madrid a 6 de Diciembre de 1719 años en que manda S.M. que se consulte con hombres prácticos y que miren únicamente a Dios la materia gravíssima de si es conveniente que se continúe la mita de indios forzados para que trabajen en la saca de metales así de azogues en Guancavelica como de plata en Potosí o no: punto que a muchos años fatiga hombres doctos y píos así de una parte como de otra y que aora en dha. Cédula sucita S.M. con deseo de resolver últimamente lo más conveniente $\alpha$ su Real conciencia y a la libertad de los indios que tanto encomiendan nuestros Monarcas en repetidas cédulas y leyes siendo su piadoso empeño desde la Conquista y posesión destos Reynos dexar en su libertad a los indios como dize el Sr. D. Juan de Solórzano en su Política Indiona, Lib. 2, Cap. 5.

2 Y obedeciendo a lo que su Señoría me intima de que como experimentado en este Reyno dé mi parecer sobre este punto, tomo la pluma deseoso de resolverlo dentro de los límites que alcanzo por lo que he visto en Potosí, Guancavelica y otros lugares que he andado del Reyno y con la luz que las noticias del me dan. Y para proceder con claridad en esta resolución la dividiré en 3 clorses o capítulos, declarando en el primero los fundormentos que ay para que los indios no miten; en el segundo las razones que ay para que miten; en el tercero mi juizio y sentir que será estrivando en las razones de los dos primeros capítulos. Protesto que en este trabajo que emprendo con gusto, miro únicamente a Dios sin passión ni motivo humano, atendiendo a su mayor gloria y en esta a los infelices indios que, como tan desvalidos, hallan su sombra y amparo en la Compañía de Ths. y ellos nos reconocen por sus defensores assi por lo que experimentan en este reyno como porque su último monarcha Felipe que fué degollado en el Cuzco, estando ya en público cadahalso y rodeado de innumerables indios que seguían en aquella lástima a su antiguo Príncipe, antes de rendir la vida al rigor del cuchillo, les dixo con voz alta y sensible que atendiesen con especial amor a los PP. de la Compañía porque en ellos avía tenido en aquel último trance verdaderos amigos y padres y en prosecución de este encargo nos an mirado siempre los indios con igual veneración y confianza. 


\section{Capítulo 1:-En que se defiende que no es conveniente que se continúe la mita o tanda de indios forzados y que es bien dexarlos en su libertad y que la saca de metales sea can indios voluntarios $y$ que espontóneamente concurran $\alpha$ ella, pagados como en otros Minerales.}

3 Prescindo de si es lícita o no en conciencia la mita de que trataré después y sólo me hago cargo de que no ay necesidad de dichas mitas con la paridad urgente de otros minerales del Reyno que tocamos con las manos. Es cierto que en Oruro, Lipez, San Antonio de Esquilache, Lucanas y otros minerales de oro y plata es mucha la saca de metales, siendo en años inmediatos a este la mayor porción que dellas se logra en este Reyno el cerro de Oruro, pues por lo que se avía cerrado la puerta en el de Potosí con la esterilidad de metales ha abierto Dios la de su providencia en Oruro para que de allí salgan ríos de plata con que se inunden assí este Reyno como los de la Europa, llegando a enríquezer tanto a Francia en años pasados que se vió esta Monarchia en la mayor opulencia que jamás se avía visto y esto debido en lo más a la villa de Oruro. Es así que allí no han trabajado nunca con mita de indios forzados ni avrá quien diga que ay mita de indios para Oruro, luego las demás minas se pueden trabajar sin mitas. Argumento es este que más de una vez lo he hecho a hombres no sólo entendidos en lo especulativo sino también a mineros prácticos que no me han dado salida que me convenza a la razón.

4 El mesmo pudiera hazer a semejanza de los minerales de México, Chile Popayan y otros lugares de donde es grande la copia que se saca de oro y plata sin que sea necesaria la mita de indios. Y por esto el Sr. Conde de la Monclova que pasó de Virrey de México a serio del Perú, aviendo oído la voz mita de indios y su significado, la extrañó notablemente, viendo que el Perú costeava la saca de metales con tanta violencia de los indios quando en el Reyno de México jamás avía oído cosa semejante. Y escriviendo a S.M. En carta de $1^{\circ}$ de Enero de 1690 sobre esta materia apuró la inconsecuencia del modo de trabajar en ambos reynos, significando a S.M. quan difícil y contra razón le avía parecido esta fuerza de los indios en el Perú, quando sin ella era tanta la saca de metales en México que era bastante para costear las flotas cada dos años y hacer tantas remisiones de plata a S.M. en ellas que no embía el Perú con todas sus mitas.

5 La qual razón ha movido a muchos héroes grandes de las Audiencias de este Reyno para pedir en tiempos pasados a S.M. que del todo quitase dichas mitas. Y para que se vea palmariamente quan poderosa es, reconózcase el efecto de lo que dan las minas de Potosí y las demás del Reyno. Del cerro de Potosí en años inmediatos a este (como consta del resumen de lo que fructifica este cerro remitido nuevamente a S.M.), apenas llegaron $2,000,000$ de quintos los que se contribuyeron a S.M. cada año $y$ en los mismos años de los demás minerales 6,000,000 de quintos de oro y plata, sobre lo qual discurro así. En las demás minas se trabaja sin mitas y con estas en Potosí: luego más se fructifica de oro y plata sin mitas que con ellas?. Júntese a esto lo muy deteriorada de metales que se halla en el día la villa de Potosí, pues aquel promontorio de riquezas que ha traído de todo el mundo gente para gozar dellas se a pasado ya a Oruro donde el comercio que vi en esta villa es indeciblemente mayor que el que vi en Potosí y es señal de más plata en Oruro el que todos van a el como a río caudaloso pues menos que no tuviese mayor riqueza que Potosí no volara $\alpha$ él la rabiosa sed 
de los hombres con la codicia $y$ toda esta avenida de plata es $\sin$ mitas $Y$ scio con el trabajo de indios voluntarios.

6 Aquí quisiera argüir a los mineros de Potosí con los mineros de Oruro y de los demás minerales. Es constante que todos los que trabajan la saca de metcles en Potosí y otros minerales son indios: cómo pues se dá tanto mayar fruto de quintos a S.M. sin mitas forzadas y con mitas baja tanto la contribución de los quintos?. No son indios unos y otros?. No son idólatras, mentircsos, ociosos repugnantes al trabajo, como dezis, los indios?. A estos consigue solamente la paga y a aquellos los impele la violencia, luego con las mismas propiedades dan más fruto a S.M. estos y aquellos mucho menos. 7 Diróme alguno lo $1^{\text {\% }}$ que esta mita es importantísima a la Monarchia porque con ella en 159 años, desde el de 1545, hasta el de 1704 han dado un quento y 570 millones de ps. de quintos a S.M. las minas de Potosí y faltando las mitas se echará menos ya que no tanto fruto a lo menos el que corresponde al estado tan débil en que se halla Potosí.

8 Está bien: véase pues estando en flor las minas de Oruro y otros minerales del Reyno quanto darán en otros tantos años. No ay duda que mucho más. Y en estos trabajan con mitas?. No, luego menos se sigue $\alpha$ S.M. con mitas que sin ellas.

9 Y si me replican que faltando la mita de Potosí faltará también aun esta cantidad de los dos millones de quintos cada año, respondo que así como la mita de Potosí no es mita de Oruro, tampoco el que no aya mita en Potosí $\alpha$ de ser ocasión para que no aya plata en Potosí. Ay medio entre no aver mita en Potosí y aver plata allí, que es el que trabajen voluntariamente los indios como trabajan en Oruro.

10 Diróme lo $2^{\circ}$ que los indios son inclinados a las idolatrías, enemigos de lo sagrado y de los españoles, dados al ocio, ladrones y con otros vicios que los hacen dignos de ruina eterna y que por evitarles estos pecados es bien forzarlos al trabajo. Y por eso con los informes que de sus costumbres tienen nuestros reyes manda que no se permita que estén holgazanes, sino ocupados en labores de tierra, en los beneficios de oro, plata, azogue y demás frutos necesarios para las repúblicas del Reyno. $Y$ lo más ponderable es que en Cédula escrita a la Audiencia de México, año de 1555, dize S.M. que se tiene entendido por notorio que los indios de su condición son inclinados a holgar y que ay necesidad que sean compelidos (nótese) y apremiados a trabajar porque de su voluntad no lo harán: luego es conveniente que aya dicha mita en Indias.

11 Estimo la objeción porque me ocasiona representar lo que sobre este punto tengo observado en los indios. $\mathrm{Y}$ para que se vea que esto ha sido con especial reflexión quiero antes dezir los lugares por donde he discurrido de todo el Reyno y lo que he inmorado en ellos. Nací en la ciudad de La Paz donde en mis primeros años experimenté algunors cosas de estos pobres que después con la mayor luz de los años reflictiendo sobre ellas he podido juzgarlas. Embióronme al Cuzco a estudiar facultades de Artes y Theología a la enseñanza y abrigo de los PP. de la Compañía donde con su trato me resolví $\alpha$ ser uno de ellos y recevida la sotana fuí a Lima al noviciado y con. tinuación de los estudios, empleando en aquella corte onze años hasta que ordenado de sacerdote, me asignó la obediencia para la Residencia de Juli, que es doctrina célebre de jesuitas y allí estuve 2 meses. Mandáronme que pasase al Colegio de La Paz y aquí viví leyendo gramática por espacio de 3 años: luego me señalaron para la ciudad de La Plata, donde moré 8 años, yendo desde aquel lugar en este tiempo 4 vezes a Potosí y fué necesario en estos viajes detenerme algunos meses en aquella villa hasta que mis Supe- 
riores me llamaron a Lima y pasando por los lugares más principales del Reyno llegué a Lima y estube allí 4 años: de aquí vine a Guancavelica donde actualmente estoy. Toda esta prolija relación de mis peregrinaciones hago para dezir lo que tengo observado en estos lugares de tanta variedad de indios que he conocido en tan largo espacio de provincias $y$ diversidad de costumbres, aviéndolos manejado no sólo en el exterior sino también en lo interior de sus almas. Sé diestramente las lenguas quichua y aymara que son los dialectos con que se goviernan estas provincias y en los tiempos que me han permitido las tareas que me ha encomendado mi Religión he procurado aplicarme a los ministerios destos infelizes, confesándolos y predicándoles en ambos idiomas, siendo este mi anhelo por lo que el Señor me ha dado a conocer que no ay mayor lucimiento para el cielo que poner $\alpha$ una alma en gracia y en estado de que no otenda $\alpha$ Dios.

12 Lo que he reparado siempre en los indios es que no son lo que tanto se pondera dellos. Son hombres sin cultivo, sin letras, abatidos, humildes $y$ mucho más viéndose tan despreciados de los españoles. De aqui nace comunicar poco a nada con los españoles y ser todo su comercio solo entre ellos. Y qué puede ocasionarles su trato bajo y su ignorancia sino una creencia de supersticiones y agüeros, pues en los hombres blancos sin policía se ven continuamente errores, supersticiones agüeros $\mathrm{y}$ vanas observancias?. Ojalá no fuera este vicio sólo de los indios! Pues no se vieran las librerías Llenas de ejemplos y doctrina contra las supersticiones que tanto dieron que hazer a los Sagrados Tribunales de la Inquisición, aun antes que se descubriesen las Indias. Fuera de que los indios no son tenaces en ellas porque aprehenden vivamente lo que se les predica y quando su párroco o sacerdote les propone lo malo de sus opiniones se desvían dellas procurando dar crédito a lo que se les exhorta.

13 En todos estos casos que he discurrido por tan varios lugares ha confesado a innumerables indios y manejado ya se vé quantos. $Y$ puedo asegurar como christiano y sacerdote que en lo que les he oído jamás he encontrado en ellos el pecado de idolatría, antes he advertido su constancia en creer en el verdadero Dios y en los misterios de nuestra católica fe. Pues qué idolatría es esta de estos pobres indios?. Si acaso la ay en los nuevamente convertidos no la extrañaré porque acaban de salir de ella y es difícil quitarles del todo su falsa fe. No he estado en misiones de gentiles y así dellas no tengo experiencia, pero si mucha noticia de nuestras conversiones de Moxos, donde en los pueblos de cristianos nuevos está la fe tan pura que en el día del juicio an de ser verdugos para el tormento de los cristianos antiguos. Velen los sacerdotes y curas con la continua predicación, castiguen $\alpha$ los que delinquen en esta materia y verón cómo está la fe y la divina ley en los indios.

14 No son enemigos de la Iglesia sino todo lo contrario, porque lo que he visto en todo cuanto he andado es que los indios son muy amantes de lo sagrado. No entran en templo donde no hagan más reverencia al Señor y a los Santos que otros que tanto se precian de cristianos. Si fueran enemigos de la Iglesia no se vieran tantos indios oyendo misa en días ordinarios y que no son de precepto. Asómbrame lo que he observado en estos pobres. Quienes fomentan más el culto divino en estas tierras de arriba que los indios?. Todo el año están trabajando para sus fiestas. Quienes costean con más decencia las fiestas del Corpus y procesiones de Semana Santa sino los indios?. El que viere los Colegios de la Compañía de Jesús en Potosí, Poz, Cuzco, Plata, Oruro, Juli, Guancavelica y otros tan trequentados de sacramentos en días 
de jubileo de N. Señor de su Sma. Madre y otros repare que los indios son los que confiesan y comulgan más. Si tocan a sermón y hazen señal para fiestas acuden los indios a bandadas a oír el sermón y asistir a la fiesta. Desto pudiera decir mucho más porque lo he tocado con la experiencia.

15 Dirá la objeción que son flojos, vagabundos y dados al ocio los indios. Y pregunto en qué está la ociosidad de estos miserables?. Así se desacredito un gremio tan crecido de la cristiandad y el orbe?. Abra los ojos y vea quien lo dize lo que sucede en el Perú. Sacadas las poblaciones principales de las costas del mar, donde sirven muchos negros, mulatos, zambos, quarterones $Y$ mestizos, en todo el reyno los indios son de todo el trabajo. No ay mercado en todo él, que los indios no lo formen. Ellos en Lima son los pescadores y los que la dan la grande abundancia que tiene de peces por Ias calles y plazas. Ellos llevan a las ciudades, villas y pueblos las comidas ellos cultivan las chacras, acarrean el trigo, el vino, el aceite, las carnes; ellos son pastores y guardas de innumerables estancias que ay en el reyno repechan cordilleras para servirnos; penetran valles muy ardientes para nuestros alivios; viven como austerísimos hermitaños en unos desiertos in. habitables, sin sueño, sin más alimento que unas raíces y un poco de maíz sin probar carne casi en todo un año, expuestos al yelo, al sol y a las agua., rayos y fríos, sin más defensa que un pellejo por colchón y una frazada raída por cubierta, padeciendo todos estos rigores por dornos de comer. Los oficiales para todo género de oficios mecánicos son casi todos indios y estos nos visten y nos proveen de lo necesario para la decencia. Sólo en el Cuzco pasan de 12,000 los oficiales de todo género de oficios y casi todos están en poder de los indios. Quienes han fabricado las ciudades, villas y pueblos de la sierra sino los indios?. Los suntuosos templos del Cuzco, Plata, Potosí, Paz, Juli y aun de Lima y los muchos que ay en el Perú, a quienes an tenido por artífices en la mayor parte sino a los indios?. Quienes componen los puentes, los caminos, allanan los montes y rompen las selvas sino los indios?. Y estos son ociosos, estos flojos, estos vagabundos?.

16 Díganme los que quieren $\alpha$ los indios por sus esclavos, en qué consiste la ociosidad de estos desdichados?. Qué más han de hacer en su servicio que lo que hacen?. Vayan a Turquía y vean si hacen más los cautivos christianos en obsequio de los mahometanos que los indios en beneficio de los españoles. Ellos, por servirlos, velan, duermen con incomodidad, comen mal $y$ muchas veces son aoztados de los españoles, apaleados y tratados con injurias, mós como brutos que hombres y como cristianos. Esta es ociosidad. Esta es flojera?. No lo es que no los sirvon con la puntualidad, limpieza y exacción que quisieran porque son hombres cortos, tímidos, pobres, desaseados y débiles en fuerzas. Es por ventura flojedad que los caballeros alimentados con manjares regalados y exquisitos no hagan?. A la labor de las minas, a los oficios mecónicos de peso y fatiga?. No, por cierto; pues para que no sean tenidos por flojos tienen sus empleos correspondientes a sus personas. Lo mismo digo, proportione servata de los indios; estos por su naturaleza y ningún regalo $\mathrm{y}$ aquellos por lo muy bien comidos son débiles. $Y$ por eso nuestro gran Dios que dispuso las providencias de las cosas con grande sabiduría, les dió a estos miserables para su manejo animales proporcionados $\alpha$ su debilidad: no les dió elefantes, camellos ni otros que piden más brio para su uso; dióles llamas o carneros de la tierra, animales por si de pocas fuerzas que caminon y cargan poco. No les dió viñas, olivares que son de alguna fatiga sino chácaras de maíz $\mathrm{y}$ de otras raíces que son de menor costo. 
17 Y así creo que esta fama de que los indios son flojos nace de verlos débiles y sin aliento para cosas pesadas y de sumo trabajo. Las chácaras que tienen son para ellos muy costosas y así en un palmo que tienen de tieIras gastan todo el año como pobres en cultivarlo y para esto se ayudan unos a otros los vecinos y parientes y como el tiempo de la primavera y estío están guardando sus sementeras y no tienen que labrar, se lleban la fama de ociosos. Como si el mercader que está sin vender en su tienda esperando compradores no estuviese ocioso y si este no lo está porqué el desgraciado indio se ha de llevar estos créditos?. Faltaran los indios del Perú y vieran los españoles como padecían y carecían de todo. Díganlo estos años en que han muerto con la peste tantos millares de indios; qué penuria ha avido de todo; que desoladas han estado sin cultivo las haciendas; los ganados sin pastores; las fábricas y oficios sin artífices; las plazas sin comidas; los animales de servicio y cuidado y todo esto por qué?. Porque han faltado tantos indios: luego si estos ministerios se hacían con el auxilio de los indios, cómo son flojos, cómo inútiles, cómo vagabundos?.

18 No extrañaré que sean enemigos de los españoles porque el trato que tienen $\alpha$ ellos no es para otra cosa. Pero aun esto no es del todo verdad porque al español que los farorece y mira con agrado, lo buscan, lo regalon y sirven, exponiéndose para socorrerlo a los ríos y mayores incomodidades. Si hallan buena correspondencia en el español, con él son sus tratos, sus confianzas y comercio. $Y$ desto tengo experiencia desde mis primeros años.

19 Dice la objeción que son mentirosos. No fueran tán mal vistos y no se les diera tan en rostro con vicio que es tan trascendental en hombres y parece que sigue al pecado original que heredamos de nuestros primeros padres que con la mentira se introdujo el pecado y la mentira es la balanza con que todo lo pesan los hijos de Adán: mendaces filii hominum in stateris (Salmo 61) Omnis homo mendax (Salmo 156). Y siendo propia de gente baja la mentira, qué mucho reine en los indios pues son de condición tan abatida?. Fuera de que ay indios de tanta verdad como el más noble español. Que sean ladrones no es igualmente cierto en todos ellos. Hurtos ay en todas partes, salteadores de caminos y que no respetan para su malicia a lo sagrado, pero qué hurtos son los de los indios?. Rateros muchos y las más veces de cosas bien tenues. Fuera de quien reflictiere en la suma seguridad que ay en el Perú verá que los ladrones no son los indios. La mucha seguridad en los caminos sin que aya quien destos se atreva, sino rara vez, a los pasajeros que llevan al ordinario muy gruesos caudales es señal que los indios no son ladrones, con ser que estos son los que habitan los más de los lugares vecinos a los caminos. En las casas de los hombres ricos y españoles tienen el cargo de cuidar la plata labrada los indios y la guardian tan exactamente que entregan las mesmas piezas que les dieron sin menoscabo alguno. Los ladrones son los mestizos, zambos, negros $y$, a veces, los más preciados de hidalgos, echando la culpa de sus robos a los indios. Es cosa rara la que tengo notada en los pueblos y ranchos de indios que sus casas no tienen llaves de fierro y quando quieren esconderlas cierran las puertas con un montón de piedras ó si tienen puertas atan contra la pared las puertas y a veces un pellejo y con esta diligencia quedan muy seguras sus casas, aunque se ausenten a distancias $\mathrm{y}$ por mucho tiempo. $\mathrm{Y}$ si fueran ladrones no tuvieran tan poco resguardo y tuvieran mas cautelas sin que viviesen tan confiados de que no les hon de robar como sucede. Si alguna vez han cogido en hurtos a los indios no es bastante para que todo el gremio de indios sea de ladrones como el que en algunas partes aya desórdenes entre pocos es bastante para comprender en ellos a toda una provincia o reyno. 
20 La embriaguez es el vicio más común entre indios y esto sucede quamdo tienen fiestas, entierros, casamientos y otras cosas semejantes pero ésta Ia puede quitar la vigilancia de los curas y Corregidores, pero como no hazen caso della ni la quitan prosiguen estos infelices con sus vicios de beber sin que hagan juicio dellos. Estos son los defectos que imputan a estos desgraciados hombres quienes más podían defenderlos, por ser sus criados, sus benefactores y aun esclavos. Así les pagan sus sudores por servirlos: pero, qué ha de dar el hombre sino ingratitudes، pues de Dios se queja y acusa tal vez su providencia?.

21 Pero doy que tengan estos y más vicios los indios; por eso se han de condenar a una pena tan horrenda como es la mita?. Si los hallan delincuentes en semejantes delitos, está bien: porque la culpa es justo que se castigue, pero porque son inclinados a idolatrías, $\alpha$ hurtos, al ocio, a la embriaguez, han de padecer castigo tan cruel?. Ardua cosa es y que no cabe suceda entre cristianos! Para no delinquir contra la ley de Dios, al que contra ella se incline, ay medios en la Iglesia, estos son las oraciones al Señor, las exhortaciones de los sacerdotes, la predicación frecuente de los curas y pastores de las almas. Pero si los curas no los exhortan, no les predican, sin que se les oiga un sermón moral entre año, conforme a lo que monda el Concilio, qué he de decir sino antes que es milagro de Dios no se vean cada día muertes y cosas semejantes en los indios?. Mas qué bondad suya es, sin cultivo ni estímulo para el bien, ver que vivan tan cristianamente y con más temor de Dios que los que son mas antiguos en la fe de Jesucristo?. 22 Sobre este último punto quisiera que mis lágrimas fuesen voces vivas para decir a nuestro Católico Monarca lo que se experimenta en este Perú. Señor, V.M. desde su solio manda santísimamente que sean estos indios atendidos de los curas, pero vemos los que estamos a los pies de vuestro real trono en estas remotas regiones todo lo contrario. Cómo han de instruir, predicar y alentar $\alpha$ la virtud a estos pobres indios, quando muchos de los curas no saben su idioma? Tiene medios Dios y uno dellos es la frecuente predicación de los ministros del evangelio, siendo estos de obligación los curas. $Y$ cuantos curas no saben qué es subir a sus púlpitos ni sentarse en los confesionarios para bien de sus feligreses?. Cómo pueden instruirlos en la ley de Dios cuando no saben su lengua?. No ay para los curas más que zelar les paguen derechos y esto con un ardimiento tan grande que si fuera zelo de la guarda de la ley de Dios menos culpas se hicieran y quizá no fueran tan reparados de los seglares los curas. Este punto trataré después en el último capítulo. 23 Y no me desvío de la queja a S.M. del olvido tan grande que tienen destos desdichados sus ministros, alentóndome para representar a S.M. lo mucho que su real zelo encarga en tantas cédulas el cuidado de los indios. enterneciendo los corazones más de diamante lo que N.S. y Rey Felioe V exemplo de religiosos y de los que mós horn despreciado el mundo, con la renuncia de la corona en la flor de sus años, escribe desde el monasterio de S. Ildefonso al Sr. D. Luis Fernando, su hijo, Príncipe entonces de Asturias y oy nuestro Monarca y Señor. Entre otros encargos que hace a S.M. para el buen gobierno de la Monarquía le pide que mire mucho por los indios, como que en su piadoso pecho vive para la lástima el amor destos pobres. Qué dijera S.M. si viera que muchos o los más de los Corregidores del Perú tienen sojuzgados a los indios para la tiranía?. No ay justicia para estos miserables: no $\alpha y$ corrección amorosa ni se cuida de que guarden la ley de Dios. Pora un Corregidor toda la justicia se endereza a que paguen los indios lo que les deven: $\alpha$ fin de esto son las cárceles, los azotes, los grillos y cadenas, siendo peores que Nerón y Diocleciano para inventar nuevos tormentos 
y cárceles para castigar a los que les deben. Corregidor he visto que para los que le devían fabricó una córcel tan estrecha que no cabía en ella más que un hombre en pie y así los tenía mucho tiempo con los brazos suspensos hasta que pagasen o hallasen fiadores que $\alpha$ vista de aquel tormento se moviesen a serlo. Corregidor o Juez a avido que, aviendo muerto un indio que le debió en vida, porque le debió en vida lo tuvo después de muerto colgado en la plaza corrompiéndose hasta que uvo quienes con más piadosas entrañas se ofrecieron a pagar la dita, porque lo quitase de allí y diese sepultura eclesiástica. Y los demás delitos se castigan?. Se advierten a los indios?. No. Y es más que docilidad y firmeza en la fe a vista destos ejemplares no retirarse los indios a tierras de gentiles, donde quizá no vieran tan. tas inhumanidades que experimentan de los corregidores.

24 Lastima los corazones católicos saber que los indios gentiles del reino de Chile y muchos paganos de las vecindades del Perú no admiten la fe católica que se les predica, porque temen que siendo cristianos los sujeten a las mismas pensiones que a los ya convertidos los españoles. $Y$ a la verdad si menos motivo harce renegar de Dios a tantos católicos antiguos de sobrado entendimiento y virtud que son cautivos en Turquía y que de las vanderas de la Iglesia se pasan a las de Mahoma, más que milagro es que el Perú no se despueble y se vayan los indios a la vanda de los gentiles, que tơn vecinos estón deste Reyno con tanta violencia de corregidores Y españoles.

25 Dije por último la objeción que los indios son dados a todos vicios $Y$ no hago mención de tantas obras buenas que tienen. Los vicios todos de los indios se reducen $\alpha$ embriaguez y supersticiones, pero qué otros se les conocen?. El desorden con mujeres no es tanto como se pondera. Diré para defensa desto lo que me aseguró un cura de indios y de españoles que en los libros que tiene de bautismos, raro es el niño indio ilegítimo y los más ilegítimos son mestizos, cuarterones y de otras castas. Las buenas obras que tienen estos miserables son de grande caridad con los forasteros indios, hospedóndolos en sus casas y regalándolos en el modo que pueden. No ay pobre que llegue a sus casas que no sea socomido. Los conventos que viven de limosna son el socorro de los indios. Tienen grande piedad con las almas del purgatorio y de sus parientes y conocidos; pues la mayor porción de misas que dicen los sacerdotes por el estipendio que reciben de los indios y para hacer decir misas se quitan el sustento, guardando un real hasta llegar a juntar lo suficiente para una misa. Ellos mandan decir misas por los SS. Obispos difuntos, por los sacerdotes, por los ahorcados, por los que mueren en despoblado. Ellos recogen la mayor limosna que se recoge en la sierra para las ánimas del purgatorio, para los cristianos cautivos. Ellos gastan sus medios reales en comprar flores para los altares de los Santos y los mantienen todo el año en adorno. Ellos, por último, han de ser mi confusión el día del tremendo juicio de Dios, pues con menos noticia de las cosas de Dios y de la eternidad son tan buenos y yo, siendo sacerdote, religioso y jesuito $\&$. No lo puedo decir sin sobresalto de que Dios me ha de hacer horrendo cargo en su tribunal. Pero quizá me favorecerá su misericordia por la verdad que aquí digo para defensa destos infelices.

26 Y pasando $\alpha$ responder directamente a la objeción del núm. 10 digo que a los primeros obices queda bastontemente satisfecho en lo que hasta y que es así. A lo $2^{\circ}$ que por evitarles la eterna ruina será bien que trabajen en las mitas, respondo que esto no es evitarles la ruina eterna sino hacer que los indios y españoles se condenen y avrá más número de infelices en el infierno: porque los españoles que cometen tontas tironías, tantas injus- 
ticias y robos con ocasión de las mitas se condenon por ellas. Los indios que ven su mal ejemplo se alientan con el a mayores pecados y obligados de los injustos pechos de los españoles, para satisfacer a ellos maquinan. hurtos, drogas y otros delitos. Más, viendo los indios que en las villas y minerales viven tan escandalosamente siendo cristianos toman aliento para hacer lo mismo y peores cosas en sus tierras. Vean los mineros celosos de la salvación de los indios si el salvarse está solo en trabajar forzadamente en las minas y vean primero por sus almas, cómo están más cerca de condenarse que los indios y con mayor infierno, pues tienen más conocimiento de las cosas de la veternidad que estos desdichados.

$27 \quad A$ lo $3^{\circ}$ de la objeción de la cédula de $S . M$. respondo que lo que $S$. M. manda es que fuerzen a los indios a trabajar, suponiendo que son holgazanes. Lo $1^{\circ}$ la suposición queda vencida desde el núm. 15 porque tienen hecho un informe de fama solamente a S.M. y no de realidad, la qual para que se conozca es menester que la vean hombres desinteresados, sin pasión y con conocimiento cabal de lo que sucede con los indios. Lo $2^{\circ}$ lo: que manda S.M. es que a los indios se fuerze el que trabajen en sus haziendas y oficios propios dellos y que, dado caso que laboren en las de los españoles, sea con gusto, elección de amor dellos mismos y otros medios que santa y piadosamente dispone S.M. en favor destos pobres y se puede ver altamente en el citado Sr. Solórzano ubi supra. Y así su mente real es que no dejen ociosos a los indios pero que la fuerza sea sin violencia y sin detrimento de su libertad.

28 Diróme lo $3^{\text {o }}$ alguno que de que pongan a trabajar forzadamente las minas se siguen muchos provechos de los indios. Lo primero, que saigan a tierra donde ay frecuencia de sacramentos, misas, acciones devotas y guarda de los mandamientos de la Iglesia, todo lo cual no logran en sus tierras, retirados de todo esto y por eso con muy poco conocimiento de Dios. Lo $2^{\circ}$ que con las pagas que reciven de su trabajo se hazen menos pobres y tienen de qué echar mano para sus necesidades y menesteres.

29 Resp. Niego el antecedente porque aunque de que trabajaran en las minas se siguieran estos bienes, no precisamente de que vienen forzados, pues viniendo voluntarios lograrón mejor estos tan grandes provechos, los quales quizá no los consiguieran viniendo precisados, porque hallándose forzados, con la impaciencia de bolverse a sus casas y familias y con el sumo trabajo de las minas sintieran mal de todo lo que viesen. Demás que los lugares de donde salen a mitar los indios no son tierras de gentiles sino pueblos cristianos, donde ay culto divino, sacerdotes y párroco cuya obligación es instruirlos en la fe y doctrina cristiona y quando más hacen tránsito de pueblo a pueblo donde son los ritos eclesiásticos de enseñanza los mesmos y lo que no los aficionó en sus pueblos propios no los ha de mover en los ajenos, si ellos por si no son bien inclinados y devotos. Y ojalá no saliesen de sus pueblos a los de los españoles, para que viviese en ellos con más sinceridad la fe católica y no la turbase el mal ejemplo destos con lo que ven y no dijeran lo que tal vez les he oído a los indios: que cómo siendo españoles y de tanta obligación para guardar la ley de Dios la quebrantan tan descaradamente.

30 Ni es razón que con las pagas de lo que trabajan se hazen ricos y salen de su pobreza, porque aunque es verdad que les acrece la plata, pero viéndose en tierras más abundantes de aguardiente, vino y chicha, so dan con más libertad a la embriaguez y a otras maldades que son hijas de la abundancia. He reparado en Potosí que los Domingos que son los días en que bajan del cerro los indios es muchísimo el consumo de chicha en la plaza 
Y cómo andan caídos por los suelos con la borrachera y fuera de sí. Y quando estos pobres han de comer entre semana y han de comprar velas, porque muchas veces no son bastantes las que les dan sus amos, poco les puede quedar al cabo de la semana de lo que reciben de sus jornales. Muy contentos estón en sus tierras porque no son tan dejados que no hagan sus viajes a los valles por comidas y a otros lugares que abundan dellas y así he advertido en las ciudades y lugares en que he morado que, pasada la cuaresma, se van los indios a las cosechas y están en ellas 2 o 3 meses así para ayudar a coger los frutos y lograr con su trabajo comida o para mantenerse en sus tierros como para comprarlas en que la utilidad que tanto se pondera les viene de las minas no es como se juzga.

31 Diráme finalmente, que así como recuperar una ciudad con hacer que salgan a batalla los vecinos de otra ciudad o Provincia, compelidos para ello de su Príncipe es lícito y conveniente, aun dado que mueran en la refriega millares, también será lícito y conveniente que sean compelidos los indios a trabajar en las minas, aun dado que mueran algunos en la demanda. Y la razón de la paridad es porque las minas valen más que una ciudad y más las de Potosí y Guancavelica que son la arca del tesoro de nuestro Rey Y Señor y así como una ciudad cede $a$ su honor, utilidad e imperio también y con más razón lo son las minas del Perú.

32 Respondo que quando ay soldados bastantes para restaurar una ciudad y que voluntariamente sin violencia puedan salir a recuperarla, no ay necesidad de que sean forzadas otras ciudades o provincias para ganarla. Y así también digo de las minas que quando a tantas minas que cito en las pruebas es constante que concurren voluntariamente $y$ sin fuerza los indios, movidos del cebo de la paga, dando tan considerable fruto a S.M. no ay necesidad de que trabajen compelidos ni con la violencia que se experimentan. 33 Estos son los capítulos que he hallado objecionar a los que con tanta acrimonia defienden que es necesaria la mita de indios para la labor de las minas del reyno. A que me parece satisfago plenamente con la verdad que tengo esperimentada y no de paso y sólo por noticia sino muy de propósito y advertidamente, porque tengo muy bien visto el reyno. $Y$ lo mismo creo que dirán otros muchos que saben lo que pasa en él con los indios, que cunque son de poco ánimo, cobardes y tímidos, son hombres que conocen el bien y el mal y por eso aman su provecho y aborrecen su daño y quando viniendo voluntarios a las minas pueden hallar su utilidad, como diré después, les fuera muy llevadero trabajarlas con menos carga y con más alivio.

34 Qué dijeran nuestros Monarcas tan benignos y suaves, principalmente con los indios, si vieran por sus ojos lo que, tocamos con los nuestros en estos reynos, viendo a estos desgraciados quánto padecen por dar utilidad a los españoles. Y así estoy muy cierto que las minas tienen pobladas los infiernos porque con ellas crece más cada día la codicia y con la codicia cuántas maldades pueden imaginarse, pues de todas es raiz la codicia. Muchas veces son las que se experimentan con la fuerza de las mitas, porque para lo voluntario ay ruego del minero y puntualidad en la paga, temiendo que con su mala paga no vuelvan los indios o sabiendo los demás su maltrato se les retiren y se hallen sin indios para la saca y beneficio de sus metales. Al contrario, cierto el minero de que no le han de faltar indios forzados, les paga mal, les trampea su estipendio o lo dan como quieren, ya en géneros que valen menos de lo que les dan a los mitayos ó del todo no les pagan, llevando delante la droga con paliaciones y promesas para después que nunca llega.

35 Y por eso conociendo estas mitas en el estado en que oy están no sé 
qué dijera D. Francisco de Toledo que la impuso, si resucitase: fuese a España y se fué con el gusto de averlas impuesto sin averlas llegado a ver en el suceso, lo que han causado después y lo que se experimenta. Y el señor D. Fr. Jerónimo de Loaiza, Arzobispo que fué de Lima y el P. Fr. Miguel de Agia, franciscano, que le dieron dictamen para esta mita, viendo con el tiempo lo que ocasionaba, sintieron muchísimo después averlo dado y se retractaron a la hora de la muerte, pidiendo que se representase así a S.M. El Virrey que empezó la mita de Guancavelica, estando para morir, ya en los últimos paroxismos, tuvo a los ojos innumerables indios que como átomos del aire se le ponían delante, atormentando tanto su vista que con voz clara y sensible que oyeron los circunstantes, dijo: Dejadme, indios de Guancavelica, qué queréis y contó luego lo que le pasaba. Y si la hora de la muerte Y el juicio de Dios son el espejo donde se miran las obras de toda la vida, qué verán entonces los mineros, los corregidores y jueces que tanto insisten en esta mita con tanta violencia de los desdichadísimos indios?. Allá en la eternidad se sabrán las cosas desta mita que tanto las palia la codicia en vida. Menos pecados hubiera, decía un entendido, si el cerro de Guancavelica se fuese a los infiernos; pero el trabajo es que, siendo escuela de tantas maldades, es puerta muy abierta para el infierno. Pásemos ya al capítulo siguiente.

\section{Corpítulo $2^{\circ}-$ En que se defiende que es conveniente horya mita de indios que trabajen forzados.}

36 Muchas son las razones que han dado varones santos, doctos y experimentados para que se continúe la mita de indios en la labranza de las minas del Perú, las cuales he visto en pareceres nuevos que se han dado y en la Política Indiana de D. Juan de Solórzano (Lib. 2, cap. 6), y se reducen a las que tengo puestas por objeciones en el Cap. antecedente y muchas otras que omito porque son especulaciones y no más y que fácilmente se responden con todo lo que tengo dicho.

37 La razón principal que yo hallo para que la mita prosiga es que si se quita es también quitar toda la riqueza del Perú. Hablo de la mita de Guan. cavelica que debe ser oy el mayor cuidado de S.M: como que es la fuente de todo el tesoro de la Monarquía. La razón de mi proposición es: 1--Porque quitóndose la mita se pone en duda de si avró indios voluntarios que la trabajen y pónese a riesgo de que no lo aya y lo más cierto es que no los avrá. Porque los indios que la mitan, la miran con especial horror, saben lo labo. rioso que es y por eso cuesta mucho el reducirlos a que vengan, de manera que por no venir a Guancavelica y trabajar en el cerro quieren más aína pagar más cantidad de la que lograrán si trabajasen. Júntese $\alpha$ esto que pa. ra reducirlos a que crear que ya no ay mita para Guancavelica y que es voluntario trabajar en ella, fuera (menester) mucho tiempo de experiencia y en este apenas hubiera indio que trabajase mientras se enteraban de la ver. dad de que no ay mita.

38 La $2^{\text {q }}$ razón es que los indios destas tierras son más dejativos y por eso menos inclinados al trabajo y más a trabajo tan grande como el del azogue. $Y$ esto se funda así en la experiencia de que se huyen por momentos del cerro como en que tienen muy cerca la gentilidad y por huir deste trabajo se pasan muchos allá, dejando sus tierras por evitar la fatiga. Y por eso es menester forzarlos para que vengan a la mita de Guancavelica.

39 La $3^{\text {qu}}$ que dó el P. Acosta (De Procuranda Indorum Salute, Lib. 3, cap. 17) que, aunque la contraria opinión parece fácil, honesta y piadosa, en queriendo reducirla a próctica es muy difícil y llena de inconvenientes. Y fué 
el P. Acosta un hombre muy versado en las Indias y reconoció prólíjamente sus naturales, costumbres y estado, aviendo sido Visitador de la Provincia do México y del Perú (1) y quando escrivió este libro bien tenía visto lo que pasa en ambos reynos, así de México como del Perú y con todo eso, siendo tan santo, piadoso, amante de los indios y docto como fué, resolvió que era bien que se continuase la dicha mita. Y qué dijera viendo los gravísimos inconvenientes que oy se hallan para que aun con indios forzados trabaje?. Porque con la mortandad de indios que ha avido en 8 años de peste en este reyno son las poblaciones despobladas, quedando las casas solo por monumentos, donde la lástima oye que allí fué Troya, arruinadas las estancias, desiertos los pueblos y sin cultivo, por falta de indios las haciendas, pues han muerto ( $y$ no cesa la peste) más de 150,000 indios en todo el Perú. Y si quanto abundaban tanto los indios fué siampre árduo reducirlos a Guancorvelica, qué será oy y qué fuera si se quitase la mita, con ianta falta dellos?. De aquí nace que toda la actividad de S.M. que suma en poner mitayos y jornaleros en el cerro, se halla sin saber qué hacerse, sin que muchas visces le baste para conseguirlos escrivir a los Corregidores para que embíen indios, hacer despachos de soldados que los recojan de las Provincias que deben mitar y aun valerse del auxilio del Sr. Virrey para que con su brazo obligue $a$ los Corregidores y Tenientes para que hagan remisión de indios. Y a no aver esta prolijidad y zelo con que V.S. mira la mina Real pudiera recelar que se menoscabaran mucho los haveres de S.M. y cayera en gran manera el Perú.

40 Ni es bastante la ayuda de los reos para que trabajen en la mina, porque estos son contingentes y pueden con esta pensión huirse al cometer los delitos y no ponerse donde los aprehendan para que vengan al cerro o escaparse deste o suceder algunas fatalidades que ocasionan hombres semejantes. Y por último las prisiones y apremio con que es forzoso que estos trabajen, puede ser ocasión para que los indios como cortos de capacidad se retiren del todo a tierras montuosas y de infidelidad, aprehendiendo que así se trabaja y por no caer en su aprehendida violencia dejar sin remedio $a$ Guancavelica.

41 Esto es por lo que toca a Guancavelica, porque este es el único mineral que oy de azogues en las Indias y la única levadura de los metales de oro y plata dellas y así debe cautelarse mucho el que no se quite la snita a Guancavelica. No es así en Potosí porque ay muchos minerales de oro y plata en el reyno y si faltase Potosí no faltaba del todo la riqueza de la Monarquía. Es Potosí lugar muy grande y solo dentro de sus goterasi tiene so, bradamente indios para que trabajen sus minas, como bien lo ponderó a $\mathbf{S}$. M. el Sr. Obispo de La Paz, Fr. Mateo Villafañe, en carta que a S.M. escrivió. Pero Guancavelica es lugar corto, de pocos indios y destos se echa meino para los reparos del cerro y no son bastantes para las tandas y así es menester valerse de las mitas que hazen los pueblos vecinos.

42 No es arbitrio suficiente traser el azogue de Almaden, así por la calidad del que en años pasados probó mal para los metales de Potosí como por las contingencias del mar, porque pueden llegar a faltar y también porque se destruyera del todo Guancavelica, aunque diese algunos quintales de azogue para ayuda de los metales de Almaden. Es una población esta de mucha piedad, culto divino, parroquias, conventos $\mathrm{y}$ hospital, donde se ejercitan virtudes de caridad y religión. Y si era empeño del Sr. D. Felipe III ,mante-

1) El P. Toledo lo llama Visitador pues no lo fué en sentido estricto. Ambos países cor.oció $Y$ visitó y en el Perú ejerció el oficio de Provincial. 
ner las Indias por los templos, aun viendo que nada la tructificaban estas para su remisión a la Corte, es muy propio de la grande cristiandad de nuestro Rey fomentar esta población y sus templos, quando era adorada en ellos la Majestad Divina frecuentados tontos sacramentos y el ejemplo de estas vecindades para la fé.

\section{Capítulo $3^{\circ}$-En que resuelvo que se prosigan las mitas de los indios, quitóndoseles otras pensiones.}

43 He llegado ya al punto que $\alpha$ mi parecer es de grande alivio para la conciencia de S.M. y para el mejor logro de las minas de Guancavelíca porque abrazc los dos primeros capítulos en que tengo defendida la libertad de los indios y juntamente la necesidad que aya mitas en el cerro y cómo parecen opuestas conclusiones, después de averlo pensado muy despacio $y$ encomendado muy de veras $\alpha \mathrm{N}$. Señor para que me alumbre en lo que he de resolver.

44 Digo que es bien que prosiga la mita, pero que a los indios que mitan y trabajan en La Rosa, esto es en los reparos del cerro no se les carguen otras pensiones, conviene a saber, que no paguen tributo a S.M., que los corregidores no les ocupen en sus intereses, como en trabajor en sus obrajes, que los curas del cerro no los graven tanto por los derechos y que aya siempre mucho cuidado (como el que oy ay, gracias a Dios y a la piedad de V.S.), en el Hospital, para que se curen $\mathrm{y}$, por último, se guarden con puntualidad las Ordenanzas que cautelan del bien de los indios.

45 Esta conclusión la tengo por del servicio de S.M. Y logro de sus haveres reales, por piadosa, y que favorece al mismo tiempo la libertad de los infelices indios, que son dignos de toda compasión y lástima. Tiene muchas partes que piden especial prueba y así iré declarando una por una, para que me haga entender y pues hablo con un Sr. Oídor, tan sabio, tan limado en los estilos escolásticos y que me oirá con amor, perdonando mis muchos yerros, procederé con esta forma que conozco es la más proporcionada a la razón.

46 La $1^{\alpha}$ parte, esto es que prosiga la mita, queda probada en toda el cap. $2^{\circ} \mathrm{La} 2^{\alpha} \mathrm{P}$. que parece difícil es que los indios mitayos y los jornaleros que trabajan en La Rosa no paguen tributo a S.M. Y la pruebo así: mita y tributo son dos pensiones gravísimas para los indios y tanto que solo la mita tiene fugitivos a muchos indios, como tengo ponderado en todo el cap. $1^{\circ}$, pues qué será, cuando se les añade el tributo?. Y si estos pobres no pueden con una carga, cómo no se rendirán a dos?. Una cruz quiere el Señor que tengamos todos, tollat crucem suam, y es posible que sobre la cruz horrenda de la mita han de tener otra los indios como la del tributo?. Si viera S.M. lo que los Corregidores y Caciques hazen con los indios por los tributos, creo que desde luego se inclinará su amoroso corazón a lo que digo. Lo mismo es en el pueblo de Juli y las demás provincias inmediatas a La Paz: publícase la mita que luego los jueces y caciques cobran el tributo y como estos van por un año a Potosí, se les pide el tributo anual: con qué violencia?. Dá horror decirlo. quítanles sus vestidos, sus alhajuelas y el poco dinero que tenían para caminar viaje tan dilatado. De que se sigue ir los pobres con grandes incomodidades llevan sus hijos, mujeres y familia, sin más sustento que una talega de maíz que comen ellos y su formilia, auxiliándose para la hámbre con un poco de coca en la boca. Saltánseme las lágrimas al escribir esto y referir lo que ví, yendo desde La Paz a Potosí y entonces me faltaron 
ojos para llorar viendo espectáculo tan tierno. Encontré en el camino unos indios de Juli que venían de aver cumplido su mita, traían a pie sus mujeres y sus hijitos tiernos, unos a las espaldas, otros en unas angarillas con tan poco resguardo del sumo frio que ay en aquellos caminos que iban llorando los angelitos con aquella inclemencia y preguntándoles por su alimento ví que sólo un poco de maíz era este, restóndoles todavía mucha distancia para llegar a su pueblo. Y si esto sucedía quando venían de Potosí, donde avían adquirido sus salorios, cómo irán de sus pueblos a la mita si del todo no se les dan los leguajes que mandan las Ordenanzas les den para la ida Y vuelta?. Y cómo irán si les fuerzan a que paguen los tributos?. Luego tuvieran más alivio y caminarán con más gusto si no fueran con la pensión de tributar.

$47 \quad$ Lo $2^{\circ}$ pruebo esta $2^{\alpha}$ parte. El horror de las minas es tanto que no ay palabras para descifrarlo. Es una mina la más viva imagen del infierno, porque está, 100, 200 y más estados hacia el abismo: sin luz mós que la artificial de velas de sebo y de ichos; allí entan por sendas estrechísimas que $a$ fuerza de combas, picos, barretas y tiros de pólvora ha dispuesto el tiempo; no se oyen allí más que golpes de barretas, picos y combas, acompañados con el canto triste de los indios; alli están todo el día y otros toda la noche, desnudos y batallando a fuerza de golpes de barretas y picos con la dureza de las piedras, sin sueño, mal comidos, azotados y en un continuo ahogo casi sin respiración. Puede aver mayor trabajo?. Mayor afan?. Mayor tormento?. No fué este el martirio que daban los țiranos a los confesores de Cristo y estos por el provecho de oro y plata?. Qué trabajo puede haber mayor?. Ya se vé si bien se considera. Y $Y$ que esto siendo preciso no tenga alivio! Téngalo, Señor, siquiera en que no paguen tributo $y$ ruego a V.S. se lo represente así $\alpha$ nuestro piadosísimo Rey y Señor.

48 Confirmo esta prueba con otra reflección más digna de cristianos, en lo que no se parece la mina al infierno; es que en este no ay muerte ni la puede aver para acabar con sus penas, pero la ay muy frecuente en las minas - ya por los derrumbes o ya porque faltando el ambiente se ahogan los miserables. Y ay con qué pagar la vida de los hombres?. Ni con qué compensar un peligro tan cierto de perderla?. Y quando aY quien entre a este peligro de muerte confesado, siendo muy prudencial que se entre las más veces en pecado mortal, con peligro de que con la muerte tan cierta pasen de aquel infierno temporal al eterno?. Y esto no se alivia?. No se compen. sa con el consuelo de que no paguen tributo? .

49 Pruebo lo $3^{\circ}$ esta misma parte. Aliviándose el tributo tendrá S.M. para sus minas reales muchísimos indios no sólo los forzados sina también voluntarios porque por redimirse de los Corregidores y los Caciques que los hostigan por las tributos vendrán a trabajar a millares los indios y más quando se les paga su trabajo como oy se paga en Guancavelica en plata, que los amos los tratan con agrado, pagan $y$ visten y como no tendrán que atender a otra pensión podrán cantar victoria de su desgracia y lograrán con contento sus jornales. Y qué alivio para un desdichado mayor que sólo tener un trabajo?. Es así que estos bienes les acarrea el no pagar tributos, luego es muy racional que no los paguen.

50 No digo que los que están destinados para la mita, esto es que los pueblos de mita y de Rosa no paguen del todo tributos sino que el qño que mitan y trabajan en el cerro no paguen. Con eso no caeró mucho la renta real ni seró mucho menos la baja desta. Pero por otra parte la recompensará Dios, así porque echará su divina mano muchas bendiciones ien esta piedad de nuestro Rey y hará que sus tesoros sean mucho mayores como por- 
que tendrá más indios que trabajen $\mathrm{y}$, por consiguiente avrá muchos más metales.

51 La $2^{\alpha}$ parte, esto es que los Corregidores no los pensionen en que trabajen sus obrajes e intereses la pruebo así. El mayor horror que tienen los. indios es de los Corregidores porquie fuera de lo que tengo largamente dicho en el Cap. 1 $1^{\circ}$ Núm. 23, muchos destos obligan a los indios a que trabajen sus obrajes, minas, intereses y les hacen crecidos repartimientos de géneros. de Castilla por precios muy subidos y aver de trabajar en las minas de $\mathbf{S}$. M. Y pagar tantas pensiones de Corregidores es cosa insoportablie a las fuerzas tan cortas destos pobres. O han de dar utilidad a los Corregidores o han de servir al Rey. Nadie puede servir a dos señores y menos estos infelices que son de tan débiles alientos y de los dos extremos sirvan a nuestro Monarca quis es señor común y tiene imperio en ellos y no a los Corregidores quei son Ministros particulares de justicia.

52 La $3^{a}$ parte que toca a los curas del Cerro pruebo. Viniendo los indios al pueblo del cerro y hallando allí en los curas amor, piedad y desinterés, tendrán por apetecible aquella estación. Una de las gravísimas cargas que tienen los indios son los curas, porque les pensionon en una continua cruz de cargas que yo no sé cómo pueden estos miserables hombres llevar tanto peso y así gimen y se hallan desesperados con tanto gravámen. No hablo de curas determinados sino de curas de indios en común. Desde que nacen son continuos pecheros dellos porque los bautismos cuestan plata y no ha faltado cura oue no ha querido bautizarlos hasta que aseguren los derechos. Los velorios, los entierros, las fiestas y cosas semejantes son a fuerza de plata obligándolos $\alpha$ que los pobres que no tienen que comer tengan en los entie rros de sus parientes misa de 4 ps. y al año honras, contra su voluntad, que llaman Mara Misa. S.M. les dá sínodo muy crecido y con el tienen bastantemente para su decencia y sustento y cuando no llevaran derechos $\alpha$ los indios por lo dicho, quedaban bien pagados pues muchos clérigos lo pasan con bastante decencia teniendo capellanías mucho más cortas. Este es uno de los medios que yo hallo para que Guancavelica se pueble de indios.

$53 \quad Y$ así se experimenta en Juli que es uno de los grandes pueblos que yo he visto en el Reyno y por ser tan grande lo llaman los indios en su idia ma Juli grande. Está en poder de los PP. de la Compañía y ha sido siem. pre asombro de todos los que lo ven y oyen lo que es. Quando se encargaron del los de la Compañía na llegaba con mucho a 100 vecinos y después ha tenido más de 12,000 familias. Y la razón de todo esto la dieron los curas vecinos al Sr. Conde de Lemos, quando estubo allí siendo Virrey del Perú, porque viendo tan desiertos los demás pueblos y tan colmado de gente $\alpha$ Juli les preguntó la causa de uno y otro y respondieron que porque los PP. de la Compañía no les llevaban obvenciones ni derechos por sus ministerios. Y dijo entonces S.E. que si fuera indio haría lo mismo, yéndose a vivir donde no tuviese pensiones. En Juli nada se recibe por misas, entierros, casamientos, bautismos y honras, porque todo se ejercita por caridad de que tengo experiencia cierta, contentóndose los 4 curas $\mathrm{y}$ ayudantes que viven en aquella residencia con 5,000 ps. que les dá S.M. en las cajas de Chucuifo y tienen con ellos para todo, sin que necesiten de otra cosa para la vida humana y religiosamente decente. Sean pues así los curas de los indios que vienen a Guancavelica y Potosí y verán la ansia con que vienen a servir a S.M. en sus reales minas y tomarán esta facena con gusto, viéndose aliviados por otra parte. Conspiren todos $\alpha$ los haberes de N. Rey zelando que se aumenten cada día, pero sin que se dejen llevar de intereses particu. lares y más siendo con tanta injusticia y falta de caridad con los indios. Pón- 
ganse en razón los Curas, Corregidores y españoles y vean que S.M. nos viste, nos alimenta, nos defiende dándonos minas con que todos tengan lo que han menester, disponiendo bajeles que vengan con tanta fatiga desde remotísimas distancias a estos términos del mundo para nuestros alivios. $Y$ lo que es más, aparta de sus distritos los enemigos de la fe y de la Iglesia por dejarnos limpio de ellos el camino del cielo. Lo qual sólo podemos pagar con servirle fielmente y hazer que los indios le sirvan con el amor correspondiente al que les tiene entrañable.

54 Lo demás que resta probar es notorio y no pidie más declaración que lo dicho. El Hospital pide siempre en Guancavelica grande zelo en Ios SS. Gobenuadores para que esté proveído de todo como oy para la cura de los indios enfermos. Es cisrto que parece ha resucitado el glorioso $\mathbf{S}$. Juan de Dios, según está oy servido de sus hijos, al fomento de V.S. que, según lo vemos, parece que no tiene más que hacer que cuidar del. La comida tan bien sazonada y a sus horas, las medicinas a tiempo, las salas reparadas, los canceles abrigados, las camas decentes. De que nace ir a él, en tiempo de V.S. tantos indios enfermos a curarse, viendo la frecuencia con que V. S. va al Hospital y lo cela, ya por su propia persona ya por diputados qua señala de los vecinos de la villa para que cuiden de los enfermos y de los religiosos, dando para todo su generosa piedad lo suficiente de dineros $\alpha$ proporción de las necesidades. Dios lo pagará asi en esta vida como en la otra, dando a V.S. y a sus hijos muchas felicidades.

55 Esto es lo que he podido decir, en esta materia tan grave en que si mo he dilatado ha sido forzoso para declarar la verdad de lo que sentía en mi conciencia. Ha sido preciso dividir la redacción en 3 capítulos, porque ya que me encargó V.S. hablase en Dios lo que sentía no podía decir menos de lo dicho. Ya veo que es materia digna de muy prolija consideración y que tendrá bastantemente punzada la real conciencia, sabiendo cómo tratan por acá a los pobres indios y quisieran sus amorosas entrañas poner remedio en esto, pero cómo es forzoso continuar la mita para que sus haberes no: descaezcan y florezca la Monarquía, mirando a Dios y al Rey he resuelto esto último, pareciéndome que así S.M. compondrá su conciencia y el que no se menoscabe su tesoro. Ruego a V.S. que este informe lo remita al Real Consejo para que ya que mi parecer no prevalezca, porque conozco que hombres más expertos, piadosos y doctos fundarán mejor que yo la resolución que se ha de tomar, a lo menos se sepa por allá lo que sin pasión alguna refiero y que realmente sucede con estos desgraciados indios, para que tanta lástima tenga remedio alguna vez, después que tanto se ha clamado, sin que en tantos años se haya moderado la exorbitante codicia de los Corregidores, sobre que tenía que dilatarme hasta formar un volumen crecido, según lo que he visto y entendido, levantando siempre mi corazón al Señor para que cese tiranía tan grande, que como particular no he podido significársela a S.M., por más que la he llorado hasta esta ocasión que V.S. ha fiado de mi insuficiencia, pero no podía decir menos de lo que he dicho. $Y$ vuelvo $\alpha$ repetir que en todo no he atendido a respetos humanos, porque nunca los he mirado sino a la razón, y por eso hablo con tanta claridad que quizá parecerá ofensiva, pero somos los sacerdotes, por obligación, luz del mundo $y$ a los que mal obran no podemos causar sino odio como amor a los que obran bien. Esto no es culpa de la luz sino de los que no se avienen con ella. Así lo siento y he trabajado por V.S. Y principalmente por N., Señor en este Colegio de Guancavelica oy 30 de Agosto de 1724._- Manuel de Toledo y Leiva. 